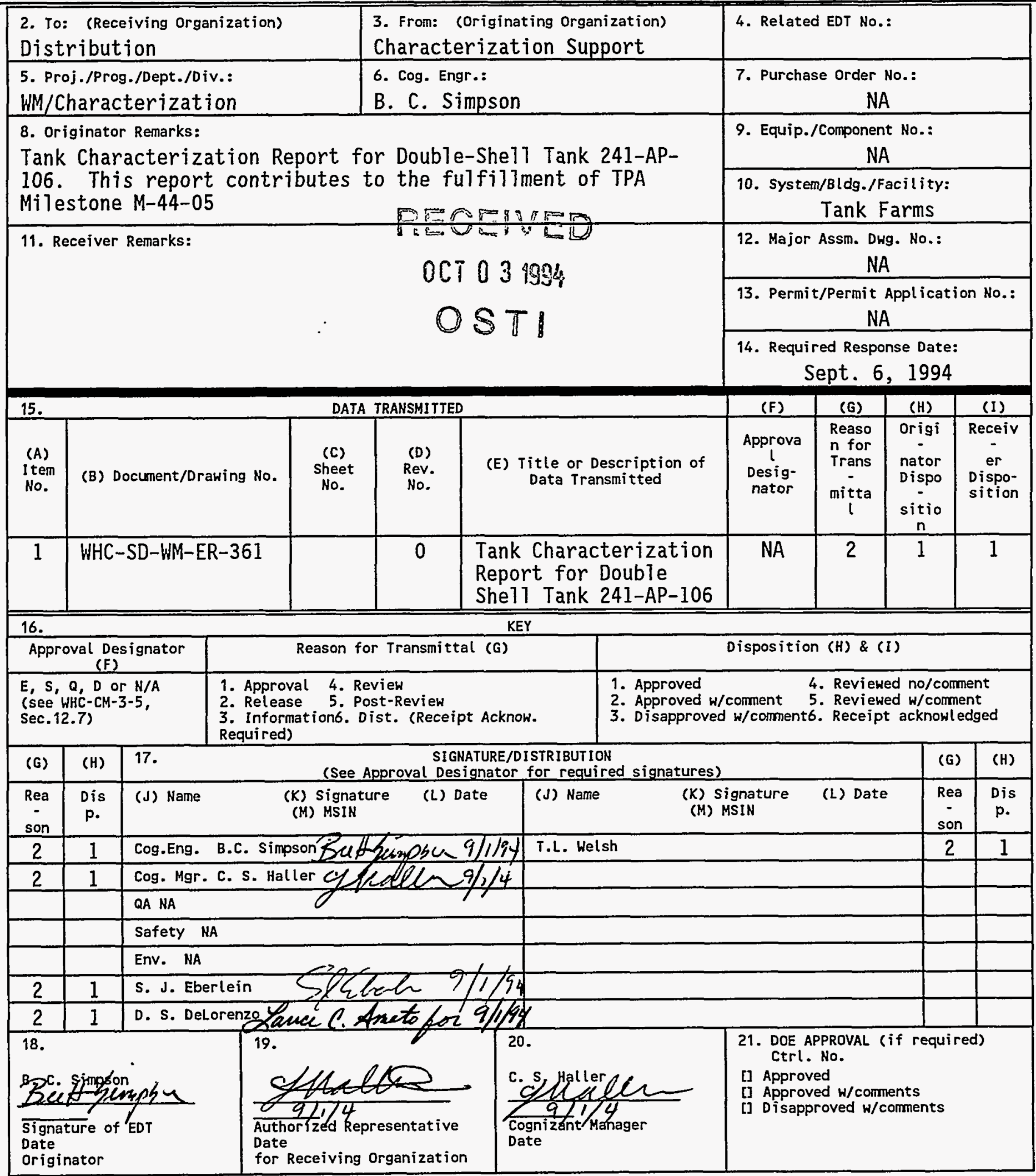

BD-7400-172-2 (04/94) GEF097 


\section{DISCLAIMER}

Portions of this document may be illegible in electronic image products. Images are produced from the best available original document. 


\section{RELEASE AUTHORIZATION}

Document Number: WHC-SD-WM-ER-361 REVISION 0

Document Title: Tank Characterization Report for Double-Shel1 Tank 241-AP-106

Release Date: $\quad 9 / 6 / 94$

This document was reviewed following the procedures described in WHC-CM-3-4 and is:

APPROVED FOR PUBLIC RELEASE

* * * * * * * * * * * *

WHC Information Release Administration Specialist:

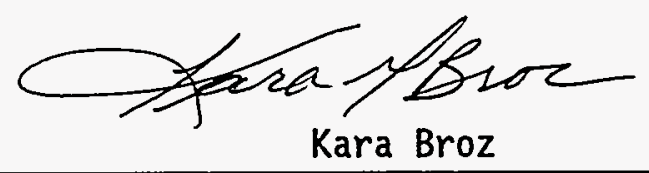

(Signature)
9/6/94

(Date) 
2. Title

Tank Characterization Report for Double-Shell Tank 241-AP-106

5. Key Words

3. Number

WHC-SD-WM-ER-361

4. Rev No.

0

Waste Characterization; Double-She11 Tank; AP-106; Name: D.S. DeLorenzo

Tank Characterization Report; Waste Inventory; AP

Farm; Grout Feed Tank; Grout Campaign 101; Grout

\section{APPROVED FOR}

6. Author

\section{PUBLIC RELEASE}

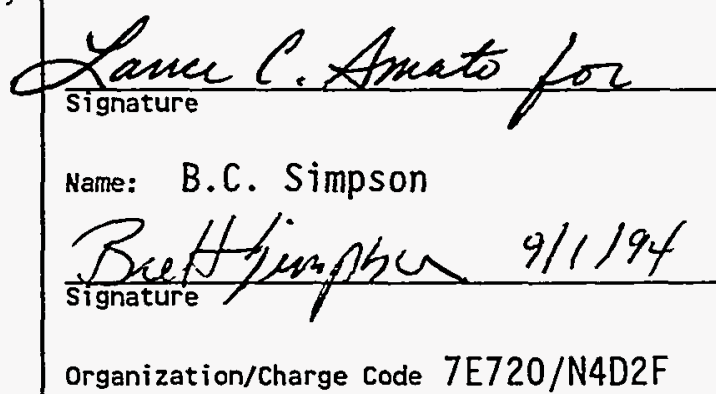

\section{Abstract}

This document provides the characterization information and interprets the data for Double-Shel1 Tank AP-106

8. RUIRPOSE AND USE OF DOCUMENT - This document was prepared for use withim the U.S. Department of Energy and its contractors. It is to be used only to perform, direct, or integrate work under U.S. Department of Energy contracts. This focument is not approved for public release until reviewed.

PATENT STATUS - This document Copy, since it is transmitted in advance of patent clearance, is made available in confidence solely for use in performence of work under contracts with the U.S. Department of Energy. This document is not tobe publ ished nor its contents otherwise disseminated or used for purposes ather than specified above before patent approval for such release or use has been secured, upon request, from the Patent Counsel, U.S. Department of Energy Field office, Richland, WA.

DISCLAIMER - This report was prepared as an account of work sponsored by an agency of the United States Government. Nej ther the United States Government nor any agency thereof, nor any of their employees, nor any of their contractors, subcontractors or their employees, makes any warranty, express or implied, or assumes any legal liability or responsibility for the accuracy, completeness, or any third party's use or the results of such use of any information, apparatus, product, or process disclosed, or represents that its use would not infringe privately owned rights. Reference herein to any specific commercial product, process, or service by trade name, trademark, manufacturer, or otherwise, does not necessarily constitute or imply its endorsement, recommendation, or favoring by the United States Government or any agency thereof or its contractors or subcontractors. The views and opinions of authors expressed herein do not necessarily state or reflect those of the United States Government or any agency thereof.

9. Impact Level NA
10. RELEASE STAMP

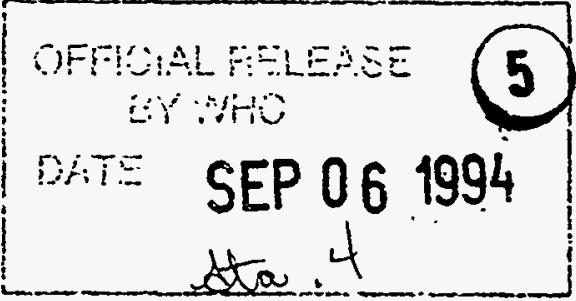




\title{
Tank Characterization Report for Double-Shell Tank 241-AP-106
}

\author{
D. S. De Lorenzo \\ A. T. DiCenso \\ L. C. Amato \\ R. H. Stephens \\ D. B. Hiller \\ Los Alamos Technical Associates, incorporated
}

B. C. Simpson

T. L. Welsh

Westinghouse Hanford Company

Date Published

August 1994

Prepared for Westinghouse Hanford Company by Los Alamos Technical Associates 8633 Gage Blvd.

Kennewick, WA 99336 


\section{EXECUTIVE SUMMARY}

Double-Shell Tank 241-AP-106 is a radioactive waste tank which was most recently sampled in March of 1993. Sampling and characterization of the waste in Tank 241-AP-106 contributes toward the fulfillment of Milestone M-44-05 of the Hanford Federal Facility Agreement and Consent Order.

Tank 241-AP-106 is located in the 200 East Area AP Tank Farm. It was constructed and went into service in 1986 as a dilute receiver tank; it later was considered as a candidate tank for the Grout Treatment Facility. Since the Grout Program has been canceled, the final disposal of the waste in Tank 241-AP-106 will be as highand low-level glass fractions. Tank 241-AP106 has an operational capacity of $1,140,000$ gallons and currently contains $1,128,000$ gallons of dilute non-complexed waste. All of the waste exists as an aqueous liquid. The tank is not classified as a Watch List tank and is considered to be sound. There are no Unreviewed Safety

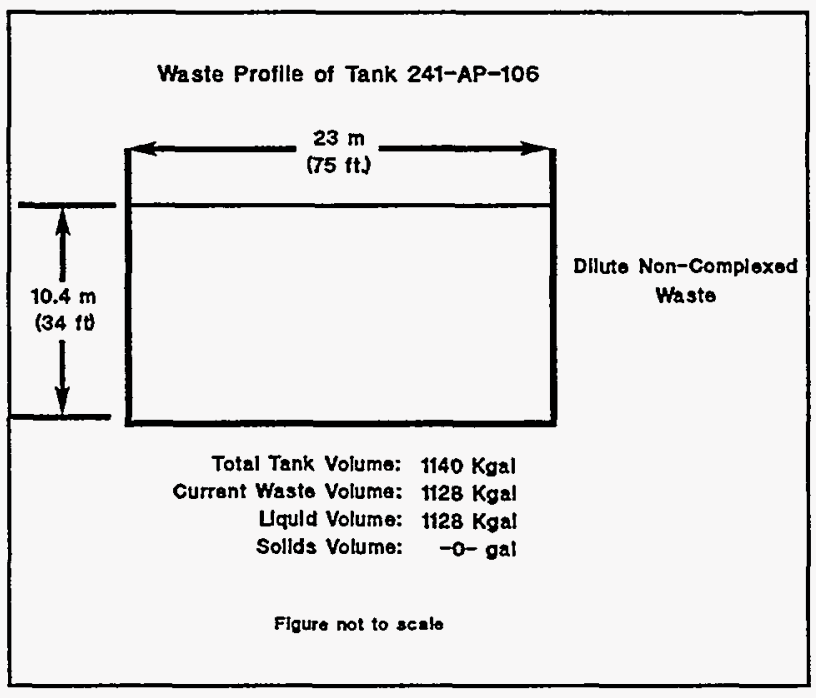
Questions associated with Tank 241-AP-106 at this time.

The waste in Tank 241-AP-106 exists as an aqueous solution of inorganic salts and radionuclides, with limited amounts of organic complexants. The most prevalent soluble analytes include aluminum, phosphorus, potassium, sodium, chloride, fluoride, hydroxide, nitrate, nitrite, phosphate, and sulfate. The calculated $\mathrm{pH}$ of 12.9 is above the Resource Conservation and Recovery Act established limit for corrosivity. In addition, cadmium was detected at levels greather than its regulatory threshold. The major radionuclide constituent is ${ }^{137} \mathrm{Cs}$, and the only organic complexants detected are glycolate and oxalate. Comparisons to established limits of concern for selected analytes can be made by referring to the Tank Characterization Reference Guide (De Lorenzo et al., 1994).

The results of the analyses have been compared to the dangerous waste codes in the Washington Dangerous Waste Regulations (WAC 173-303). This assessment was conducted by comparing tank analyses against dangerous waste characteristics (" $D$ " waste codes) and against state waste codes. It did not include checking tank analyses against " $U$ ", "P", " $F$ ", or "K" waste codes since application of these codes is dependent on the source of the waste and not on particular constituent concentrations. The results indicate that the waste in this tank is adequately described in the Dangerous Waste Permit Application for the Double-Shell Tank System; this permit is discussed in the Tank Characterization Reference Guide (De Lorenzo et al., 1994). 


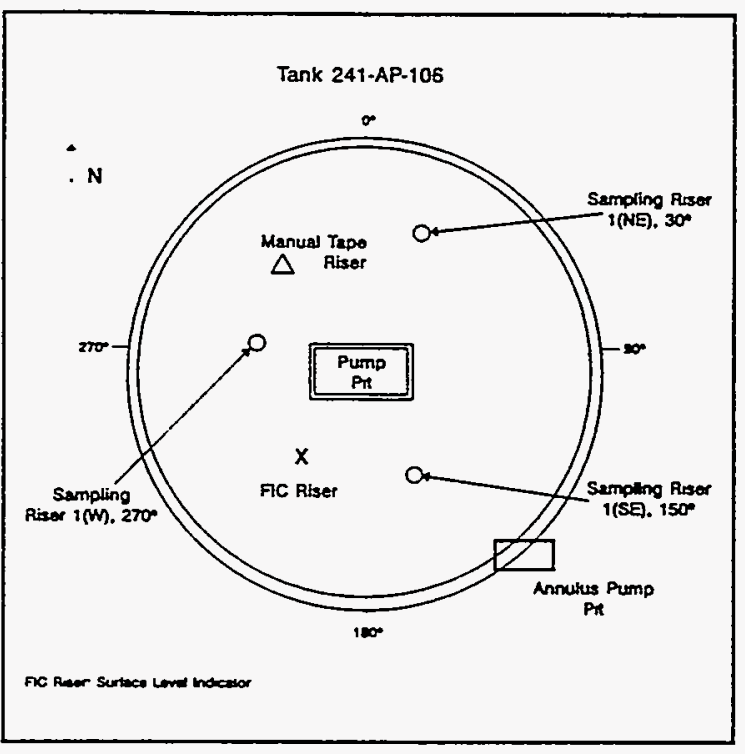

TANK 241-AP-106

Tank Description

Type:

Double-Shell

Constructed:

1986

In-Service:

1986

Diameter:

75 feet

Usable Depth:

35 feet

Operating Capacity:

$1,140,000$ gallons $(4,320,000 \mathrm{~L})$

Bottom Shape:

Flat

Hanford Coordinates:

$40.393^{\circ}$ North

$46.968^{\circ}$ West

Ventilation:

Operating Exhauster

Tank Status: as of May 1994

Contents:

Dilute NonComplexed Waste

Total Waste:

$1,128,000$ gallons $(4,270,000 \mathrm{~L})$

$(4,280,000 \mathrm{~kg})$

Liquid Volume:

$1,128,000$ gallons

$(4,270,000 \mathrm{~L})$

$(4,280,000 \mathrm{~kg})$

Drainable Interstitial

Liquid:

-0- gallons

Manual Tape Surface

Level:

410 inches (5/2/94)

FIC Surface Level:

409.2 inches

(5/2/94)

Temperature:

$66^{\circ} \mathrm{F}(5 / 2 / 94)$

Integrity Category:

\begin{tabular}{|c|c|c|}
\hline \multicolumn{3}{|c|}{$\begin{array}{l}\text { Double-Shell Tank 241-AP-106 Concentrations and } \\
\text { Inventories for Critical List Analytes (as of May 1994) }\end{array}$} \\
\hline \multicolumn{3}{|l|}{ Physical Properties } \\
\hline Specific Gravity & \multicolumn{2}{|c|}{0.996} \\
\hline $\mathrm{H}_{2} \mathrm{O}$ & \multicolumn{2}{|c|}{100.2 wt \% } \\
\hline $\mathrm{pH}$ & \multicolumn{2}{|c|}{12.9} \\
\hline Heat Load & \multicolumn{2}{|c|}{$<97.3 w$} \\
\hline Chemical Constituents & Average Concentration & Bulk inventory \\
\hline Al (Aluminum) & 0.0211 wt \% & $901 \mathrm{~kg}$ \\
\hline Cr (Chromium) & 4.72 E-04 wt \% & $20.2 \mathrm{~kg}$ \\
\hline P (Phosphorus) & 8.51 E.03 wt \% & $364 \mathrm{~kg}$ \\
\hline $\mathrm{K}$ (Potassium) & 0.0815 & $3,490 \mathrm{~kg}$ \\
\hline $\mathrm{Na}$ (Sodium) & 0.552 wt \% & $23,600 \mathrm{~kg}$ \\
\hline $\mathrm{Cl}^{-}$(Chloride) & 5.16 E.03 wt \% & $240 \mathrm{~kg}$ \\
\hline $\mathrm{CN}^{-}$(Cyanide) & 5.05 E-05 wr \% & $2.15 \mathrm{~kg}$ \\
\hline$F \cdot$ (Fluoride) & $0.0173 w \tau \%$ & $739 \mathrm{~kg}$ \\
\hline $\mathrm{OH}^{-}$(Hydroxide) & 0.143 wt \% & $6.110 \mathrm{~kg}$ \\
\hline $\mathrm{NO}_{3}^{*}$ (Nitrate) & $0.423 w t \%$ & $18,100 \mathrm{~kg}$ \\
\hline $\mathrm{NO}_{2}^{-}$(Nitrite) & 0.117 wt \% & $4,970 \mathrm{~kg}$ \\
\hline $\mathrm{PO}_{4}^{3-}$ (Phosphate) & 0.0211 wt \% & $901 \mathrm{~kg}$ \\
\hline $\mathrm{SO}_{4}^{2-}$ (Sulfate) & 0.0140 wt \% & $598 \mathrm{~kg}$ \\
\hline Total Inorganic Carbon & 0.0486 wt \% & $2,080 \mathrm{~kg}$ \\
\hline Total Organic Carbon & 0.0495 wt \% & $2,120 \mathrm{~kg}$ \\
\hline Glycolate & 6.42 E.03 wt \% & $275 \mathrm{~kg}$ \\
\hline Oxalate & 7.54 E-03 wt $\%$ & $323 \mathrm{~kg}$ \\
\hline \multicolumn{3}{|l|}{ Radionuclides } \\
\hline${ }^{134} \mathrm{Cs}$ & $12.6 \mu \mathrm{Ci} / \mathrm{L}$ & $53.8 \mathrm{Ci}$ \\
\hline${ }^{137} \mathrm{Cs}$ & $4,570 \mu \mathrm{Ci} / \mathrm{L}$ & $19,500 \mathrm{Ci}$ \\
\hline Total Plutonium & $<0.368 \mu \mathrm{Ci} / \mathrm{L}$ & $<1.57 \mathrm{Ci}$ \\
\hline${ }^{90} \mathrm{Sr}$ & $0.698 \mu \mathrm{Ci} / \mathrm{L}$ & $2.98 \mathrm{Ci}$ \\
\hline${ }^{99} \mathrm{TC}$ & $1.34 \mu \mathrm{Ci} / \mathrm{L}$ & $5.72 \mathrm{Ci}$ \\
\hline${ }^{3} \mathrm{H}$ & $4.90 \mu \mathrm{Ci} / \mathrm{L}$ & $20.9 \mathrm{Ci}$ \\
\hline Total Uranium & 3.71 E.04 wt \% & $15.8 \mathrm{~kg}$ \\
\hline
\end{tabular}




\section{CONTENTS}

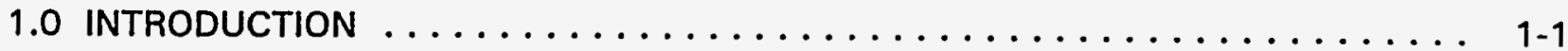

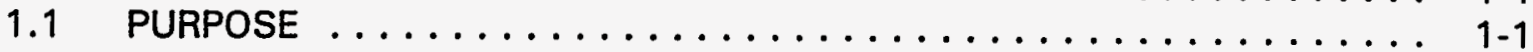

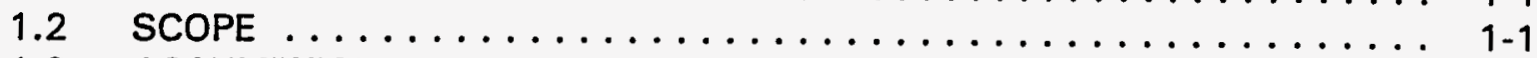

1.3 ASSUMPTIONS ..........................

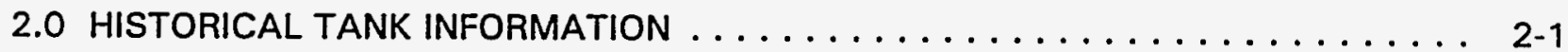

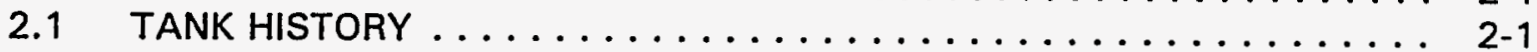

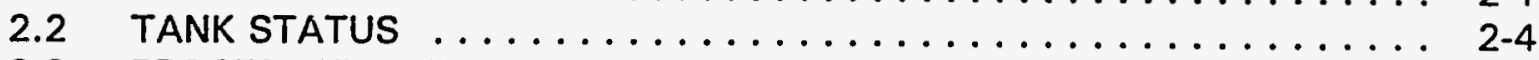

2.3 PROCESS KNOWLEDGE $\ldots \ldots \ldots \ldots \ldots \ldots \ldots \ldots \ldots \ldots \ldots \ldots \ldots \ldots . \ldots \ldots$

2.4 HISTORICAL ESTIMATION OF THE CONTENTS OF TANK 241-AP-106 . 2-6

2.5 SURVEILLANCE DATA ..................... 2-6

2.5.1 Surface Level Readings ................... 2-6

2.5.2 Internal Tank Temperatures ................. 2-7

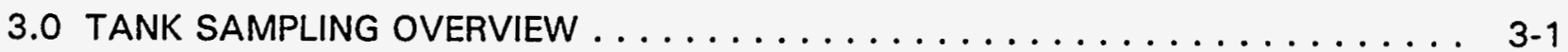

3.1 DESCRIPTION OF SAMPLING EVENT $\ldots \ldots \ldots \ldots \ldots \ldots \ldots \ldots \ldots \ldots$

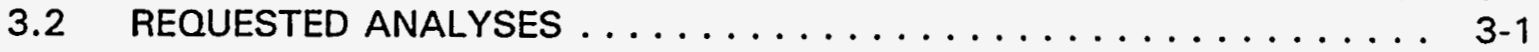

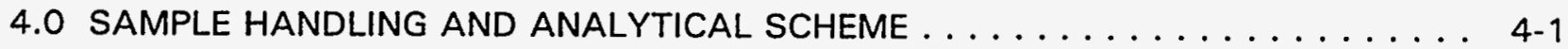

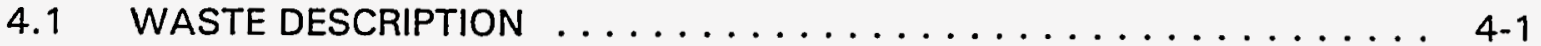

4.2 HOLD TIME CONSIDERATIONS ................... 4-1

4.2.1 WHC - Processing and Analytical Laboratories . . . . . . . . . . 4 4-1

4.2.2 Pacific Northwest Laboratory - Analytical Chemistry Laboratory . . . 4-1

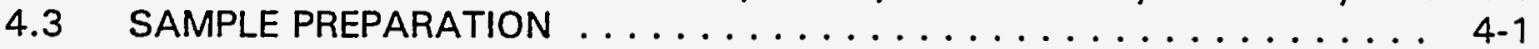

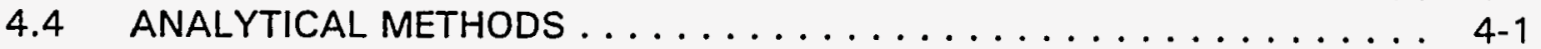

4.4.1 Physical Tests ....................... 4-3

4.4 .2 Homogeneity of Waste . . . . . . . . . . . . . . 4-3

4.4.3 Chemical and Radionuclide Constituent Analysis .......... . 4-3

4.4.4 Volatile and Semivolatile Organic Constituent Analysis . . . . . . . . 4-3

4.4 .5 Grout Product Tests . . . . . . . . . . . . . . . . . . . 4-4

4.5 MODULE SPECIFIC ANALYSES $\ldots \ldots \ldots \ldots \ldots \ldots \ldots \ldots \ldots \ldots$

5.0 ANALYTICAL RESULTS AND WASTE INVENTORY $\ldots \ldots \ldots \ldots \ldots \ldots \ldots$

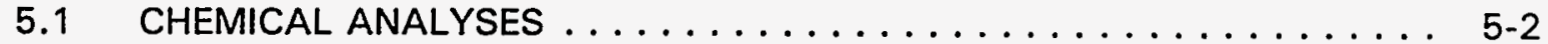

5.1 .1 Elemental Constituents ..................... $5-2$

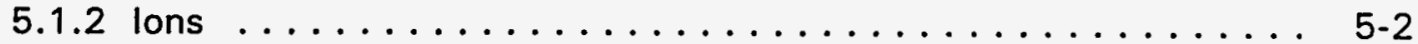

5.2 RADIOLOGICAL DETERMINATIONS $\ldots \ldots \ldots \ldots \ldots \ldots \ldots \ldots \ldots \ldots$

5.3 ORGANIC CONSTITUENTS $\ldots \ldots \ldots \ldots \ldots \ldots \ldots \ldots \ldots \ldots \ldots$

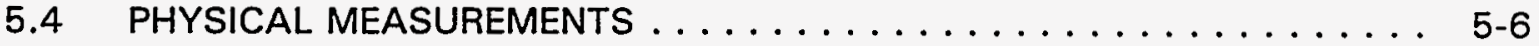

5.4.1 Percent Water and Specific Gravity . . . . . . . . . . . . . . . . 5-6 . . . . . . . . . . . . .

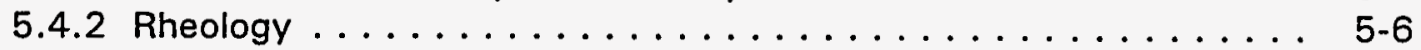

5.4 .3 Energetics ........................ 5-7

5.5 DATA PRESENTATION $\ldots \ldots \ldots \ldots \ldots \ldots \ldots \ldots \ldots \ldots \ldots \ldots \ldots \ldots$ 
CONTENTS (continued)

6.0 ANALYTICAL RESULTS INTERPRETATION . . . . . . . . . . . . . . 6-1

6.1 TANK WASTE PROFILE . . . . . . . . . . . . . . . . . 6 6-1

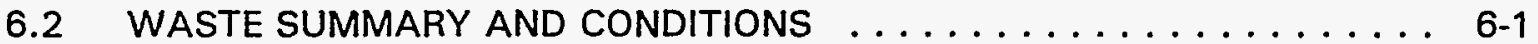

6.2 .1 Projected Tank Heat Load .................... 6-1

6.2 .2 Regulatory Limits . . . . . . . . . . . . . . . . 6-1

6.3 PROGRAM ELEMENT SPECIFIC ANALYSES $\ldots \ldots \ldots \ldots \ldots \ldots \ldots \ldots \ldots$

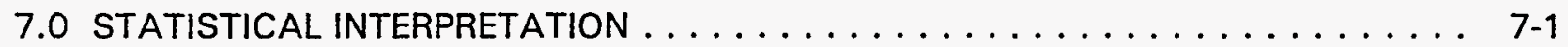

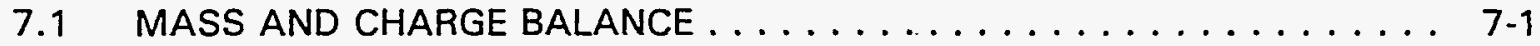

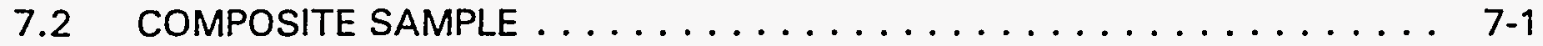

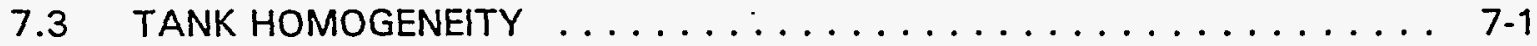

7.4 ANALYTICAL ERROR ESTIMATION $\ldots \ldots \ldots \ldots \ldots \ldots \ldots \ldots \ldots \ldots$

8.0 CONCLUSIONS AND RECOMMENDATIONS $\ldots \ldots \ldots \ldots \ldots \ldots \ldots \ldots \ldots$

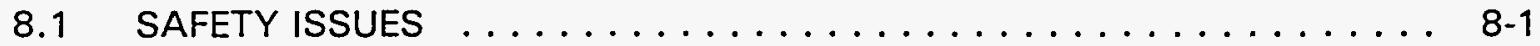

8.2 FURTHER CHARACTERIZATION NEEDS $\ldots \ldots \ldots \ldots \ldots \ldots \ldots \ldots$

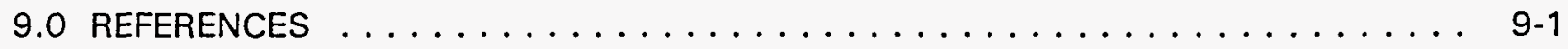

APPENDIX A ANALYTICAL RESULTS $\ldots \ldots \ldots \ldots \ldots \ldots \ldots \ldots \ldots \ldots$

LIST OF FIGURES

2-1. Double-Shell Tank Configuration $\ldots \ldots \ldots \ldots \ldots \ldots \ldots \ldots \ldots \ldots \ldots \ldots$

2-2. Location of the 241 -AP Tank Farm . . . . . . . . . . . . . $2-3$

2-3. Waste Volume History of Tank $241-$ AP-106 . . . . . . . . . . . 2-5

2-4. Thermocouple Tree Raw Temperature Plot for Tank 241-AP-106 . . . . . . . . 2-8

3-1. Tank 241-AP-106 Sample Locations and Tank Farm Numbers . . . . . . . . . 3-2

5-2. Tank 241-AP-106 Analytical Data ................... 5-3 
WHC-SD-WM-ER-361 REV O

\section{LIST OF TABLES}

2-1. Estimated Waste Composition of Tank 241-AP-106 . . . . . . . . . . . 2-6

3-1. WHC Sample Numbers for Tank $241-A P-106 \ldots \ldots \ldots \ldots \ldots$

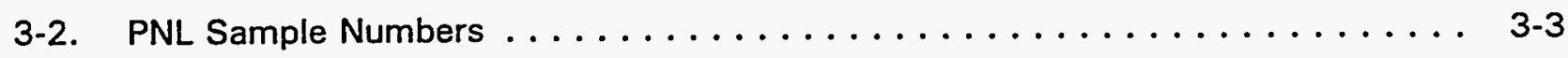

3-3. Tank 241-AP-106 Samples and the Analytes Evaluated . . . . . . . . . . . 3-4

4-1. Analytical Methods ........................... 4-2

5-1. Analytical Data Presentation Tables .................... 5-1

6-1. Tank 241-AP-106 Projected Heat Load . . . . . . . . . . . . . . . . . 6-2

6-2. Applicability of Characterization Information to the Data Needs of the TWRS Program Elements .......................... $6-3$

7-1. Tank 241-AP-106 Mass/Charge Balance . . . . . . . . . . . . . . . 7-2

7-2. Measurement Error Estimates $\ldots \ldots \ldots \ldots \ldots \ldots \ldots \ldots \ldots \ldots \ldots$ 


\section{LIST OF TERMS}

$\begin{array}{ll}\text { CASS } & \text { Computer Automated Surveillance System } \\ \text { CFR } & \text { Code of Federal Regulations } \\ \text { CLP } & \text { Contract Laboratory Program } \\ \text { DNFSB } & \text { Defense Nuclear Facilities Safety Board } \\ \text { DOE } & \text { United States Department of Energy } \\ \text { EPA } & \text { United States Environmental Protection Agency } \\ \text { FIC } & \text { Food Instrument Corporation } \\ \text { MDL } & \text { method detection limit } \\ \text { PNL } & \text { Pacific Northwest Laboratory } \\ \text { PUREX } & \text { Plutonium-Uranium Extraction Plant } \\ \text { QC } & \text { quality control } \\ \text { RCRA } & \text { Resource Conservation and Recovery Act } \\ \text { RPD } & \text { relative percent difference } \\ \text { SOW } & \text { statement of work } \\ \text { SST } & \text { single-shell tank } \\ \text { TBP } & \text { tributyl phosphate } \\ \text { TCLP } & \text { toxicity characteristic leaching procedure } \\ \text { TPP } & \text { technical project plan } \\ \text { TWRS } & \text { Tank Waste Remediation System } \\ \text { USO } & \text { unreviewed safety question } \\ \text { WHC } & \text { Westinghouse Hanford Company }\end{array}$




\subsection{INTRODUCTION}

In March 1993, Double-Shell Tank 241-AP-106 was sampled to determine waste feed characteristics for the Hanford Grout Disposal Program. This Tank Characterization Report presents an overview of that tank sampling and analysis effort, and contains observations regarding waste characteristics, expected inventory, and concentration data for the waste contents based on this latest sampling data and information on the history of the tank. Finally, this report makes recommendations and conclusions regarding tank operational safety issues.

\subsection{PURPOSE}

The purpose of this Tank Characterization Report is to describe and characterize the waste in Double-Shell Tank 241-AP-106 (hereafter Tank 241-AP-106) based on information given from various sources. This report summarizes the available information, and arranges it in a useful format for making management and technical decisions concerning this particular waste tank. In addition, conclusions and recommendations based on safety issues and further characterization needs are given. This report presents a comprehensive overview of the material in Tank 241-AP-106. Specific objectives reached by the sampling and characterization of the waste in Tank 241-AP-106 are:

- $\quad$ Contribute towards the fulfillment of the Hanford Federal Facility Agreement and Consent Order (Tri-Party Agreement) Milestone M-44-05 concerning the characterization of Hanford Site high-level radioactive waste tanks (Ecology, EPA and DOE, 1993).

- Complete safety screening of the contents of Tank 241-AP-106 to meet the characterization requirements of the Defense Nuclear Facilities Safety Board (DNFSB) Recommendation 93-5 (Conway, 1993).

- Provide tank waste characterization to the Tank Waste Remediation System (TWRS) Program Elements in accordance with the TWRS Tank Waste Analysis Plan (Bell, 1994).

\subsection{SCOPE}

First, this report presents a broad background of historical information that was available prior to the sampling activity. The result of this review is the detailed estimation of the contents of Tank 241-AP-106 based on historical process information and detailed transaction records. Next, the results of the sampling and analysis effort are summarized, and interpreted both qualitatively and quantitatively. The information obtained from historical sources is then compared with the actual waste measurements to arrive at final waste inventory and concentration estimates. Finally, conclusions and recommendations are given based on the current waste inventory and tank status. 


\subsection{ASSUMPTIONS}

The concentration and inventory estimates derived for this report are considered by the authors and by the Westinghouse Hanford Company Characterization Program to be the most accurate, defensible, technically valid, and contemporary data concerning Tank 241-AP-106. This Tank Characterization Report incorporates all available previous sampling, characterization, and transfer data concerning Tank 241-AP-106. In addition, estimates of the current tank contents based on process knowledge and waste transaction records provide important cross-checks and corroboration to the inventory estimates derived from recent analytical data. Based on the statistical determination that the tank waste is homogeneous, and given that the analytical data is valid and defensible, this report is therefore the definitive characterization of the contents of Tank 241-AP-106.

The term "analytical results" is used in this report to denote sample results from the most recent sampling event, the characterization of Tank 241-AP-106 waste for the Hanford Grout Disposal Program. Characterization data from these samples are used for the analytical section of this report, Section 5. The historical characterization of this tank, Section 2.4 , is based on the available historical results prior to the 1993 grout sampling.

Tank 241-AP-106 remains in active service for waste management operations. Although the future contents of the tank will likely change, the characterization of Tank 241 AP-106 is considered accurate and representative of the tank contents as of the date of preparation of this report: August, 1994. 


\subsection{HISTORICAL TANK INFORMATION}

The purpose of this section is to describe Tank 241-AP-106 based on historical tank information; it is divided into six parts. A brief description and historical background of the tank comprise the first two parts, followed by current tank status, a summary of the process sources that contributed to the tank waste, and an estimation of the contents of Tank 241 AP-106 based on historical information. The final part details surveillance data taken on the tank.

\subsection{TANK HISTORY}

Tank 241-AP-106 is a tank-in-tank design consisting of a heat-treated primary steel liner, inside a second steel liner. The primary tank has a design capacity for storing 1.16 million gallons of waste; however, safety considerations require a maximum operating capacity of 1.14 million gallons. Instruments access Tank 241-AP-106 through risers and monitor the pressure, temperature, liquid level, sludge level, and other tank characteristics (Bell, 1994). Figure 2-1 presents a detailed diagram of a double-shell tank (Hanlon, 1994).

Tank 241-AP-106 was constructed and went into service in 1986 as a Dilute Receiver Tank. It is one of eight tanks that comprise the 241-AP Tank Farm located in the southeast corner of the 200 East Area. Figure 2-2 shows the location of the AP Tank Farm. This particular tank is located in the Tank Farm's east row and is one tank up from the south end.

Tank 241-AP-106 is a 1.14 million gallon radioactive waste tank containing only dilute non-complexed waste primarily from two sources. Most of the current tank waste (approximately $80 \%$ ) was transferred from Tank 241-AY-102. Other sources of waste are the 242-A Evaporator by way of Tank 241-AW-106, and a small amount of flush water. Tank 241-AP-106 contents were removed in 1989 for evaporation and concentration and later returned. These transfers are detailed in Section 2.4 .

In 1992 the contents of Tank 241-AP-106 were selected as candidate waste to be blended with concentrated waste from other tanks for processing and disposal at the Hanford Grout Treatment Facility (Hendrickson and Welsh, 1992). However, the Grout Program was canceled one year later. Grout treatment was originally planned as one of the processes for the environmental remediation of the waste tanks. It involved mixing selected low-level, double-shell tank waste (inorganic salt/water mixtures) with grout forming solids. The resulting grout slurry was to be pumped to near-surface concrete vaults for solidification and permanent disposal. With the program's cancellation, the final disposal of all tank wastes will be through the Hanford Waste Vitrification Plant as high- and low-level glass fractions. 
Figure 2-1. Double-Shell Tank Configuration.

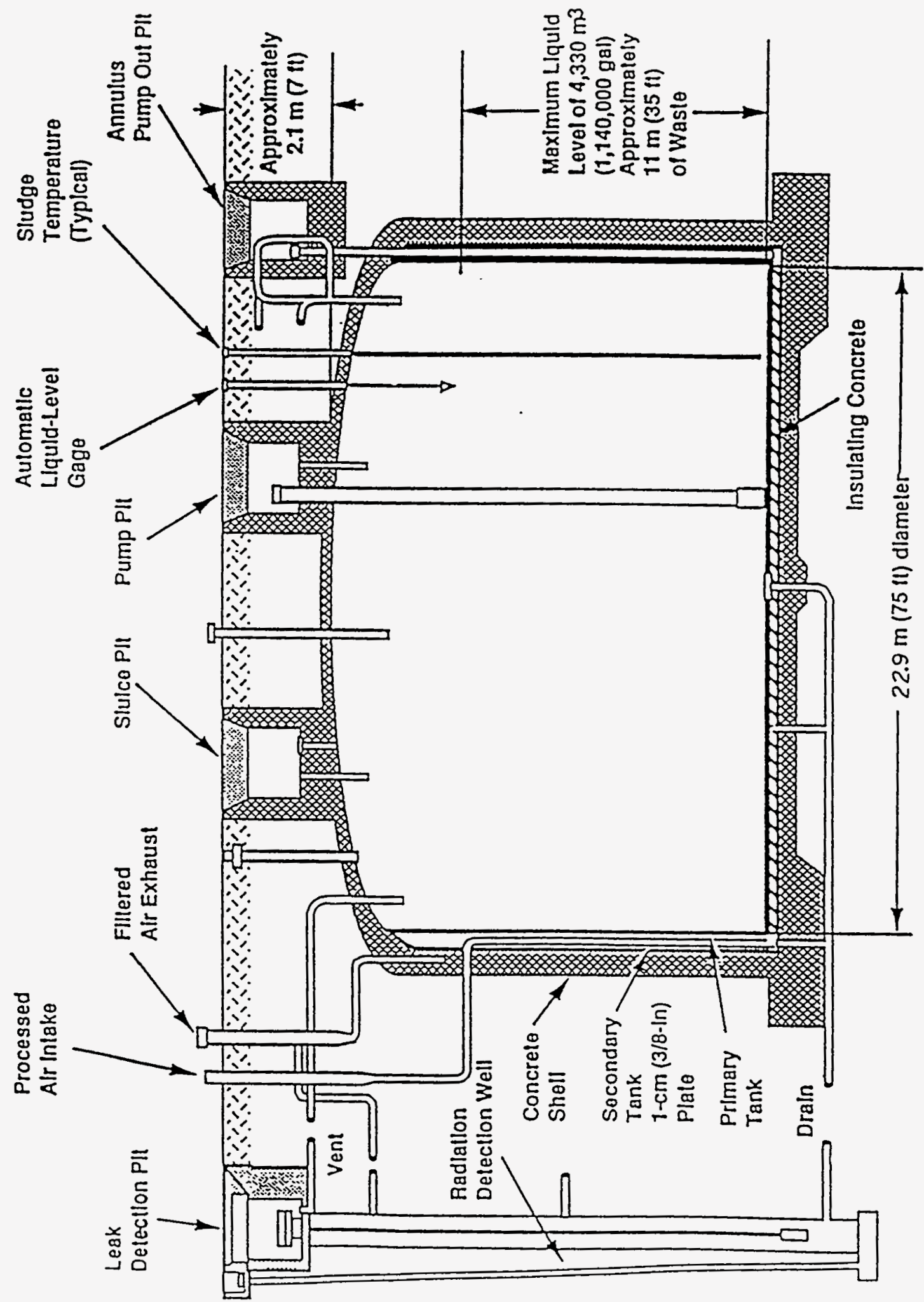


Figure 2-2. Location of the 241-AP Tank Farm.

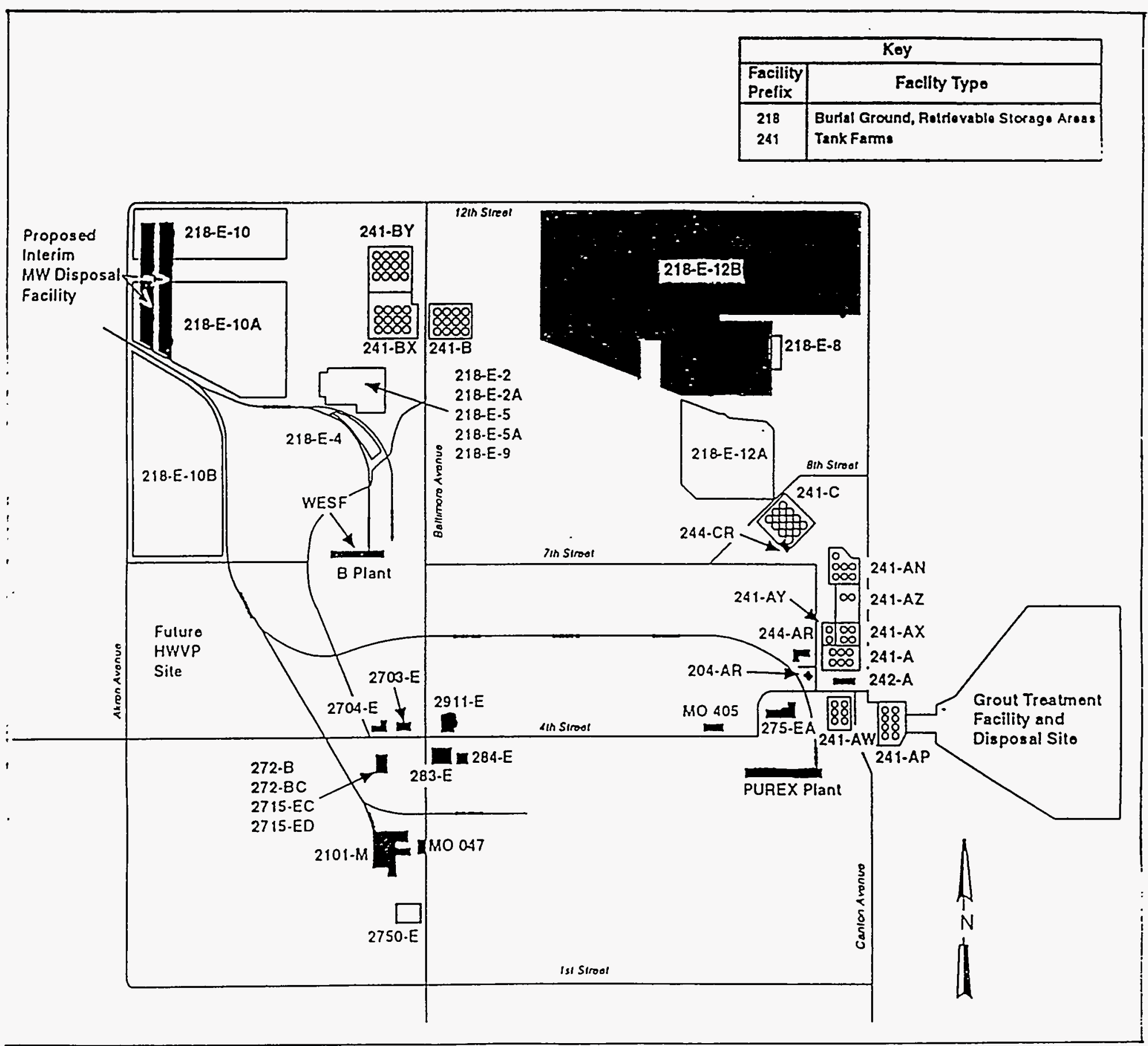


WHC-SD-WM-ER-361 REV 0

\subsection{TANK STATUS}

Tank 241-AP-106 presently contains 1,128,000 gallons of dilute non-complex waste. The tank is at $99 \%$ capacity (volume) with 12,000 gallons of reserve capacity. Tank 241-AP106 is still in service, as are all eight tanks in the AP Tank Farm. The "in-service" designation allows these tanks to continue receiving liquid in conjunction with production and/or waste processing operations. The tank integrity is classified as sound and it is not currently on any Watch List. There are no Unreviewed Safety Questions associated with Tank 241-AP-106 at this time (Hanlon, 1994).

Tank 241-AP-106 is equipped with both a manual tape and an automated liquid indicator device for surface level readings; both are still operable. The waste occupies approximately the bottom 410 inches of the tank. All tank instruments, with the exception of the Leak Detection Pit radiation detector, are in monitoring compliance (Hanlon, 1994). The tank's temperatures are stable, with $66^{\circ} \mathrm{F}$ reported on May 2, 1994.

The tank contents are believed to be homogeneous (see Sections 7.2 and 7.3 for further discussions of tank homogeneity). Active ventilation through a filtration system is used to keep the tank contents cool and minimize the potential release of airborne contaminants to the environment (Husa et al, 1993).

\subsection{PROCESS KNOWLEDGE}

Figure 2-3 depicts the fill history of Tank 241-AP-106 from when it became operational in August 1986, to the end of the fourth quarter 1993, the last entry in the Waste Volume Projection Historical Database (Koreski, 1994). A detailed description of the transfers responsible for these waste level fluctuations follows. All of the volume data were taken from the Waste Volume Projection Historical Database.

Tank 241-AP-106 entered service with the introduction of 19,000 gallons of flush water in August 1986. In July 1988, the tank received 275,000 gallons of dilute noncomplex waste from the 242-A Evaporator by way of Tank 241-AW-106. Another 289,000 gallons were received from the same source in August. Only one additional transaction occurred during the remainder of 1988 as 3,000 gallons of waste were sent from Tank 241AP-106 to the Hanford Grout Treatment Facility in September.

The entire contents of the tank, 580,000 gallons, were sent to the 242-A Evaporator in February 1989; 490,000 gallons were returned for a volume reduction of approximately $20 \%$. Tank $241-$ AP-106 ended the first quarter of $198943 \%$ full.

In July 1989, Tank 241-AP-106 received 83,000 gallons of dilute non-complexed supernate from Tank 241-AW-106. Also, 355,000 gallons of waste were transferred from Tank 241-AP-106 to Tank 241-AP-105. In late July, the tank received its largest transfer; 709,000 gallons of supernate were transferred from Tank 241-AY-102 raising the total waste volume in Tank 241-AP-106 to 927,000 gallons. At the time of transfer, Tank 241-AY-102 contained mostly B-Plant Vessel Clean-Out and B-Plant Strontium Processing wastes. Then in October, Tank 241-AP-106 received another 214,000 gallons from Tank 241-AY-102. The waste sources of Tank 241-AY-102 had changed considerably since the earlier transfer with the addition of waste from Tank 241-SY-102. 
Figure 2-3. Waste Volume History of Tank 241-AP-106.

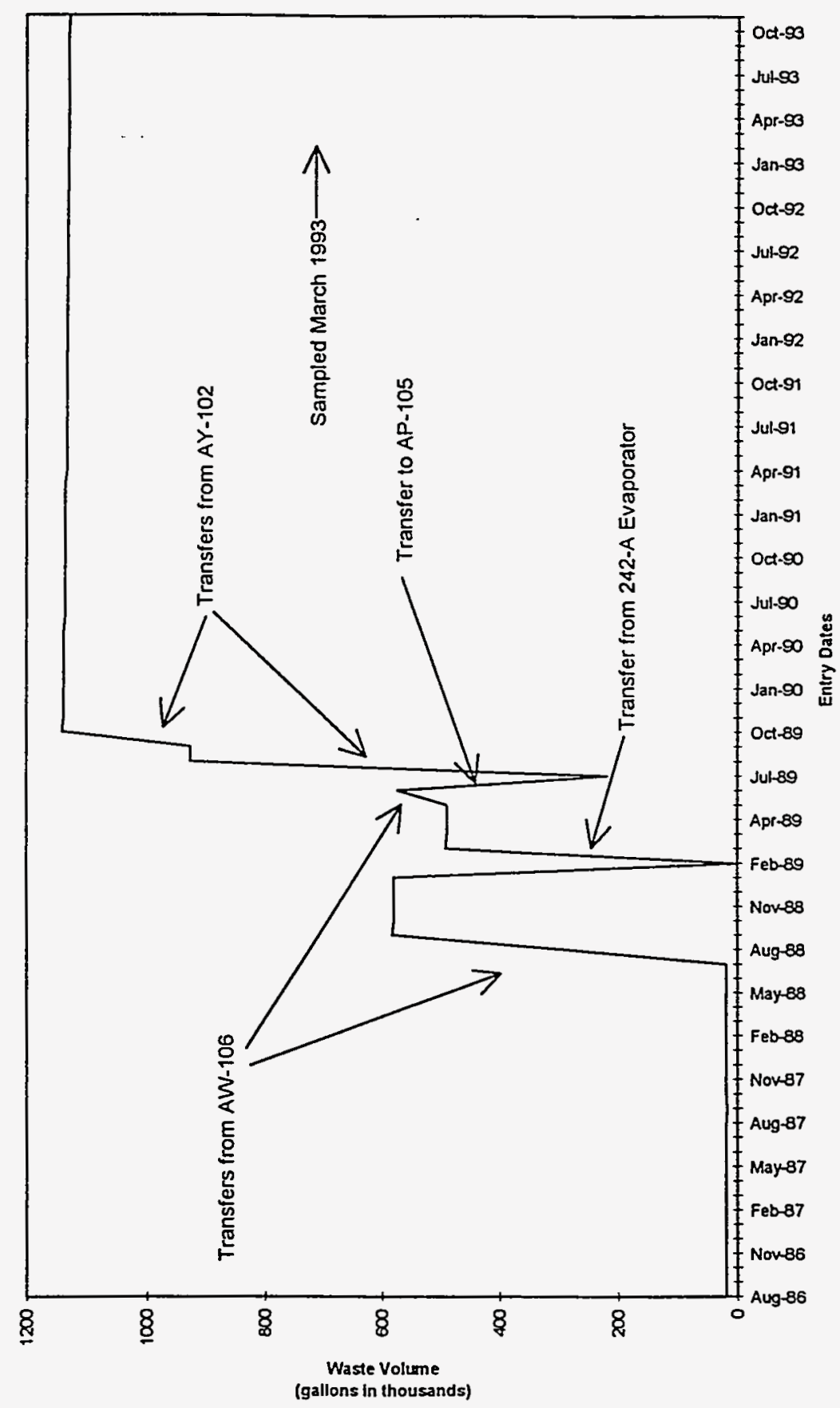


With the October transfer, Tank 241-AP-106 reached its peak waste volume of $1,141,000$ gallons, slightly beyond it's maximum operating capacity but still below the original design capacity. Small unknown losses since then have lowered the waste volume to $99 \%$ of capacity. Unknown losses are most likely caused by evaporation. Losses or gains due to instrumentation also account for changes in tank volume. A switch from one measurement to another would be recorded as a gain or loss in depth since the methods do not have the same reference zero. An example of this is changing from the automated liquid level indicator to manual tape. If the tank volume calculation for Tank 241-AP-106 was changed today from automatic to manual tape, a gain of about 2,200 would result since the difference between the measured FIC level and the manual tape level is 0.80 inches $(2,750$ gallons per inch). The current volume for the tank was reported at $1,128,000$ gallons following a loss of 13,000 gallons over four years. This gradual and constant decline in waste level represents a loss of approximately nine gallons per day, an amount likely attributable to evaporation from the waste's surface.

\subsection{HISTORICAL ESTIMATION OF THE CONTENTS OF TANK 241-AP-106}

A preliminary estimate of the current waste constituents of Tank 241-AP-106 can be made based on transfer history and waste stream analyses. This estimate is useful as a baseline for comparison with the latest tank sampling data, and is presented in Table 2-1. This estimate also appears as the Historic Tank Content Estimate in Table 5-2. All historical values were taken from Hendrickson and Welsh (1992), Section 4.0. The methodology for determining these constituent values is contained in Appendix A of Hendrickson and Welsh.

Table 2-1. Estimated Waste Composition of Tank 241-AP-106.

\begin{tabular}{|c|c|}
\hline Constituent & Estimated Concentration \\
\hline $\mathrm{TOC}$ & $0.51 \mathrm{~g} / \mathrm{L}$ \\
\hline $\mathrm{NO}_{2}$ & $4.96 \mathrm{~g} / \mathrm{L}$ \\
\hline $\mathrm{NO}_{3}$ & $9.54 \mathrm{~g} / \mathrm{L}$ \\
\hline $\mathrm{Na}$ & $23.92 \mathrm{~g} / \mathrm{L}$ \\
\hline${ }^{90} \mathrm{Sr}$ & $4,205 \mu \mathrm{Ci} / \mathrm{L}$ \\
\hline${ }^{137} \mathrm{Cs}$ & $35,980 \mu \mathrm{Ci} / \mathrm{L}$ \\
\hline
\end{tabular}

\subsection{SURVEILLANCE DATA}

\subsubsection{Surface Level Readings}

Tank 241-AP-106 is equipped with a liquid level gauge manufactured by the Food Instrument Corporation (FIC) which can be monitored either automatically or manually. The FIC indicator uses a conductivity probe to detect the level of the tank's contents and, in the automatic mode, is electrically connected to a computer for data transmission via the Computer Automated Surveillance System (CASS). Tank 241-AP-106 is also equipped with a manual tape, from which readings are taken when the FIC indicator is out of service. Both devices are currently operable. The most recent FIC liquid level measurement available was 
409.2 inches on May 2, 1994 (Rios, 1994). The manual tape reading for the same date was 410 inches. This small difference $(0.80$ inches) represents a relative percent difference of only $0.2 \%$.

\subsubsection{Internal Tank Temperatures}

Tank 241-AP-106, as well as all other AP Tank Farm double-shell tanks, is equipped with approximately 100 thermocouples (thermoelectric temperature measuring devices) in the tank interior, the annular space, and in the concrete outer shell. A thermocouple tree, with 18 thermocouples assembled in a pipe and inserted into a waste tank, is used to monitor the waste temperatures at various levels in the primary tank, usually every two feet. Temperature readings for the tank have been automatically and manually recorded since July 1989 by surveillance analysis computer systems. The maximum waste temperatures from the weekly manual readings have been plotted over time and are presented in Figure 2-4 (Rios, 1994).

It is unclear from the plotted temperature graph in Figure 2-4 whether or not the temperature of the tank contents exhibits seasonal fluctuations. Since the soil between the surface level and approximately 10 feet below surface level creates a zone that is thermally transient, diurnal and seasonal variations in temperature within the tank are expected (Freeze and Cherry, 1979). Usually the soil below this 10-foot zone attenuates the effects of changing ambient air temperature. The bottom of the tank is 60 feet below the surface level, but unlike a solid mass of soil the effects of changing air temperature are still felt because the tank is a more efficient heat conductor. The tank's metal and concrete container filled with liquid, surrounded by actively ventilated annular space and connected to the surface by risers and drywell openings, will transfer heat to and from the surface more readily. Furthermore, the active ventilation system forces heat transfer between the tank contents and the ambient air. The temperature of the waste in Tank 241-AP-106 fluctuates between a high of $77^{\circ} \mathrm{F}$ to a low of $59^{\circ} \mathrm{F}$.

Except for three periods when the thermocouple equipment was out of service, the internal temperature of Tank 241-AP-106 has been monitored approximately weekly. The three periods with no thermocouple data are from the end of the fourth quarter 1990 to the second quarter 1991, from the third quarter 1991 to the fourth quarter 1992, and from the end of the fourth quarter 1992 to the middle of the second quarter 1993.

As depicted in Figure 2-4, an increase in internal temperatures in the early part of the third quarter of 1989 appears to coincide with the addition of 709,000 gallons of dilute noncomplexed waste to the 218,000 gallons already in the tank. The temperatures reported in Figure 2-4 are from the maximum values of the thermocouples that are currently working in the tank. The temperature peaks at $77^{\circ} \mathrm{F}$ and begins a downward trend into 1990 after another transfer to the tank of 214,000 gallons of dilute non-complex waste in 1990 . 
Figure 2-4. Thermocouple Tree Raw Temperature Plot for Tank 241-AP-106 (Rios, 1994).

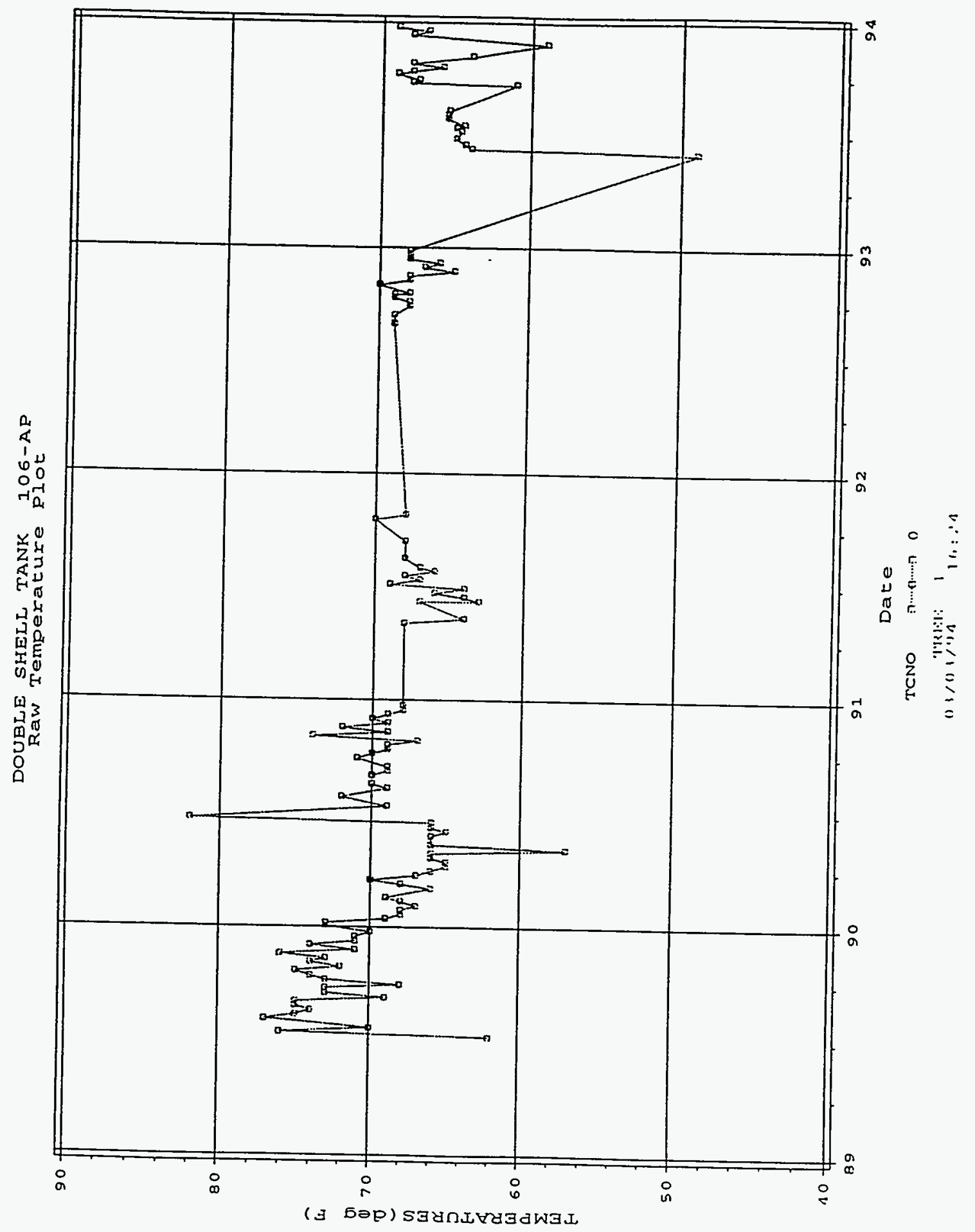


Two unusual readings were recorded in mid-1990: one unexpectedly low, the other unexpectedly high. The first, a reading of $56^{\circ} \mathrm{F}$, is a sharp departure from the stable temperatures of $66^{\circ} \mathrm{F}$ reported in the weeks immediately preceding and following the anomaly. Since no waste was added to or taken from Tank 241-AP-106 after the fourth quarter of 1989, a change in the waste's composition due to a transfer can be eliminated as a possible cause. The most likely cause appears to be an error in recording the reading (i.e, $56^{\circ} \mathrm{F}$ could have been entered for $66^{\circ} \mathrm{Fl}$, or the equipment could have malfunctioned. The second anomaly, $82^{\circ} \mathrm{F}$, was preceded and followed by readings in the upper $60 \mathrm{~s}$. Again, the cause could be either an equipment malfunction or a recording error.

Another unusual reading, $49^{\circ} \mathrm{F}$, was recorded in the second quarter of 1993 , immediately following a period for which data were not available. Considering data from previous years, temperatures at this time would be expected to be warmer; indeed, the next reading taken about a week later is $65^{\circ} \mathrm{F}$. This reading appears to be a discrepancy caused by the thermocouple equipment being brought back into service. 


\subsection{TANK SAMPLING OVERVIEW}

Sampling of Tank 241-AP-106 was accomplished to satisfy two objectives: first, to provide inorganic, radioactive, and organic information of the tank contents; second to determine whether the dilute waste can be used for blending with concentrated waste feeds. Blending may be needed to lower the radiolytic heat generation of a concentrated waste.

\subsection{DESCRIPTION OF SAMPLING EVENT}

Tank 241-AP-106 was sampled on March 16 and 17, 1993. To prove homogeneity, it was required that samples be obtained from the entire volume of the tank (Hendrickson and Welsh, 1992). Therefore, samples were taken from three equally spaced risers, situated 120 degrees apart at a radius of 20 feet from the tank's center. Two samples were drawn from each riser. Each sampling location varied randomly in depth to include the entire vertical range of the tank as shown in Figure 3-1. A duplicate sample was taken to demonstrate local homogeneity or lack thereof. Two sample bottles were drawn from five locations and four sample bottles were drawn from the sixth location. One bottle was for the inorganic analyses and one bottle was for the organic analyses. Samples were obtained by using the "bottle-ona-string" method. (The different types of sampling methods used at the Hanford site are discussed in the Tank Characterization Reference Guide [De Lorenzo et al., 1994]). Each glass sample bottle was used to collect approximately 100 milliliters of liquid. To be consistent with safety procedures that help to limit personnel exposure to hazardous ionizing radiation, no attempt was made to ensure completely full bottles; as a result, potential existed for headspace in all sample bottles.

Due to the radioactivity of the materials, refrigeration of the samples was not reasonable because of the shielding requirements during transfer. For the same reason, the existence of headspace could not be confirmed or refuted. The waste was not expected to contain any organic materials that might influence the results of the samples, so no preservatives were used in the sample bottles.

These deviations are not expected to impact the results because of the history of the waste. The majority of the waste in Tank 241-AP-106 has been stored for a number of years at temperatures at or above ambient conditions with active ventilation. The sample handling required because of the radioactivity of the waste did not cause the sample to be subjected to a more adverse environment (for volatile component removal) than was present in the tank.

\subsection{REQUESTED ANALYSES}

Seven samples (including a field blank) were transported to the Westinghouse Hanford Company 222-S Processing and Analytical Laboratory (now Hanford Analytical Services) for analysis (see Table 3-1). The seven individual samples and the composite were analyzed for inorganic and radiological constituents, and a statistical analysis was performed to verify homogeneity. The remaining seven samples and field blank were shipped to Pacific Northwest Laboratory (PNL) where they were analyzed for organic constituents (see Table 3-2). A list of the analytes evaluated in each sample by laboratory is presented in Table 3-3. 
WHC-SD-WM-ER-361 REV O

Figure 3-1. Tank 241-AP-106 Sample Locations and Tank Farm Numbers.

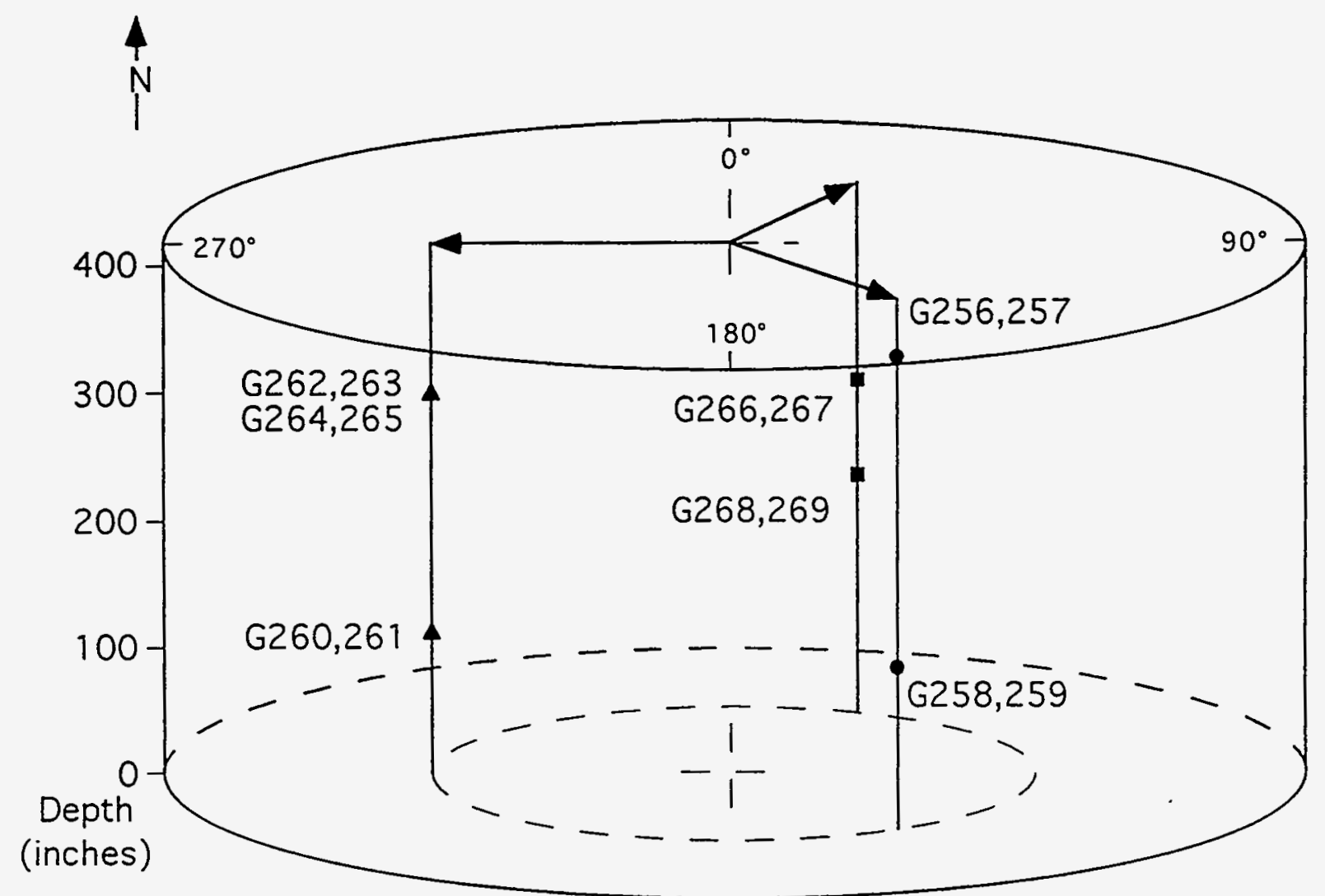

- Riser 1 (NE), 30 $\quad$ Riser 1 (SE), 150 ^ Riser 1 (W), $270^{\circ}$ 
Table 3-1. WHC Sample Numbers for Tank 241-AP-106 (Welsh, 1994).

\begin{tabular}{|c|c|c|c|c|}
\hline $\begin{array}{c}\text { Riser, } \\
\text { Angle }\end{array}$ & $\begin{array}{c}\text { Depth (from } \\
\text { tank bottom } \\
\text { in inches) }\end{array}$ & Position & $\begin{array}{c}\text { Tank Farm } \\
\text { Sample } \\
\text { Number }\end{array}$ & $\begin{array}{c}\text { Laboratory } \\
\text { Sample Number }\end{array}$ \\
\hline $1(\mathrm{NE}), 30^{\circ}$ & 264 & 1 & $\mathrm{G} 267$ & $\mathrm{G} 437$ \\
& 190 & 2 & $\mathrm{G} 269$ & $\mathrm{G} 438$ \\
\hline $1(\mathrm{SE}), 150^{\circ}$ & 375 & 5 & $\mathrm{G} 256$ & $\mathrm{G} 423$ \\
& 130 & 6 & $\mathrm{G} 258$ & $\mathrm{G} 427$ \\
\hline $1(\mathrm{~W}), 270^{\circ}$ & 301 & $3 \mathrm{~A}$ & $\mathrm{G} 262$ & $\mathrm{G} 432$ \\
& 301 & $3 \mathrm{~B}$ & $\mathrm{G} 264$ & $\mathrm{G} 433$ \\
& 112 & 4 & $\mathrm{G} 260$ & $\mathrm{G} 428$ \\
\hline- & - & - & Composite & $\mathrm{G386}{ }^{*}$ \\
\hline
\end{tabular}

"Composite sample formed from subsamples from all samples.

Table 3-2. PNL Sample Numbers (Welsh, 1994).

\begin{tabular}{|c|c|c|c|c|}
\hline $\begin{array}{c}\text { Riser, } \\
\text { Angle }\end{array}$ & $\begin{array}{c}\text { Depth Ifrom } \\
\text { tank bottom } \\
\text { in inches) }\end{array}$ & Position & $\begin{array}{c}\text { Tank Farm } \\
\text { Sample } \\
\text { Number }\end{array}$ & $\begin{array}{c}\text { PNL Laboratory } \\
\text { Sample Number }\end{array}$ \\
\hline $1(\mathrm{NE}), 30^{\circ}$ & 264 & 1 & $\mathrm{G} 266$ & $93-05398$ \\
\hline $1(\mathrm{SE}), 150^{\circ}$ & 190 & 2 & G268 & $93-05401$ \\
\hline $1(\mathrm{~W}), 270^{\circ}$ & 375 & 5 & $\mathrm{G} 257$ & $93-05395$ \\
& 130 & 6 & $\mathrm{G} 259$ & $93-05396$ \\
\hline Field Blank & 301 & $3 A$ & G263 & $93-05400$ \\
& 112 & $3 \mathrm{~B}$ & $\mathrm{G} 265$ & $93-05399$ \\
\hline
\end{tabular}


Table 3-3. Tank 241-AP-106 Samples and the Analytes Evaluated (Welsh, 1994).

\begin{tabular}{|c|c|c|c|}
\hline $\begin{array}{l}\text { Tank Farm } \\
\text { Sample } \\
\text { Numbers }\end{array}$ & $\begin{array}{c}\text { Laboratory } \\
\text { Sample } \\
\text { Numbers }\end{array}$ & Laboratory & Analytes Evaluated \\
\hline $\begin{array}{l}\text { G267 } \\
\text { G269 } \\
\text { G256 } \\
\text { G258 } \\
\text { G260 } \\
\text { G262 } \\
\text { G264 }\end{array}$ & $\begin{array}{l}\text { G437 } \\
\text { G438 } \\
\text { G423 } \\
\text { G427 } \\
\text { G428 } \\
\text { G432 } \\
\text { G433 }\end{array}$ & 222-S Laboratory & 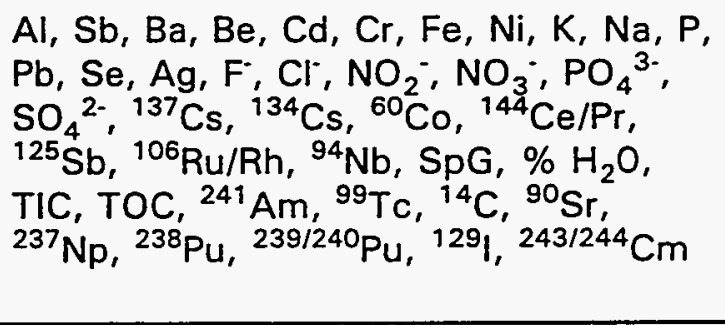 \\
\hline $\begin{array}{c}\text { Composite } \\
\text { Sample }\end{array}$ & G386 & 222-S Laboratory & 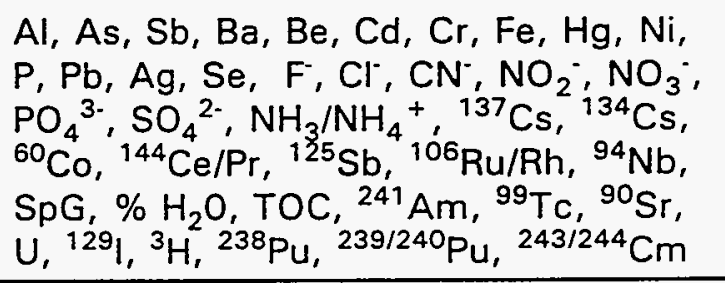 \\
\hline $\begin{array}{l}\text { G266 } \\
\text { G268 } \\
\text { G257 } \\
\text { G259 } \\
\text { G263 } \\
\text { G265 } \\
\text { G261 } \\
\text { G2 } 272\end{array}$ & $\begin{array}{l}93-05398 \\
93-05401 \\
93-05395 \\
93-05396 \\
93-05400 \\
93-05399 \\
93-05397 \\
93-05402\end{array}$ & PNL & $\begin{array}{l}\text { Volatile organics, Semivolatile organics, } \\
\text { EDTA, HEDTA, Citrate, Oxalate, } \\
\text { Glycolate }\end{array}$ \\
\hline
\end{tabular}

EDTA: ethylenediaminetetraacetic acid.

HEDTA: $\quad \mathrm{N}$-(2-hydroxyethyl)ethylenediaminetriacetic acid. 


\subsection{SAMPLE HANDLING AND ANALYTICAL SCHEME}

This chapter describes the analytical procedures performed on the samples upon receipt from the tank farm sampling activity. In addition, characterization program analyses specific to Tank 241-AP-106 are also discussed.

\subsection{WASTE DESCRIPTION}

At the time of collection, all samples were described as a clear colorless liquid with no solids or multiple phases present (Welsh, 1994). A descriptive photograph was included in Welsh (1994) that substantiated the above statement. No other information was provided regarding the description of the waste in each sample. Homogeneity of the waste is discussed in Section 7.2.

\subsection{HOLD TIME CONSIDERATIONS}

For a description of hold time considerations see the Tank Characterization Reference Guide (De Lorenzo et al., 1994).

\subsubsection{WHC - Processing and Analytical Laboratories}

Tank 241-AP-106 was sampled on March 16 and 17, 1993. Seven samples were delivered to WHC 222-S Processing and Analytical Chemistry Laboratories on March 19, 1993 for inorganic and radiochemical analyses. The sample bottles could not be confirmed to contain zero headspace due to the radioactivity of the samples (Welsh, 1994).

\subsubsection{Pacific Northwest Laboratory - Analytical Chemistry Laboratory}

Seven samples and a field blank were delivered to Pacific Northwest Laboratory (PNL) Analytical Chemistry Laboratory from March 19 to March 31, 1993 for volatile organic analyses, semivolatile organic analyses, and bulk organics. The sample bottles could not be confirmed to contain zero headspace due to the radioactivity of the samples (Welsh, 1994).

\subsection{SAMPLE PREPARATION}

A discussion concerning sample preparation in provided in the Tank Characterization Reference Guide (De Lorenzo et al., 1994).

\subsection{ANALYTICAL METHODS}

This section briefly describes the analytical methods used to characterize the waste in Tank 241-AP-106 (presented in Table 4-1), as well as those methods used to characterize the grout product fabricated from blended tank samples. The overall character of the waste is based on the analyses of the individual and composite samples. 
Table 4-1. Analytical Methods (Hendrickson and Welsh, 1992;

St. Denis, 1993)

\begin{tabular}{|c|c|c|}
\hline Analyte & Method & Procedure \\
\hline $\mathrm{Hg}$ & CVAA $^{1}$ & LA-325-104 \\
\hline As & $\mathrm{GHAA}^{2}$ & LA-355-131 \\
\hline $\mathrm{Se}$ & $\mathrm{GHAA}^{2}$ & LA-365-131 \\
\hline $238,239 / 240 \mathrm{Pu},{ }^{241} \mathrm{Am},{ }^{244} \mathrm{Cm},{ }^{237} \mathrm{~Np}$ & separation $/ \mathrm{AEA}^{3}$ & $\begin{array}{l}\text { LA- } 503-156 \\
\text { LA-933-141 }\end{array}$ \\
\hline $\begin{array}{l}\mathrm{Ag}, \mathrm{Ba}, \mathrm{Cd}, \mathrm{Cr}, \mathrm{KNa}, \mathrm{Ne}, \mathrm{Ni}, \mathrm{Pb}, \mathrm{P}, \\
\mathrm{Al}, \mathrm{Be}, \mathrm{Sb}, \mathrm{Fe}\end{array}$ & Inductively Coupled Plasma & LA-505-151 \\
\hline$U$ & Laser Fluorimetry & LA-925-106 \\
\hline $\mathrm{NH}_{3} / \mathrm{NH}_{4}^{+}$ & see $^{4}$ & LA- $634-102$ \\
\hline $\mathrm{CN}^{-}$ & Dist/Spec 5 & LA-695-102 \\
\hline $\mathrm{F}^{-}, \mathrm{Cl}^{-}, \mathrm{NO}_{2}^{-}, \mathrm{NO}_{3}^{-}, \mathrm{SO}_{4}{ }^{2-}, \mathrm{PO}_{4}{ }^{3-}$ & Ion Chromatography & LA-533-105 \\
\hline $\mathrm{OH}^{-}$ & Potentiometric Autotitration & LA-661-102 \\
\hline TOC & see $^{6}$ & LA-344-105 \\
\hline TIC & see $^{7}$ & LA-622-102 \\
\hline${ }^{90} \mathrm{Sr}$ & separation $/$ Beta $^{8}$ & LA-220-101 \\
\hline${ }^{99} \mathrm{Tc}$ & extraction/LSC ${ }^{9}$ & LA-438-101 \\
\hline${ }^{14} \mathrm{C}$ & distillation/LSC & LA-348-104 \\
\hline $\begin{array}{l}{ }^{134} \mathrm{Cs},{ }^{137} \mathrm{Cs},{ }^{94} \mathrm{Nb},{ }^{106} \mathrm{Ru} / \mathrm{Rh},{ }^{125} \mathrm{Sb}, \\
{ }^{60} \mathrm{Co},{ }^{144} \mathrm{Ce} / \mathrm{Pr}\end{array}$ & GEA & $\begin{array}{l}\text { LA- } 548-121 \\
\text { LA- } 508-052 \\
\end{array}$ \\
\hline${ }^{237} \mathrm{~Np}$ & extraction/alpha ${ }^{10}$ & LA-933-141 \\
\hline 129 & extraction/GEA ${ }^{11}$ & LA-378-103 \\
\hline${ }^{3} \mathrm{H}$ & separation/LSC & LA-218-114 \\
\hline$\% \mathrm{H}_{2} \mathrm{O}$ & Oven drying & LA-564-101 \\
\hline SpG & Density Measurement & LA-510-112 \\
\hline
\end{tabular}

${ }^{1}$ Cold Vapor Atomic Absorption Spectrophotometer

${ }^{2}$ Gaseous Hydride Atomic Absorption Spectrophotometer

${ }^{3}$ Chemical Separation (anion exchange resin) and Alpha Energy Analysis

${ }^{4}$ Distillation into a weak acid receiver and detection by back titration with a strong acid

${ }^{5}$ Acidification and Distillation followed by Spectrophotometric analysis

'Use TIC leftover carbon; TOC concentration measured by combustion and detection of $\mathrm{CO}_{2}$ by coulometry

${ }^{7}$ Acidify, purge, and heat sample; detect $\mathrm{CO}_{2}$ using coulometry

${ }^{8} \mathrm{Chemical}$ Separation along with total Beta Proportional Counting

${ }^{9}$ Extraction process followed by Liquid Scintillation Counting

${ }^{10}$ Extraction process followed by Alpha Proportional Counting

"Extraction process followed by Gamma Energy Analysis 


\subsubsection{Physical Tests}

Physical tests performed on the samples included weight percent water and specific gravity (SpG). The weight percent water was determined by oven drying a sample at $120^{\circ} \mathrm{C}$ for $18 \pm 2$ hours. Procedure LA-564-101, Rev. E-3 was used for this analysis. This is a later revision than specified in the Technical Project Plan (Procedure LA-564-101, Rev. E-1) because the procedure had to be modified to allow for calculating $w t \%$ solids rather than percent water. Therefore, this procedure applies to the determination of total dissolved solids/percent water in solutions, slurries, and solid waste. The weight percent water and the specific gravity analyses were performed on the individual samples and the composite sample in duplicate.

\subsubsection{Homogeneity of Waste}

The Sampling and Characterization Plan made an assumption that the waste contained in Tank 241-AP-106 was homogeneous. To test this assumption, an analysis of variance test was performed, using the analytical results from all seven samples. The analysis of variance test was used to determine if the variability among sample locations and the variability among sample bottles was significantly greater than zero. Test results indicating that the variability in the concentration of an analyte among locations cannot be distinguished from zero lead to the conclusion that the tank is homogeneous with respect to that analyte. The statistical method and results of the test may be found in Section 7.2 and 7.3 of this report.

\subsubsection{Chemical and Radionuclide Constituent Analysis}

All seven samples were tested for chemical and radionuclide constituents. The seven samples consisted of two samples from each riser and one duplicate. From each of the seven samples, duplicates were produced for a total of fourteen samples analyzed. Additionally, a composite sample and its duplicate (see Section 4.4.5) were analyzed for chemical and radionuclide composition.

\subsubsection{Volatile and Semivolatile Organic Constituent Analysis}

Seven samples of waste from Tank 241-AP-106 were analyzed for volatile and semivolatile constituents by PNL. The seven samples were tested using the following methods (Hendrickson and Welsh, 1992).

- Rapid screening by headspace/gas chromatography to establish laboratory dilution requirements. PNL procedure PNL-ALO-331 is a modified version of EPA Method 3810 (EPA, 1986).

- Extracting the non-polar organics into hexane or isooctane followed by gas chromatography for volatile component analysis. PNL procedure PNL-ALO-335 follows the EPA Contract Laboratory Program Statement of Work (EPA, 1991). 
- Gas chromatograph mass spectrometry (GC/MS) for semivolatile component analysis. PNL procedure PNL-ALO-345 follows the Contract Laboratory Program protocol (EPA, 1991).

- Organic complexants - glycolate and oxalate were analyzed using modified ion chromatography. Citrate, HEDTA, and EDTA were analyzed using high performance liquid chromatography (Welsh, 1994).

Quality assurance techniques of EPA methods cited were followed as closely as technically feasible. Section 5 of this report addresses the data validation findings from the analyses performed above.

\subsubsection{Grout Product Tests}

A portion of Tank 241-AP-106 waste was blended with more concentrated waste according to the test plan under the direction of grout technology personnel. Two mixtures of blended waste were prepared:

(1) $20 \%$ of Tank 241 -AP-106 waste was blended with $80 \%$ of Tank 241 -AP-105 waste,

(2) $20 \%$ of Tank 241-AP-106 waste was blended with $70 \%$ of Tank $241-\mathrm{AW}-101$ waste and $10 \%$ of tank 241-AP-102 waste.

The two blends were mixed with the formulation developed for Tank 241-AP-102 waste. The formulation consisted of $21 \%$ Type II Portland cement, $11 \%$ attapulgite clay, and $68 \%$ Class $\mathrm{F}$ fly ash. Both grout mixtures were too thick to flow. Since the grout mixtures were not suitable, the product testing was terminated (Welsh, 1994).

\subsection{MODULE SPECIFIC ANALYSES}

The characterization program for Tank 241-AP-106 was intended to satisfy criteria set by the Tank Waste Remediation System (TWRS). The TWRS sample characterization objectives are to provide adequate characterization of physical, chemical and radiological properties of Hanford Site tank wastes to support the resolution of Unreviewed Safety Questions, other safety issues surrounding the Watch List tanks, and the design of retrieval, pretreatment and final disposal systems (Bell, 1994). 


\subsection{ANALYTICAL RESULTS AND WASTE INVENTORY}

The chemical, radiochemical, physical, and organic results associated with Tank 241AP-106 are presented within this document as indicated in Table 5-1. The samples from which these results were derived were collected on March 16 and 17, 1993. This sampling event was the most recent regarding Tank 241-AP-106 and reflected the most accurate characterization of the tank waste available at the present time. A detailed discussion of the sampling process is presented in Section 3.

Table 5-1. Analytical Data Presentation Tables.

\begin{tabular}{|l|c|}
\hline \multicolumn{1}{|c|}{ Analysis } & Tabulated Results \\
\hline Tank Characterization Report Results & Table $5-2$ \\
\hline Metals & Table A-1 \\
\hline lons & Table A-2 \\
\hline Radionuclides & Table A-3 \\
\hline Organic Complexants & Table A-4 \\
\hline Physical Properties and Miscellaneous Chemical Data & Table A-5 \\
\hline Volatile and Semivolatile Organics & Table A-6 \\
\hline
\end{tabular}

In cases where a duplicate analysis was performed on a sample, the data presented in the Appendix $A$ tables were obtained by calculating an average concentration value from the initial and duplicate results. If an analyte was detected by the original but not by the duplicate sample evaluation, or vice-versa, only the single positive result was reported. When both sample runs failed to detect an analyte, the detection limit preceded by a less than $(<)$ sign was recorded as the sample result.

A representative tank concentration for each analyte was included with Appendix $A$ tables. Most of these values were obtained from a statistical model described by Welsh (1994). When insufficient data prevented the application of the statistical model, the representative tank concentration of the corresponding analyte was derived by calculating simple means from samples which yielded analyte concentrations above reported detection limits. If all available sample analyses failed to detect a particular analyte, the tank concentration of the analyte was reported to be less than the highest recorded detection limit. Detection limit values were not utilized to calculate means or corresponding standard errors.

The range of the tabulated sample data associated with each analyte was also included in the Appendix A tables. The projected tank inventory value reported in the Appendix $A$ tables was obtained by multiplying the representative tank concentration of each analyte by the volume of waste in the tank. At the time of sampling, the tank contained 4.27E + 06 liters of waste. The appropriate conversion factors were included in the calculations to obtain the reported units. 


\subsection{CHEMICAL ANALYSES}

\subsubsection{Elemental Constituents}

The following analytes were evaluated by inductively coupled plasma spectroscopy: $\mathrm{Al}, \mathrm{Sb}, \mathrm{Ba}, \mathrm{Be}, \mathrm{Cd}, \mathrm{Cr}, \mathrm{Fe}, \mathrm{Pb}, \mathrm{Ni}, \mathrm{K}, \mathrm{Ag}, \mathrm{Na}$, and $\mathrm{P}$. Arsenic and selenium were determined by gaseous hydride atomic absorption spectroscopy, and mercury was analyzed by cold vapor atomic absorption spectroscopy. The laser fluorimetry method was used to evaluate uranium. The arsenic, mercury, and uranium results were derived from the analysis of only one sample, the composite sample.

According to the laboratory results, the following were not detected in Tank 241-AP106: $\mathrm{Sb}, \mathrm{As}, \mathrm{Be}, \mathrm{Pb}, \mathrm{Hg}, \mathrm{Se}$, and $\mathrm{Ag}$. With the exception of antimony and lead, the tank concentration for each of these analytes is reported to be less than the highest detection limit obtained during the corresponding sample analyses. Since consistently higher detection limits were reported for samples $\mathrm{G} 427$ and $\mathrm{G} 428$ due to dilution factors, it may be more reasonable to assume lower limits of detection. This is especially true regarding antimony and lead; the inflated detection limit values associated with these analytes are integer multiples of the lowest reported limits. As a consequence, the lowest available detection limit values were considered to be more appropriate representations of antimony and lead in Tank 241-AP-106.

Aluminum, potassium, and sodium were the most abundant metals in Tank 241-AP106; all were present in concentrations exceeding $100 \mathrm{ppm}$. The relatively high concentration of phosphorus, $85.5 \mathrm{ppm}$, will be discussed in conjunction with the phosphate data in the next section. An estimate of the sodium concentration was derived from historical records and agreed with the analytical result to within a power of ten.

\subsection{2 lons}

The following anions were evaluated by ion chromatography: fluoride, chloride, nitrite, nitrate, sulfate, and phosphate. The data demonstrated that all of these anions are present in Tank 241-AP-106; nitrate and nitrite are the most abundant. The laboratory derived nitrate and nitrite values are further supported by the historical data since the analytical results are the same order of magnitude as the historical estimates.

If all phosphorous in Tank 241-AP-106 is assumed to be in the form of phosphate, then the inductively coupled plasma phosphorous value of $85,200 \mu \mathrm{g} / \mathrm{L}$ translates into $2.61 \mathrm{E}+05$ $\mu \mathrm{g} / \mathrm{L}$ of phosphate. The phosphate concentration in the waste was determined by ion chromatography to be $2.11 \mathrm{E}+05 \mu \mathrm{g} / \mathrm{L}$; therefore, the relative percent difference between the two phosphate values is $21 \%$. Comparable values having a relative percent difference within $\pm 20 \%$ are considered to be in good agreement. However, the discrepancy between the phosphate values may also indicate that another form of phosphorous is present in the waste.

Ammonia which was analyzed by the Kjeldahl method was not present in the tank waste above the reported detection limit. The $1430 \mu \mathrm{g} / \mathrm{mL}$ hydroxide value was determined by autotitration; this concentration translates into a $\mathrm{pH}$ of 12.9. Cyanide was evaluated spectrophotometrically after samples were initially distilled, and the analyte was present in a detectable concentration. The total inorganic carbon result agreed to within $5 \%$ of the historically derived value, and the carbonate value reported in Table 5-2 was derived from this analysis. 
Table 5-2. Tank 241-AP-106 Analytical Data. (3 pages)

\begin{tabular}{|c|c|c|c|c|}
\hline Analyte & $\begin{array}{c}\text { Historic } \\
\text { Tank } \\
\text { Content }\end{array}$ & $\begin{array}{r}\text { Tank Cha } \\
\text { Repoi }\end{array}$ & $\begin{array}{l}\text { terization } \\
\text { esult }\end{array}$ & $\begin{array}{l}\text { Total Tank } \\
\text { Inventory }\end{array}$ \\
\hline Metals & $(\mu g / L)$ & $(\mu g / L)$ & $(\mu \mathrm{g} / \mathrm{g})$ & $(\mathrm{kg})$ \\
\hline Aluminum (Al) & $\cdots$ & $2.11 E+05$ & 212 & 901 \\
\hline Antimony (Sb) & -- & $<5,250$ & $<527$ & $<22.4$ \\
\hline Arsenic (As) & -- & $<250$ & $<0.251$ & $<1.07$ \\
\hline Barium (Ba) & -- & 161 & 0.162 & 0.687 \\
\hline Beryllium (Be) & -- & $<3,830$ & $<3.85$ & $<16.4$ \\
\hline Bismuth (Bi) & - & $-\cdots$ &.- & -- \\
\hline Boron (B) & -- & $\cdots$ & $\cdots$ & $\cdots$ \\
\hline Cadmium (Cd) & -- & 5,920 & 5.94 & 25.3 \\
\hline Calcium Ca) & -- & $\cdots$ & --- & $\cdots$ \\
\hline Chromium $(\mathrm{Cr})$ & $\cdots$ & 4,740 & 4.76 & 20.2 \\
\hline Copper (Cu) & $-\cdots$ & $\cdots$ & $\cdots$ & $\cdots$ \\
\hline Iron (Fe) & $\cdots$ & 6,890 & 6.92 & 29.4 \\
\hline Lead $(\mathrm{Pb})$ & $\cdots$ & $<1,550$ & $<1.56$ & $<6.62$ \\
\hline Magnesium (Mg) & --- & -- & -- & --- \\
\hline Manganese $(\mathrm{Mn})$ & $-\cdots$ & $\cdots$ & $\cdots$ & -- \\
\hline Mercury $(\mathrm{Hg})$ & -- & $<2.50$ & $<0.00251$ & $<0.011$ \\
\hline Molybdenum (Mo) & $\cdots$ & -- & -- & -- \\
\hline Neptunium (Np) & $\cdots$ & -- & -- & $\cdots$ \\
\hline Nickel (Ni) & $\cdots$ & 408 & 0.410 & 1.74 \\
\hline Phosphorus (P) & -- & 85,200 & 85.5 & 364 \\
\hline Potassium (K) & -- & $8.18 E+05$ & 821 & 3,490 \\
\hline Selenium (Se) & -- & $<250$ & $<0.251$ & $<1.07$ \\
\hline Silicon (Si) & -- & -- & $\cdots$ & -- \\
\hline Silver $(\mathrm{Ag})$ & $\cdots$ & $<6.380$ & $<6.41$ & $<27.2$ \\
\hline Sodium $(\mathrm{Na})$ & $2.39 E+07$ & $5.53 E+06$ & 5,550 & 23,600 \\
\hline Titanium (Ti) & -- & $\cdots$ & -- & -- \\
\hline Uranium $(U)$ & -- & 3,710 & 3.72 & 15.8 \\
\hline Zinc $(Z n)$ & -- & -- & $\cdots$ & -- \\
\hline Zirconium $(\mathrm{Zr})$ & $\overline{---}$ & -- & $\cdots$ & -- \\
\hline
\end{tabular}


Table 5-2. Tank 241-AP-106 Analytical Data. (3 pages)

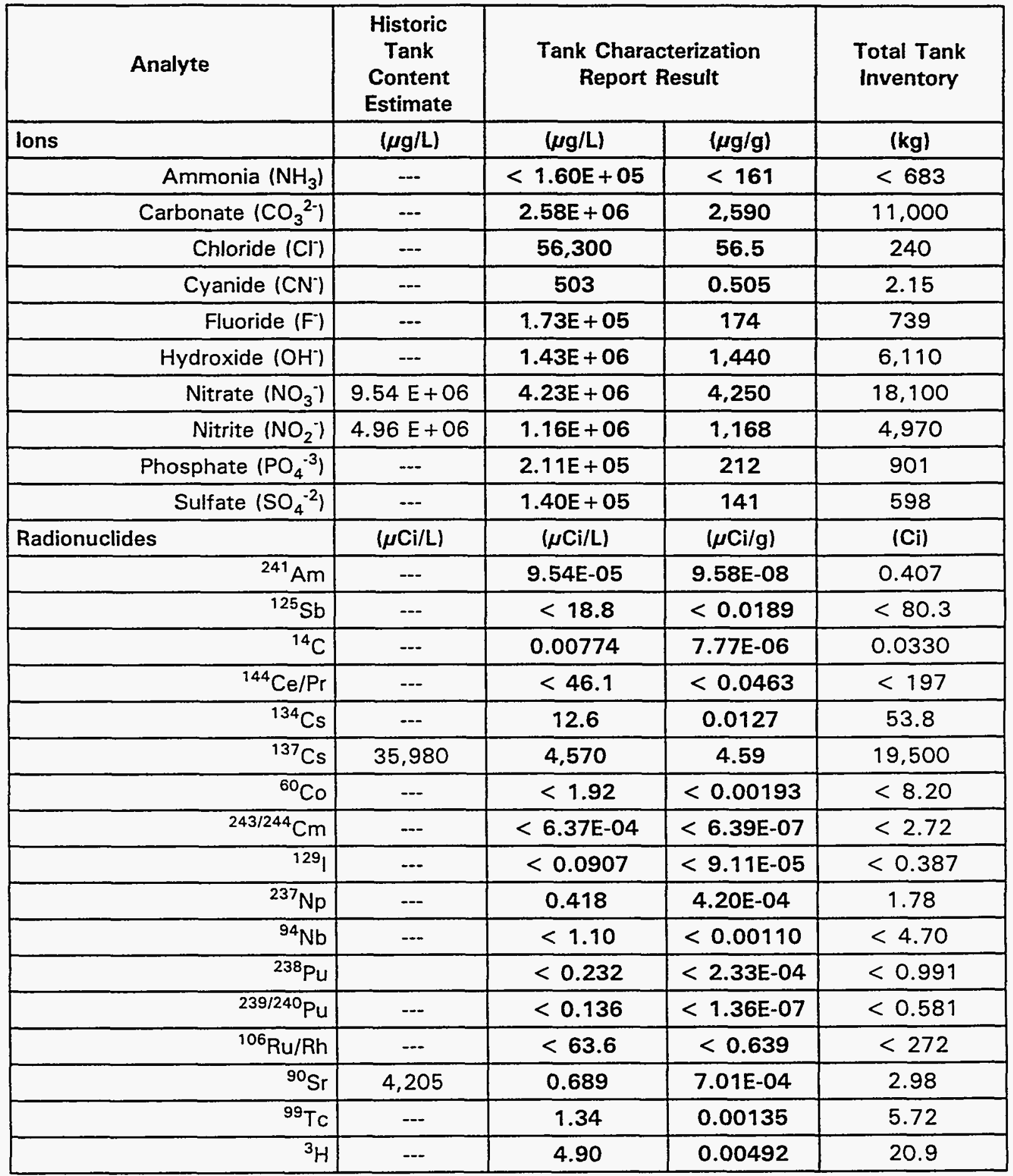


Table 5-2. Tank 241-AP-106 Analytical Data. (3 pages)

\begin{tabular}{|c|c|c|c|c|}
\hline Analyte & $\begin{array}{c}\text { Historic } \\
\text { Tank } \\
\text { Content } \\
\text { Estimate }\end{array}$ & \multicolumn{2}{|c|}{$\begin{array}{c}\text { Tank Characterization } \\
\text { Report Result }\end{array}$} & $\begin{array}{l}\text { Total Tank } \\
\text { Inventory }\end{array}$ \\
\hline Percent Water & $\ldots$ & $100.2 \%$ & $-\cdots$ & N/A \\
\hline Specific Gravity & -- & 0.996 & $\cdots$ & N/A \\
\hline $\mathrm{pH}$ & $-\cdots$ & 12.9 & --- & -- \\
\hline Viscosity & $-\cdots$ & 1 centipoise & -- & $\cdots$ \\
\hline Total Inorganic Carbon (TIC) & $\begin{array}{c}5.1 \mathrm{E}+05 \\
(\mu \mathrm{g} / \mathrm{L})\end{array}$ & $\begin{array}{c}4.86 \mathrm{E}+05 \\
(\mu \mathrm{g} / \mathrm{L})\end{array}$ & $\begin{array}{c}488 \\
(\mu \mathrm{g} / \mathrm{L})\end{array}$ & $2,080(\mathrm{~kg})$ \\
\hline Total Organic Carbon (TOC) & $-\cdots$ & $\begin{array}{c}4.97 E+05 \\
(\mu \mathrm{g} / \mathrm{L})\end{array}$ & $\begin{array}{c}499 \\
(\mu \mathrm{g} / \mathrm{L}) \\
\end{array}$ & $2,120(\mathrm{~kg})$ \\
\hline Organic Complex & $(\mu \mathrm{g} / \mathrm{L})$ & $(\mu \mathrm{g} / \mathrm{L})$ & $(\mu \mathrm{g} / \mathrm{g})$ & (kg) \\
\hline EDTA & $\cdots$ & $<20,000$ & $<20.1$ & $<85.4$ \\
\hline HEDTA & $-\cdots$ & $<20,000$ & $<20.1$ & $<85.4$ \\
\hline Citrate & $-\cdots$ & $<44,000$ & $<44.2$ & $<188$ \\
\hline Glycolate & --- & 64,300 & 64.6 & 275 \\
\hline Oxalate & $-\cdots$ & 75,700 & 76.0 & 323 \\
\hline
\end{tabular}




\subsection{RADIOLOGICAL DETERMINATIONS}

The activities of the following radionuclides were determined by GEA: ${ }^{144} \mathrm{Ce} / \mathrm{Pr},{ }^{134} \mathrm{Cs}$, ${ }^{137} \mathrm{Cs},{ }^{60} \mathrm{Co},{ }^{94} \mathrm{Nb},{ }^{106} \mathrm{Ru} / \mathrm{Rh}$, and ${ }^{125} \mathrm{Sb}$. ${ }^{3} \mathrm{H},{ }^{14} \mathrm{C}$, and ${ }^{99} \mathrm{Tc}$ were analyzed by liquid scintillation, and beta proportional counting was utilized to determine ${ }^{90} \mathrm{Sr}$ activity. Neptunium-237 was determined by alpha proportional counting, and ${ }^{129}$ / was analyzed by low energy GEA. The following were evaluated by AEA: ${ }^{239 / 240} \mathrm{Pu},{ }^{238} \mathrm{Pu},{ }^{241} \mathrm{Am}$, and ${ }^{243 / 244} \mathrm{Cm}$. Total alpha and beta analyses were not conducted.

The following radionuclides demonstrated activities above their corresponding detection limits in Tank 241-AP-106: ${ }^{241} \mathrm{Am},{ }^{14} \mathrm{C},{ }^{134} \mathrm{Cs},{ }^{137} \mathrm{Cs},{ }^{237} \mathrm{~Np},{ }^{90} \mathrm{Sr},{ }^{99} \mathrm{Tc}$, and ${ }^{3} \mathrm{H}$. The ${ }^{137} \mathrm{Cs}$ value is extremely high when compared to the activity of the remaining isotopes, but the analytical result is much less than the historical estimate even after radioactive decay is taken into account. The measured activity corresponding to ${ }^{90} \mathrm{Sr}$ is also much lower than that predicted by the historical data.

\subsection{ORGANIC CONSTITUENTS}

None of the target analytes associated with the volatile and semivolatile organic analyses were detected in the waste above 500 parts per billion. Because of their volatile nature and relatively small contribution to the waste as indicated by the historical records, the appearance of these compounds was not expected.

The total organic carbon analysis revealed the presence of $4.97 \mathrm{E}+05 \mu \mathrm{g} / \mathrm{L}$ of carbon in Tank 241-AP-106. According to the data associated with organic complexants, 64,300 $\mu \mathrm{g} / \mathrm{L}$ glycolate and $75,700 \mu \mathrm{g} / \mathrm{L}$ of oxalate were detected in Tank 241-AP-106 and accounted for approximately $8 \%$ of the organic carbon in the waste. None of the other complexants for which an analysis was conducted were present above detection limits. Since the organic carbon contribution from volatile and semi-volatile organic compounds in Tank 241-AP-106 is negligible, the remaining organic carbon in the waste is attributed to the presence of additional complexants, either intact molecules or decomposition products.

\subsection{PHYSICAL MEASUREMENTS}

\subsubsection{Percent Water and Specific Gravity}

The laboratory reported the weight percent of water and specific gravity of the waste in Tank 241-AP-106 to be $100.2 \%$ and 0.996 , respectively. The specific gravity is less than 1.00 most likely due to a low bias in the analytical method. The method requires the pipetting of very small sample volumes, approximately $200 \mu \mathrm{L}$, into preweighed vials.

\subsubsection{Rheology}

There were no viscosity measurements requested or taken on this waste; however, because the material is a dilute saline solution, the viscosity of the tank waste is estimated at 1 centipoise $(0.000672 \mathrm{lb} / \mathrm{ft}-\mathrm{s})$, the equivalent of water at $20^{\circ} \mathrm{C}\left(68^{\circ} \mathrm{F}\right)$. 


\subsubsection{Energetics}

Differential scanning calorimetry analyses were not conducted since the potential for an exothermic reaction is unlikely due to the high water content of the tank waste.

\subsection{DATA PRESENTATION}

The Tank Characterization Report Results recorded in Table 5-2 are the final constituent estimates for this document. The values are equal to the representative tank concentrations presented in the Appendix A tables. 


\subsection{ANALYTICAL RESULTS INTERPRETATION}

\subsection{TANK WASTE PROFILE}

Examination of the analytical results reveals that the waste in Tank 241-AP-106 is primarily a dilute aqueous solution of inorganic salts. The most abundant ions in the tank are sodium, potassium, aluminum, nitrite, nitrate, and hydroxide; carbonate, as indicated by the total inorganic carbon analysis, is also present at a relatively high concentration. Radionuclides which demonstrated detectable activities included ${ }^{241} \mathrm{Am},{ }^{14} \mathrm{C},{ }^{134} \mathrm{Cs},{ }^{137} \mathrm{Cs}$, ${ }^{237} \mathrm{~Np},{ }^{90} \mathrm{Sr},{ }^{99} \mathrm{Tc}$, and ${ }^{3} \mathrm{H}$. Organic constituents found in the tank include glycolate and oxalate.

\subsection{WASTE SUMMARY AND CONDITIONS}

\subsubsection{Projected Tank Heat Load}

The very low relative level of radionuclides in Tank 241-AP-106 is reflected in the low heat load (Table 6-1). Only three of the radionuclides reported in this table were detected by the analytical methods used. Detection limits for the other analytes were included in the calculation in order to obtain the most conservative estimate possible. Thus the heat load is insignificant.

\subsubsection{Regulatory Limits}

The cadmium concentration in Tank 241-AP-106 exceeded the toxicity characteristic leach procedure (TCLP) threshold value defined in the Code of Federal Regulations, 40 CFR 261 (EPA, 1990). Lead and silver concentrations were found to be less than their corresponding detection limits, but the reported limits associated with several samples were greater than the maximum allowable TCLP levels. If the waste is to be vitrified it will be necessary to determine whether or not vitrification will satisfy the TCLP requirements with respect to these metals. The calculated $\mathrm{pH}$ of 12.9 is above the Resource Conservation and Recovery Act pH limit of 12.5 for corrosivity (EPA, 1990). The $\mathrm{pH}$, however, is of little concern since the waste will be neutralized before treatment. 
Table 6-1. Tank 241-AP-106 Projected Heat Load.

\begin{tabular}{|l|c|c|}
\hline \multicolumn{1}{|c|}{ Radionuclide } & $\mathbf{C i}$ & Watts \\
\hline${ }^{241} \mathrm{Am}$ & 0.407 & $<0.0134$ \\
\hline${ }^{125} \mathrm{Sb}$ & $<80.3$ & $<0.268$ \\
\hline${ }^{144} \mathrm{Ce} / \mathrm{Pr}$ & $<197$ & $<1.58$ \\
\hline${ }^{134} \mathrm{Cs}$ & 53.8 & $<0.549$ \\
\hline${ }^{137} \mathrm{Cs}$ & 19,500 & 92.0 \\
\hline${ }^{60} \mathrm{Co}$ & $<8.20$ & $<0.126$ \\
\hline${ }^{129} \mathrm{l}$ & $<0.387$ & $<0.000181$ \\
\hline${ }^{237} \mathrm{~Np}$ & $<1.78$ & $<0.0513$ \\
\hline${ }^{238} \mathrm{Pu}$ & $<0.991$ & $<0.0323$ \\
\hline${ }^{239} / 240 \mathrm{Pu}$ & $<0.581$ & $<0.0177$ \\
\hline${ }^{106} \mathrm{Ru} / \mathrm{Rh}$ & $<272$ & $<2.62$ \\
\hline${ }^{90} \mathrm{Sr}$ & 2.98 & 0.0200 \\
\hline${ }^{99} \mathrm{Tc}$ & 5.72 & 0.00287 \\
\hline Total Watts & -- & $\sim 97.3$ \\
\hline
\end{tabular}

\subsection{PROGRAM ELEMENT SPECIFIC ANALYSES}

The sampling and analysis of Hanford Site waste tanks is driven by the need to satisfy the characterization requirements of the various Tank Waste Remediation System (TWRS) program elements. These characterization needs are implemented and documented through the Data Quality Objective (DQO) process, and expressed in a series of program specific DOO documents. The data needs are summarized in the TWRS Tank Waste Analysis Plan (Bell, 1994).

This Tank Characterization Report is the final step in the characterization of Tank 241AP-106. According to the process and issue based data requirements, the inventory estimates and waste properties contained in this report can be applied to the data requirements of the various program elements. Contained in Table 6-2 is a summary of which program data needs are fulfilled through this characterization of the waste in Tank 241-AP106, based on a review of the stated sampling and analysis requirements. In the future, the applicability of Tank Characterization Report results to each TWRS program element will be documented in tank specific Tank Characterization Plans, prior to the tank sampling. 
Table 6-2. Applicability of Characterization Information to the Data Needs of the TWRS Program Elements.

\begin{tabular}{|c|c|}
\hline Data Quality Objective & $\begin{array}{l}\text { Applicability to Characterization } \\
\text { of Tank 241-AP } 106\end{array}$ \\
\hline Tank Safety Screening & applies $^{1}$ \\
\hline Ferrocyanide Safety Issue & does not apply \\
\hline Flammable Gas Tanks Crust Burn Issue & does not apply \\
\hline Generic Tank Vapor Issue Resolution & not addressed \\
\hline Flammable Gas Tank & not completed \\
\hline Waste Compatibility & applies \\
\hline Organic Fuel Rich Tank & does not apply \\
\hline Rotary Core Vapor Sampling & does not apply \\
\hline Evaporator Operations & not completed \\
\hline Process Control & not completed \\
\hline Waste Tank Retrieval & not completed \\
\hline Waste Tank Pretreatment & not completed \\
\hline High-Level Waste Immobilization & not completed \\
\hline Low-Level Waste Immobilization & not completed \\
\hline Solid, Low-Level Waste Disposal & not completed \\
\hline RCRA Part B Permit Application & not completed \\
\hline Tank C-106 High-Heat Safety Issue & does not apply \\
\hline Organic Layer Sampling of Tank C-103 & does not apply \\
\hline Tank C-103 Vapor and Gas Sampling & does not apply \\
\hline
\end{tabular}

${ }^{1}$ The sampling requirement for the Safety Screening Data Quality Objective (Babad, 1994) calls for both vertical waste samples and a vapor space sample. The sampling and analysis of Tank 241-AP-106 supports full characterization of the waste in the tank; vapor space sampling or characterization was not conducted as part of this activity.

applies - The data needs expressed in this Data Quality Objectives document are fulfilled through this characterization report.

does not apply - The data needs expressed in this Data Quality Objectives document do not apply to the waste in Tank 241-AP-106.

not addressed - The data needs expressed in this Data Quality Objectives document were not addressed by this characterization report.

not complete - At the date of preparation of this report, this Data Quality Objectives document has not yet been completed. 


\subsection{STATISTICAL INTERPRETATION}

\subsection{MASS AND CHARGE BALANCE}

The principal objective for performing a mass and charge balance is to determine if the measurements are self-consistent. The mass and charge balance calculations also provide a method for estimating the weight percent of water. In calculating the balances, only analytes detected at a concentration of $10 \mathrm{ppm}$ or greater were considered.

Mass and charge balance results are reported in Table 7-1. Although aluminum and hydroxide ions will most likely combine in the waste to form tetrahydroxoaluminate, these ions were treated separately in Table 7-1. A calculated charge imbalance resulted due to a slight shortage of negatively charged ions. The approximate error from this discrepancy, however, was less than $1 \%$ and was not considered to adversely affect the mass balance. The mass concentration, $\mu \mathrm{g} / \mathrm{g}$, resulting from the sum of the cations and anions was subtracted from a million in order to obtain an estimated value for the weight percent of water. In other words, mass not accountable to the analyte concentrations is attributed to water. Inspection of the table demonstrates that the predicted weight percent of water in Tank $241-A P-106$ is $98.3 \%$.

\subsection{COMPOSITE SAMPLE}

For several of the analytes listed in Appendix A, only a composite sample was used to determine analyte concentration. This composite was formed using equal volumes from the six individual samples. A statistical analysis was conducted to determine if the composite results were the same as the individual sample results. A $95 \%$ confidence interval for the difference between two means indicated that they were equivalent for 17 or 18 analytes tested. This justified the use of the composite as a 7th location in the statistical analysis (Welsh, 1994).

\subsection{TANK HOMOGENEITY}

Homogeneity of Tank 241-AP-106 was determined using an analysis of variance to indicate significant differences at the 0.05 level between analyte concentrations at the six sampling locations. Except for $\mathrm{K},{ }^{137} \mathrm{Cs}$, and ${ }^{134} \mathrm{Cs}$, the analytical results indicate that the tank contents are homogeneous. The results for these three constituents at position 41112 inches from the bottom of the tank) were higher than expected, but the other two sample locations from the tank bottom (130 and 190 inches from bottom) had equivalent results. Thus the tank contents cannot be considered stratified, and are indeed homogeneous (Welsh, 1994l. 
Table 7-1. Tank 241-AP-106 Mass/Charge Balance.

\begin{tabular}{|l|c|c|}
\hline \multicolumn{1}{|c|}{ Cations } & Mass $\mu \mathrm{g} / \mathrm{g}$ & Charge $\boldsymbol{\mu m o l} / \mathrm{g}$ \\
\hline Aluminum (+3) & 212 & 23.6 \\
\hline Potassium (+1) & 821 & 21.0 \\
\hline Sodium (+1) & 5,550 & 241 \\
\hline & Anions & $\vdots$ \\
\hline Chloride (-1) & 56.5 & 1.59 \\
\hline Fluoride (-1) & 174 & 9.16 \\
\hline Hydroxide (-1) & 1,440 & 84.7 \\
\hline Nitrate (-1) & 4,250 & 68.5 \\
\hline Nitrite (-1) & 1,168 & 25.4 \\
\hline Phosphate (-3) & 212 & 6.69 \\
\hline Sulfate (-2) & 141 & 2.94 \\
\hline TIC-Carbonate (-2) & 2,590 & 86.3 \\
\hline & Totals & \\
\hline Cations & 6,580 & +286 \\
\hline Anions & 10,000 & -285 \\
\hline Water (Est.) & 983,000 & - \\
\hline
\end{tabular}

\subsection{ANALYTICAL ERROR ESTIMATION}

Analytical error consists of two parts, random and systematic. Table 7-2 outlines both the analytical and systematic error estimates, organized by analyte.

\section{Random Analytical Error}

The random analytical error can be estimated from the analytical results of the duplicate samples, or from the analysis of standards. However, the analysis of standards does not account for all the sources of variability, such as matrix interferences. Error estimates were not done for analytes with "less than" (non-detected) values.

The relative percent difference (RPD) or relative standard deviation (RSD) values for random analytical error are listed in Table 7-2. Although some of the values based on sample results appear large, none of the analytes had an RPD or RSD larger than the criterion of three times the random analytical error. For instance, values for Fe looked significant, yet all sample results were considerably less than the RPD criterion of three times $50.5 \%$, or $151.5 \%$. The values for $\mathrm{P}, \mathrm{NO}_{2}{ }^{-}, \mathrm{NO}_{3}{ }^{-}$, and TOC reflected large variations in the sample analysis results, while ${ }^{90} \mathrm{Sr}$ had a large error estimate because the analytical results were close to the detection limit. Still, all sample values were below the limits. 
Table 7-2. Measurement Error Estimates.

\begin{tabular}{|c|c|c|c|c|}
\hline \multirow{2}{*}{ 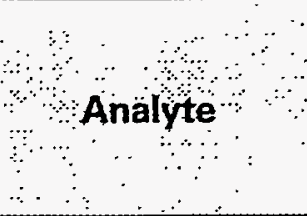 } & \multicolumn{2}{|c|}{$\begin{array}{l}\text { Rañdom analytical error } \\
\text { estimate } 1 \text { RSD }(\%)\end{array}$} & \multicolumn{2}{|c|}{$\begin{array}{c}\text { Systematic error } \\
\text { estimate } 1 \text { RSD }(\%)\end{array}$} \\
\hline & From sample & $\begin{array}{l}\text { From stanouard } \\
\text { results }\end{array}$ & $\begin{array}{c}\text { From standard } \\
\text { results }\end{array}$ & $\begin{array}{c}\text { From spike } \\
\text { analysis }\end{array}$ \\
\hline $\mathrm{Al}$ & 2.85 & 4.6 & 4.2 & NA \\
\hline $\mathrm{Cr}$ & 12.7 & 3.4 & 0.9 & 5.4 \\
\hline $\mathrm{Fe}$ & 50.5 & 2.3 & 1.8 & 27.7 \\
\hline K & 3.2 & 3.8 & 1.1 & NA \\
\hline $\mathrm{Na}$ & 0.9 & 2.2 & 1.9 & NA \\
\hline$P$ & 28.9 & 3.7 & 2.1 & 22.9 \\
\hline$F^{-}$ & 1.4 & 6.1 & 2.0 & 12.5 \\
\hline $\mathrm{Cl}^{-}$ & 17.4 & 4.6 & 1.2 & 1.7 \\
\hline $\mathrm{NO}_{2}^{-}$ & 27.9 & 3.8 & 2.0 & 6.6 \\
\hline $\mathrm{NO}_{3}{ }^{\circ}$ & 30.5 & 4.6 & 2.8 & 22.3 \\
\hline $\mathrm{PO}_{4}{ }^{3-}$ & 7.5 & 4.0 & 1.1 & 8.1 \\
\hline $\mathrm{SO}_{4}{ }^{2-}$ & 9.6 & 3.7 & 3.1 & 7.7 \\
\hline SpG & 0.2 & 0.6 & 0.9 & NA \\
\hline TIC & 19.8 & 3.5 & 1.3 & 6.1 \\
\hline TOC & 41.0 & 3.0 & 2.0 & 3.1 \\
\hline$\%$ Water & 0.3 & 1.2 & 0.7 & NA \\
\hline${ }^{137} \mathrm{Cs}$ & 1.1 & 5.1 & 1.8 & NA \\
\hline${ }^{134} \mathrm{Cs}$ & 5.2 & NA & NA & NA \\
\hline${ }^{90} \mathrm{Sr}$ & 276.3 & 8.1 & 4.5 & NA \\
\hline${ }^{14} \mathrm{C}$ & 24.5 & 3.7 & 14.4 & 12.6 \\
\hline${ }^{99} \mathrm{TC}$ & 10.6 & 8.6 & 4.3 & 13.5 \\
\hline
\end{tabular}

"Calculated from the Laboratory Measurement Control System standards analyzed in conjunction with the samples.

\section{Systematic Analytical Error}

The estimate of the systematic error is determined from the analysis of standards or spike recoveries. The control standards for matrix spike analysis are $100 \% \pm 25 \%$. As can be seen in Table 7-2, there are noticeable differences in the two estimates for some of the analytes. However, the only spike recovery not within the specified limits was Fe, and it was not included in the analysis. 


\subsection{CONCLUSIONS AND RECOMMENDATIONS}

\subsection{SAFETY ISSUES}

Characterization of Tank 241-AP-106 supports the classification of the tank as nonWatch List. Given the current tank inventory of fissionable radionuclides and organic or exothermic waste constituents, no credible potential exists for loss of tank integrity or release of radioactivity due to in-tank processes. Tank 241-AP-106 is within established operating safety requirements as defined by applicable Data Quality Objectives.

Tank 241-AP-106 is considered sound and non-leaking (Hanlon, 1994), and examination of the waste volume history supports this conclusion (Koreski, 1994). Thermocouple data indicate that there is no credible risk of self-boiling or excessive heating of the current tank contents. Given the present tank integrity and waste properties, the continued active operation of Tank 241-AP-106 for waste management and storage functions poses no unreasonable risk to personnel, the public, or the environment.

\subsection{FURTHER CHARACTERIZATION NEEDS}

Characterization of the liquid contents of Tank 241-AP-106 has been performed in this report; however, the following studies which may involve further sampling and analysis are recommended.

- An analysis of the tank vapor space would allow final resolution of any safety concerns regarding the presence of flammable or noxious fumes.

- The rheological properties of the waste may need to be evaluated before retrieval and transfer operations are conducted. However, it is expected that due to the low concentration of dissolved salts, the waste will exhibit physical properties similar to water. 


\subsection{REFERENCES}

Babad, H., 1994. Tank Safety Screening Data Quality Objective, WHC-SD-WM-004, Westinghouse Hanford Company, Richland, WA.

Bell, K.E., 1994. Tank Waste Remediation System Tank Waste Analysis Plan, WHC-SD-WMPLN-077, Rev. 0, Westinghouse Hanford Company, Richland, WA.

Conway, J.T., 1993. DNFSB Recommendation 93-5 to the Secretary of Energy, (letter 9400070 to H.R. O'Leary, DOE, July 19) Defense Nuclear Facilities Safety Board, Washington, D.C.

De Lorenzo, D.S., J.H. Rutherford, D.J. Smith, D.B. Hiller, and K.W. Johnson, 1994. Tank Characterization Reference Guide, WHC-SD-WM-TI-648, Los Alamos Technical Associates, Inc., Richland, WA.

Ecology, EPA, and DOE, 1993. Hanford Federal Facility Agreement and Consent Order, Washington State Department of Ecology, U.S. Environmental Protection Agency, and U.S. Department of Energy, Olympia, WA.

EPA, 1986. Test Methods for Evaluating Solid Waste, SW-846, 3rd Edition, U.S. Environmental Protection Agency, Washington, D.C.

EPA, 1990. "Identification and Listing of Hazardous Wastes," 40 CFR 261, U.S. Environmental Protection Agency, Washington, D.C.

EPA, 1991. Contract Laboratory Program Statement of Work, United States Environmental Protection Agency, Washington D.C.

Freeze, R.A., and J.A. Cherry, 1979. "Groundwater and Thermal Processes," Groundwater, Prentice-Hall, Inc., Englewood Cliffs, N.J.

Hanion, B.L., 1994. Tank Farm Surveillance and Waste Status Summary Report for November 1993, WHC-EP-0182-68, Westinghouse Hanford Company, Richland, WA.

Hendrickson, D.W. and T.L. Welsh, 1992. Tank 241-AP-106 Sampling and Characterization Plan, WHC-SD-WM-TP-117, Rev.0, Westinghouse Hanford Company, Richland, WA.

Husa, E.I., R.E. Raymond, R.K. Welty, S.M. Griffith, B.M. Hanlon, R.R. Rios, and N.J. Vermeulen, 1993. Hanford Site Waste Storage Tank Information Notebook, WHC-EP-0625, Westinghouse Hanford Company, Richland, WA.

Koreski, G.M., 1994. Waste Volume Projections: Thermocouple and Surface Level Readings, Westinghouse Hanford Company, Richland, WA.

Rios, R.R., 1994. Computer Automated Surveillance System, Westinghouse Hanford Company, Richland, WA. 


\section{WHC-SD-WM-ER-361 REV O}

St. Denis, R., 1993. Grout Feed Tank 106 AP, WHC-SD-WM-DP-049, Rev. 0, Westinghouse Hanford Company, Richland, WA.

Welsh, T.L., 1994. Tank 241-AP-106 Characterization Results, WHC-SD-WM-TRP-170, Rev. 0 . Westinghouse Hanford Company, Richland, WA. 
WHC-SD-WM-ER-361 REV 0

APPENDIX A

ANALYTICAL RESULTS

LATA-TCR-9404, Rev. 1 


\section{A.1 Introduction}

A.1.1 Appendix A presents the chemical and radiological characteristics of Tank 241-AP-106 in a tabular form, in terms of the specific concentrations of anions, metals, radionuclides, and physical characteristics.

The data table for each analyte lists laboratory sample identification, analytical result, range of results, an evaluated data result, and a projected tank inventory for the particular analyte. The projected tank inventory column is not applicable for the specific gravity data. The data are listed in standard notation for values $>.001$ and $<100,000$; values outside these limits are listed in scientific notation.

\section{A.2 Table Description}

\section{A.2.1 Abbreviations}

Standard abbreviations are used to describe analytical methods.

Metals:

ICP - Inductively Coupled Plasma (generic for all metals unless otherwise known)

GFAA - Graphite Furnace Atomic Absorption

GHAA - Gaseous Hydride Atomic Absorption

CVAA - Cold Vapor Atomic Absorption

FAA - Flame Atomic Absorption

Anions: IC - Ion Chromatograph

Radionuclides:

GEA - Gamma Energy Analysis

AEA - Alpha Energy Analysis

APC - Alpha Proportional Counting

BPC - Beta Proportional Counting

LSC - Liquid Scintillation Counting 
Physical Properties:

PT - Physical Testing

DM - Direct Measurement

DSC - Differential Scanning Calorimetry

TGA - Thermogravimetric Analysis

\section{A.3 Column Headings}

A.3.1 The "Analyte" column contains, in addition to the name of the analyte or physical characteristic, information about the method of measurement.

The analyte and method are presented as follows: "method.analyte". For example, the specific concentration of ${ }^{90} \mathrm{Sr}$ was measured with a beta proportional counter and is listed $\mathrm{BPC} .{ }^{90} \mathrm{Sr}$ ". The specific concentration of $\mathrm{Pb}$ was determined by the inductively coupled plasma method, and is listed as "ICP.Pb".

A.3.2 The "Laboratory Sample Identification" column lists the samples for which the analyte was measured. The "Sampling Identification Number" is different from the number assigned to the samples at the tank farm. Sampling rationale, locations, and descriptions of sampling events are contained in Section 3.0.

A.3.3 "Analytical Data Result" is the specific concentration of the analyte determined at different sampling points. No quality control data such as matrix spikes, serial dilutions, or duplicate analyses are listed. This information may be obtained from the 241-AP-106 data package (St. Denis, 1993). Unusable data (denoted by " $R$ " in the data package) will be entered with a strikeout, i.e., $395 \mathrm{ug} / \mathrm{ml}$. Unqualified data will be entered in standard form.

A.3.4 The "Range of Values" column lists the highest and the lowest values for a particular analyte. If a measurement method has a constant method detection limit (MDL), and all results are less than the MDL, no range is given. However, if the MDL changes, i.e., due to radiation background variations in radiochemistry, a range of detection limit values is given.

A.3.5 Column 5 can have various headings according to how the number was calculated. If the column is headed "Statistical Mean," the result was obtained from a statistical evaluation by Welsh (1994). "Evaluated Result" denotes a simple mean of all analytical values above the detection limit. "Largest Detection Limit" is used in cases in which all analytical results were less than the method detection limit. The largest of these values is listed and used to calculate the inventory estimate. For additional discussion, see Section 5.0.

A.3.6 Column 6 can have two headings. "Standard Error" is paired with the Column 5 heading "Statistical Mean" (see A.3.5 above), and is a product of a statistical evaluation by Welsh (1994). "Standard Deviation" is paired with "Evaluated Result," and is computed using analytical values above the detection limit. In the cases in which Column is headed "Largest Detection Limit," Column 6 is not applicable.

A.3.7 Column 7, "Projected Inventory", is the product of the concentration of the analyte and the volume of the waste in the tank. 


\section{LIST OF TABLES FOR APPENDIX A}

Table A-1. Tank 241-AP-106 Analytical Data:

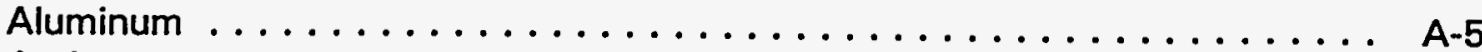

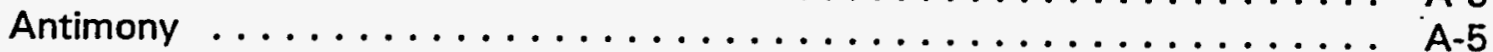

Arsenic .............................. A

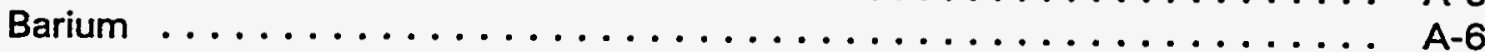

Beryllium ............................ A-7

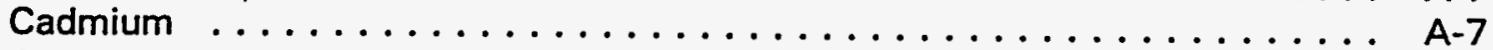

Chromium ........................... A

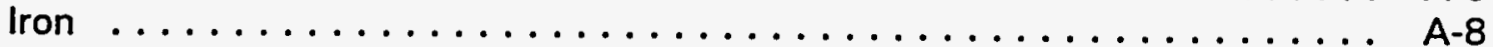

Lead ................................ A

Mercury . .......................... A-9

Nickel ............................... A $\ldots \ldots$

Phosphorus ........................... A-10

Potassium ............................A A-11

Selenium ............................ A-11

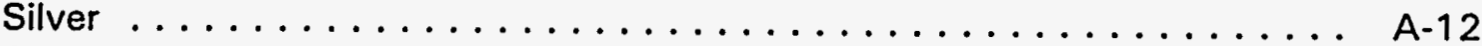

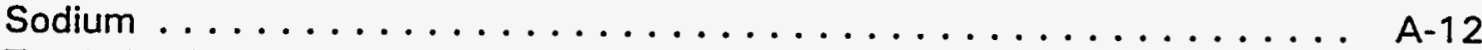

Total Uranium $\ldots \ldots \ldots \ldots \ldots \ldots \ldots \ldots \ldots \ldots \ldots \ldots \ldots$

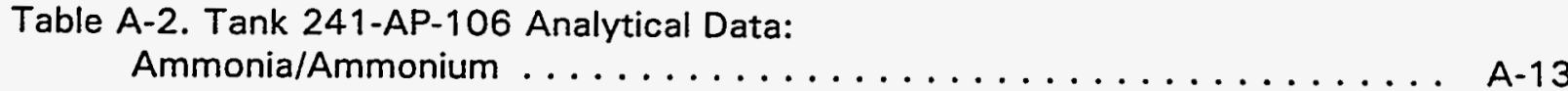

Chloride ............................. A-13

Cyanide .............................. A

Fluoride ............................ A $\ldots \ldots$ A

Hydroxide ............................. A-14

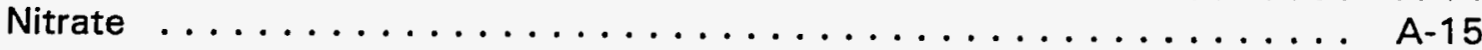

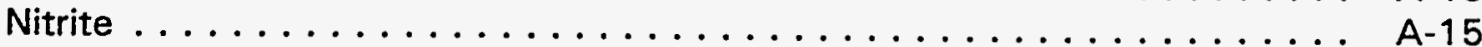

Phosphate ............................ A-16

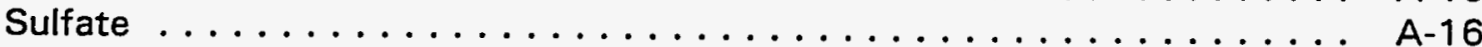

Table A-3. Tank 241-AP-106 Analytical Data:

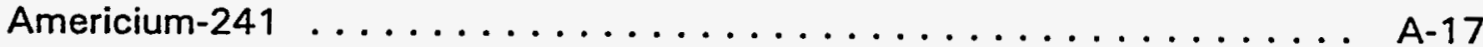

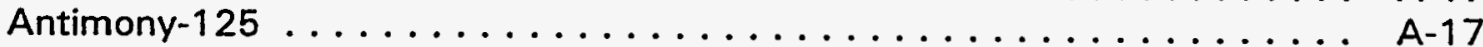

Carbon-14................................ A

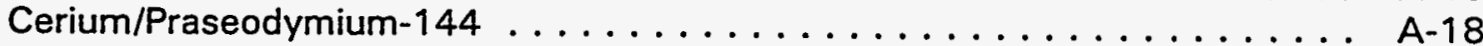

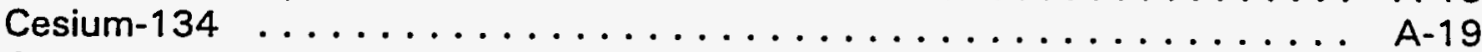

Cesium-137 ............................ A-19

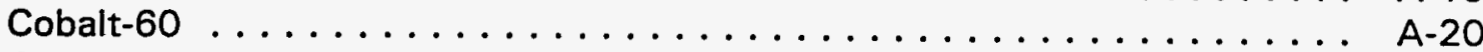

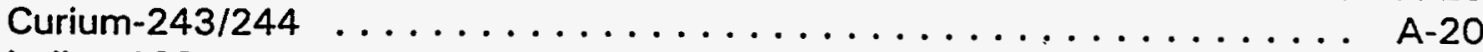

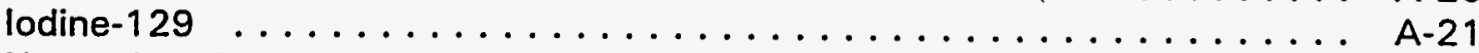

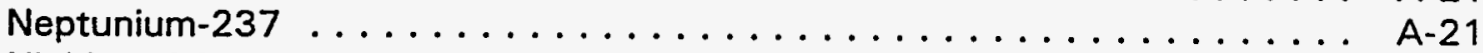

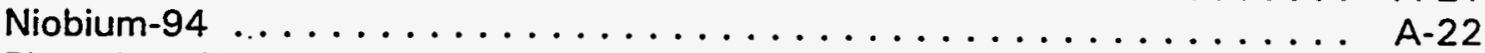

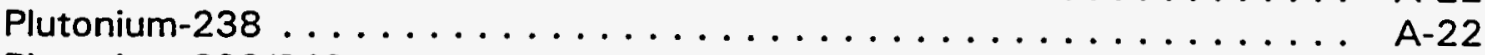

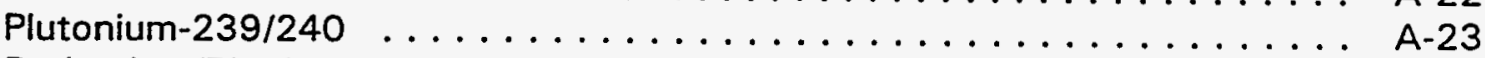

Ruthenium/Rhodium-106 ...................... A-23

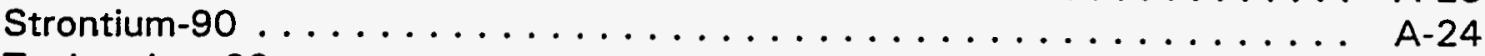

Technetium-99 ........................... A-24

Tritium ............................ A-25

LATA-TCR-9404, Rev. $1 \quad$ A-3 
LIST OF TABLES FOR APPENDIX A (continued)

Table A-4. Tank 241-AP-106 Analytical Data:

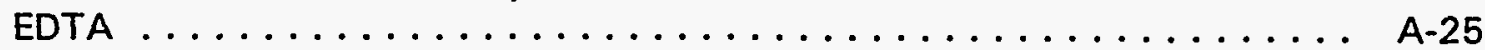

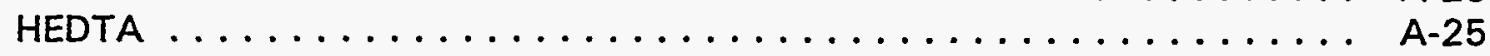

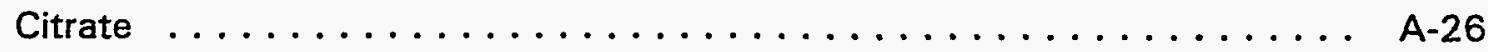

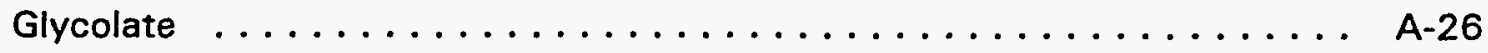

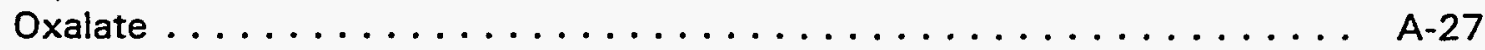

Table A-5. Tank 241-AP-106 Analytical Data:

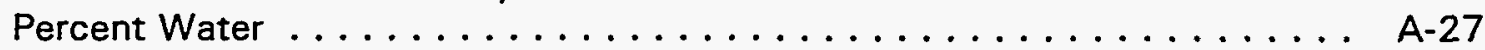

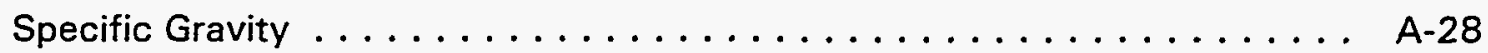

Total Inorganic Carbon $\ldots \ldots \ldots \ldots \ldots \ldots \ldots \ldots \ldots \ldots \ldots \ldots \ldots \ldots \ldots \ldots \ldots \ldots \ldots$

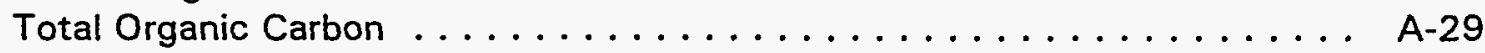

Table A-6. Tank 241-AP-106 Analytical Data:

Volatile Organic Compounds .................... A-29

Semivolatile Organic Compounds $\ldots \ldots \ldots \ldots \ldots \ldots \ldots \ldots \ldots$ A-30

LATA-TCR-9404, Rev. 1 A-4 
Table A-1. Tank 241-AP-106 Analytical Data: Aluminum

\begin{tabular}{|c|c|c|c|c|c|c|}
\hline Analyte & $\begin{array}{l}\text { Laboratory } \\
\text { Sample } \\
\text { Identification }\end{array}$ & $\begin{array}{l}\text { Arialytical } \\
\text { Data } \\
\text { Result: }\end{array}$ & $\begin{array}{l}\text { Range } \\
\text { of } \\
\text { Values }\end{array}$ & $\begin{array}{l}\text { Statistical } \\
\because \text { Mean } \\
\ddots\end{array}$ & $\begin{array}{l}\text { Standard } \\
\text { Error }\end{array}$ & $\begin{array}{l}\text { Projected } \\
\text { Inventory }\end{array}$ \\
\hline Metal & & $\mu \mathrm{g} / \mathrm{L}$ & $\mu \mathrm{g} / \mathrm{L}$ & $\mu \mathrm{g} / \mathrm{L}$ & $\mu g / L$ & kg \\
\hline \multirow[t]{8}{*}{ ICP.AI } & $\begin{array}{c}\text { Composite } \\
\text { Sample G386 }\end{array}$ & $2.28 E+05$ & \multirow{8}{*}{$\begin{array}{c}1.88 E+05 \\
\text { to } \\
2.35 E+05\end{array}$} & \multirow[t]{8}{*}{$2.11 E+05$} & \multirow[t]{8}{*}{6,186} & \multirow[t]{8}{*}{901} \\
\hline & Sample G423 & $2.02 E+05$ & & & & \\
\hline & Sample G427 & $1.88 \mathrm{E}+05$ & & & & \\
\hline & Sample G428 & $2.35 E+05$ & & & & \\
\hline & Sample G432 & $1.97 E+05$ & & & & \\
\hline & Sample G433 & $2.19 E+05$ & & & & \\
\hline & Sample G437 & $2.17 E+05$ & & & & \\
\hline & Sample G438 & $2.15 E+05$ & & & & \\
\hline
\end{tabular}

Table A-1. Tank 241-AP-106 Analytical Data: Antimony

\begin{tabular}{|c|c|c|c|c|c|c|}
\hline Analyte & $\begin{array}{c}\text { Laboratory } \\
\text { Sample } \\
\text { Identification }\end{array}$ & $\begin{array}{c}\text { Analytical } \\
\text { Data } \\
\text { Result }\end{array}$ & $\begin{array}{c}\text { Range } \\
\text { of } \\
\text { Values }\end{array}$ & $\begin{array}{l}\text { Largest } \\
\text { Detection } \\
\text { Limit }\end{array}$ & $\begin{array}{l}\text { Standard } \\
\text { Deviation }\end{array}$ & $\begin{array}{l}\text { Projected } \\
\text { Inventory }\end{array}$ \\
\hline Metal & & $\mu \mathrm{g} / \mathrm{L}$ & $\mu g / L$ & $\mu \mathrm{g} / \mathrm{L}$ & $\mu g / L$ & $\mathrm{~kg}$ \\
\hline \multirow[t]{8}{*}{ ICP.Sb } & $\begin{array}{c}\text { Composite } \\
\text { Sample G386 }\end{array}$ & $<31,500$ & \multirow{8}{*}{$\begin{array}{c}<5,250 \\
\text { to } \\
<2.68 \mathrm{E}+05\end{array}$} & \multirow[t]{8}{*}{$<5,250$} & \multirow[t]{8}{*}{ N/A } & \multirow[t]{8}{*}{$<22.4$} \\
\hline & Sample G423 & $<5,250$ & & & & \\
\hline & Sample G427 & $<2.68 E+05$ & & & & \\
\hline & Sample G428 & $<2.68 \mathrm{E}+05$ & & & & \\
\hline & Sample G432 & $<5,250$ & & & & \\
\hline & Sample G433 & $<52,500$ & & & & \\
\hline & Sample G437 & $<52,500$ & & & & \\
\hline & Sample G438 & $<52,500$ & & & & \\
\hline
\end{tabular}


Table A-1. Tank 241-AP-106 Analytical Data: Arsenic

\begin{tabular}{|c|c|c|c|c|c|c|c|}
\hline $\begin{array}{c}\text { Analyte } \\
\cdots\end{array}$ & $\begin{array}{c}\text { Laboratory } \\
\text { Sample } \\
\text { Identification }\end{array}$ & $\begin{array}{c}\text { Analytical } \\
\text { Data } \\
\text { Result }\end{array}$ & $\begin{array}{c}\text { Range } \\
\text { Ref } \\
\text { Values }\end{array}$ & $\begin{array}{c}\text { Largest } \\
\text { Detection } \\
\text { Limit }\end{array}$ & $\begin{array}{c}\text { Standard } \\
\text { Deviation }\end{array}$ & $\begin{array}{c}\text { Projected } \\
\text { Inventory }\end{array}$ \\
\hline Metal & & $\mu \mathrm{g} / \mathrm{mL}$ & $\mu \mathrm{g} / \mathrm{mL}$ & $\mu \mathrm{g} / \mathrm{mL}$ & $\mu \mathrm{g} / \mathrm{mL}$ & $\mathrm{kg}$ \\
\hline GHAA.As & $\begin{array}{c}\text { Composite } \\
\text { Sample G386 }\end{array}$ & $<0.250$ & $\mathrm{~N} / \mathrm{A}$ & $<0.250$ & $\mathrm{~N} / \mathrm{A}$ & $<1.07$ \\
\hline
\end{tabular}

Table A-1. Tank 241-AP-106 Analytical Data: Barium

\begin{tabular}{|c|c|c|c|c|c|c|}
\hline Analyte & $\begin{array}{c}\text { Laboratory } \\
\text { Sample } \\
\text { Identification }\end{array}$ & $\begin{array}{c}\text { Analytical } \\
\text { Data } \\
\text { Result }\end{array}$ & $\begin{array}{c}\text { Range } \\
\text { of } \\
\text { Values }\end{array}$ & $\begin{array}{c}\text { Evaluated } \\
\text { Data } \\
\text { Result }\end{array}$ & $\begin{array}{l}\text { Standard } \\
\text { Deviation }\end{array}$ & $\begin{array}{l}\text { Projected } \\
\text { Inventory }\end{array}$ \\
\hline Metal & & $\mu \mathrm{g} / \mathrm{L}$ & $\mu \mathrm{g} / \mathrm{L}$ & $\mu \mathrm{g} / \mathrm{L}$ & $\mu \mathrm{g} / \mathrm{L}$ & $\mathrm{kg}$ \\
\hline \multirow[t]{8}{*}{ ICP.Ba } & $\begin{array}{c}\text { Composite } \\
\text { Sample G386 }\end{array}$ & $<450$ & \multirow{8}{*}{ 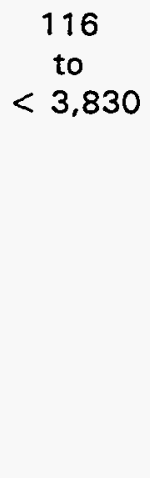 } & \multirow[t]{8}{*}{161} & \multirow[t]{8}{*}{ N/A } & \multirow[t]{8}{*}{0.687} \\
\hline & Sample G423 & 205 & & & & \\
\hline & Sample G427 & $<3,830$ & & & & \\
\hline & Sample G428 & $<3,830$ & & & & \\
\hline & Sample G432 & 116 & & & & \\
\hline & Sample G433 & $<750$ & & & & \\
\hline & Sample G437 & $<750$ & & & & \\
\hline & Sample G438 & $<750$ & & & & \\
\hline
\end{tabular}


Table A-1. Tank 241-AP-106 Analytical Data: Beryllium

\begin{tabular}{|c|c|c|c|c|c|c|}
\hline $\begin{array}{c}\text { Analyte } \\
\because\end{array}$ & $\begin{array}{c}\text { Laboratory } \\
\text { Sample } \\
\text { Identification }\end{array}$ & $\begin{array}{l}\text { Añlytical } \\
\text { Data } \\
\text { Result }\end{array}$ & $\begin{array}{l}\text { Range: } \\
\because \text { of. } \cdots \\
\text { Valiues }\end{array}$ & $\begin{array}{l}\text { Largest } \\
\text { Detection } \\
\text { Limitit }\end{array}$ & $\begin{array}{l}\text { Standard } \\
\text { Deviation }\end{array}$ & $\begin{array}{l}\text { Projected } \\
\text { Inventory }\end{array}$ \\
\hline Metal & & $\mu g / L$ & $\mu \mathrm{g} / \mathrm{L}$ & $\mu \mathrm{g} / \mathrm{L}$ & $\mu \mathrm{g} / \mathrm{L}$ & kg \\
\hline \multirow[t]{8}{*}{ ICP.Be } & $\begin{array}{c}\text { Composite } \\
\text { Sample G386 }\end{array}$ & $<450$ & \multirow{8}{*}{$\begin{aligned} & <75 \\
& \text { to } \\
< & 3,830\end{aligned}$} & \multirow[t]{8}{*}{$<3,830$} & \multirow[t]{8}{*}{ N/A } & \multirow[t]{8}{*}{$<16.4$} \\
\hline & Sample G423 & $<75$ & & & & \\
\hline & Sample G427 & $<3,830$ & & & & \\
\hline & Sample G428 & $<3,830$ & & & & \\
\hline & Sample G432 & $<75$ & & & & \\
\hline & Sample G433 & $<750$ & & & & \\
\hline & Sample G437 & $<750$ & & & & \\
\hline & Sample G438 & $<750$ & & & & \\
\hline
\end{tabular}

Table A-1. Tank 241-AP-106 Analytical Data: Cadmium

\begin{tabular}{|c|c|c|c|c|c|c|}
\hline Analyte & $\begin{array}{l}\text { Laboratory } \\
\text { Sample } \\
\text { Identification }\end{array}$ & $\begin{array}{c}\text { Analytical } \\
\text { Data } \\
\text { Result }\end{array}$ & $\begin{array}{c}\text { Range } \\
\text { of } \\
\text { Values }\end{array}$ & $\begin{array}{c}\text { Largest } \\
\text { Detection } \\
\text { Limit }\end{array}$ & $\begin{array}{l}\text { Standard } \\
\text { Deviation }\end{array}$ & $\begin{array}{l}\text { Projected } \\
\text { Inventory }\end{array}$ \\
\hline Metal & & $\mu \mathrm{g} / \mathrm{L}$ & $\mu \mathrm{g} / \mathrm{L}$ & $\mu g / L$ & $\mu \mathrm{g} / \mathrm{L}$ & $\mathrm{kg}$ \\
\hline \multirow[t]{8}{*}{ ICP.Cd } & $\begin{array}{c}\text { Composite } \\
\text { Sample G386 }\end{array}$ & 5,920 & \multirow{8}{*}{$\begin{array}{c}<150 \\
\text { to } \\
<7,650\end{array}$} & \multirow[t]{8}{*}{5,920} & \multirow[t]{8}{*}{ N/A } & \multirow[t]{8}{*}{25.3} \\
\hline & Sample G423 & $<150$ & & & & \\
\hline & Sample G427 & $<7,650$ & & & & \\
\hline & Sample G428 & $<7.650$ & & & & \\
\hline & Sample G432 & $<150$ & & & & \\
\hline & Sample G433 & $<1,500$ & & & & \\
\hline & Sample G437 & $<1,500$ & & & & \\
\hline & Sample G438 & $<1,500$ & & & & \\
\hline
\end{tabular}


Table A-1. Tank 241-AP-106 Analytical Data: Chromium

\begin{tabular}{|c|c|c|c|c|c|c|}
\hline Analyte & $\begin{array}{c}\text { 1aboratory } \\
\text { Sample: } \\
\text { Ideritification }\end{array}$ & $\begin{array}{c}\text { Analytical } \\
\text { Data } \\
\text { Result }\end{array}$ & $\begin{array}{l}\text { Range } \\
\text { - of } \\
\text { Values }\end{array}$ & $\begin{array}{c}\text { Statistical } \\
\text { Mean }\end{array}$ & $\begin{array}{c}\text { Standard } \\
\text { Error .. }\end{array}$ & $\begin{array}{l}\text { Projected } \\
\text { Inventory }\end{array}$ \\
\hline Metal & & $\mu \mathrm{g} / \mathrm{L}$ & $\mu \mathrm{g} / \mathrm{L}$ & $\mu \mathrm{g} / \mathrm{L}$ & $\mu g / L$ & $\mathrm{~kg}$ \\
\hline \multirow[t]{8}{*}{ ICP.Cr } & $\begin{array}{c}\text { Composite } \\
\text { Sample G386 }\end{array}$ & 4,260 & \multirow{8}{*}{$\begin{array}{c}3,970 \\
\text { to } \\
<11,500\end{array}$} & \multirow[t]{8}{*}{4,740} & \multirow[t]{8}{*}{244} & \multirow[t]{8}{*}{20.2} \\
\hline & Sample G423 & 4,300 & & & & \\
\hline & Sample G427 & $<11,500$ & & & & \\
\hline & Sample G428 & $<11,500$ & & & & \\
\hline & Sample G432 & 3,970 & & & & \\
\hline & Sample G433 & 4.830 & & & & \\
\hline & Sample G437 & 5,600 & & & & \\
\hline & Sample G438 & 4,680 & & & & \\
\hline
\end{tabular}

Table A-1. Tank 241-AP-106 Analytical Data: Iron

\begin{tabular}{|c|c|c|c|c|c|c|}
\hline Analyte & $\begin{array}{c}\text { Laboratory } \\
\text { Sample } \\
\text { Identification }\end{array}$ & $\begin{array}{c}\text { Analytical } \\
\text { Data } \\
\text { Result }\end{array}$ & $\begin{array}{c}\text { Range } \\
\text { of } \\
\text { Values }\end{array}$ & $\begin{array}{c}\text { Evaluated } \\
\text { Data } \\
\text { Result }\end{array}$ & $\begin{array}{l}\text { Standard } \\
\text { Deviation }\end{array}$ & $\begin{array}{l}\text { Projected } \\
\text { Inventory }\end{array}$ \\
\hline Metal & & $\mu \mathrm{g} / \mathrm{L}$ & $\mu \mathrm{g} / \mathrm{L}$ & $\mu \mathrm{g} / \mathrm{L}$ & $\mu \mathrm{g} / \mathrm{L}$ & $\mathrm{kg}$ \\
\hline \multirow[t]{8}{*}{ ICP.Fe } & $\begin{array}{c}\text { Composite } \\
\text { Sample G386 }\end{array}$ & 9,300 & \multirow{8}{*}{$\begin{array}{c}1,200 \\
\text { to } \\
<19,100\end{array}$} & \multirow[t]{8}{*}{6,890} & \multirow[t]{8}{*}{5,000} & \multirow[t]{8}{*}{29.4} \\
\hline & Sample G423 & 1,200 & & & & \\
\hline & Sample G427 & $<19,100$ & & & & \\
\hline & Sample G428 & $<19,100$ & & & & \\
\hline & Sample G432 & 1.760 & & & & \\
\hline & Sample G433 & 10,200 & & & & \\
\hline & Sample G437 & 5,160 & & & & \\
\hline & Sample G438 & 13,700 & & & & \\
\hline
\end{tabular}


Table A-1. Tank 241-AP-106 Analytical Data: Lead

\begin{tabular}{|c|c|c|c|c|c|c|}
\hline $\begin{array}{l}\text { Analyte : } \\
\ldots \ldots:\end{array}$ & $\begin{array}{l}\because \text { Laboratory } \\
\text { Sample } \\
\text { Sdentification }\end{array}$ & $\begin{array}{l}\text { Analytical } \\
\therefore \text { Data } \\
\text { Result }\end{array}$ & $\begin{array}{c}\text { Range } \\
\text { of } \\
\text { Values }\end{array}$ & $\begin{array}{l}\text { Largest } \\
\text { Detection } \\
\text { Limit }\end{array}$ & $\begin{array}{l}\text { Standard } \\
\text { Deviation }\end{array}$ & $\begin{array}{l}\text { Projected } \\
\text { Inventory }\end{array}$ \\
\hline Metal & & $\mu \mathrm{g} / \mathrm{L}$ & $\mu \mathrm{g} / \mathrm{L}$ & $\mu \mathrm{g} / \mathrm{L}$ & $\mu g / L$ & $\mathrm{~kg}$ \\
\hline \multirow[t]{8}{*}{ ICP.Pb } & $\begin{array}{c}\text { Composite } \\
\text { Sample G386 }\end{array}$ & $<9,300$ & \multirow{8}{*}{$\begin{array}{c}<1,550 \\
\text { to } \\
<79,100\end{array}$} & \multirow[t]{8}{*}{$<1,550$} & \multirow[t]{8}{*}{$N / A$} & \multirow[t]{8}{*}{$<6.62$} \\
\hline & Sample G423 & $<1.550$ & & & & \\
\hline & Sample G427 & $<79,100$ & & & & \\
\hline & Sample G428 & $<79,100$ & & & & \\
\hline & Sample G432 & $<1,550$ & & & & \\
\hline & Sample G433 & $<15,500$ & & & & \\
\hline & Sample G437 & $<15,500$ & & & & \\
\hline & Sample G438 & $<15,500$ & & & & \\
\hline
\end{tabular}

Table A-1. Tank 241-AP-106 Analytical Data: Mercury

\begin{tabular}{||c|c|c|c|c|c|c|}
\hline Analyte & $\begin{array}{c}\text { Laboratory } \\
\text { Sample } \\
\text { Identification }\end{array}$ & $\begin{array}{c}\text { Analytical } \\
\text { Data } \\
\text { Result }\end{array}$ & $\begin{array}{c}\text { Range } \\
\text { of } \\
\text { Values }\end{array}$ & $\begin{array}{c}\text { Largest } \\
\text { Detection } \\
\text { Limit }\end{array}$ & $\begin{array}{c}\text { Standard } \\
\text { Deviation }\end{array}$ & $\begin{array}{c}\text { Projected } \\
\text { Inventory }\end{array}$ \\
\hline Metal & $\mu \mathrm{g} / \mathrm{L}$ & $\mu \mathrm{g} / \mathrm{L}$ & $\mu \mathrm{g} / \mathrm{L}$ & $\mu \mathrm{g} / \mathrm{L}$ & $\mathrm{kg}$ \\
\hline CVAA.Hg & $\begin{array}{c}\text { Composite } \\
\text { Sample G386 }\end{array}$ & $<2.50$ & $\mathrm{~N} / \mathrm{A}$ & $<2.50$ & $\mathrm{~N} / \mathrm{A}$ & $<0.011$ \\
\hline
\end{tabular}


Table A-1. Tank 241-AP-106 Analytical Data: Nickel

\begin{tabular}{|c|c|c|c|c|c|c|}
\hline Analyte & $\begin{array}{c}\text { Laboratory } \\
\text { Sample } \\
\text { Identification }\end{array}$ & $\begin{array}{c}\text { Analytical } \\
\text { Data } \\
\text {. Resisitt }\end{array}$ & $\begin{array}{c}\text { Range } \\
\text { of } \\
\therefore \text { Values }\end{array}$ & $\begin{array}{c}\text { Evaluated Data } \\
\text { Resutt }\end{array}$ & $\begin{array}{l}\text { Standard } \\
\text { Deviatton }\end{array}$ & $\begin{array}{l}\text { Projected } \\
\text { Inventory }\end{array}$ \\
\hline Metal & & $\mu \mathrm{g} / \mathrm{L}$ & $\mu \mathrm{g} / \mathrm{L}$ & $\mu \mathrm{g} / \mathrm{L}$ & $\mu \mathrm{g} / \mathrm{L}$ & $\mathrm{kg}$ \\
\hline \multirow[t]{8}{*}{ ICP.Ni } & $\begin{array}{c}\text { Composite } \\
\text { Sample G386 }\end{array}$ & $<1,950$ & \multirow{8}{*}{$\begin{array}{c}<340 \\
\text { to } \\
<16,600\end{array}$} & \multirow[t]{8}{*}{408} & \multirow[t]{8}{*}{$N / A$} & \multirow[t]{8}{*}{1.74} \\
\hline & Sample G423 & 461 & & & & \\
\hline & Sample G427 & $<16,600$ & & & & \\
\hline & Sample G428 & $<16,600$ & & & & \\
\hline & Sample G432 & 354 & & & & \\
\hline & Sample G433 & $<3,250$ & & & & \\
\hline & Sample G437 & $<3,250$ & & & & \\
\hline & Sample G438 & $<3,250$ & & & & \\
\hline
\end{tabular}

Table A-1. 'Tank 241-AP-106 Analytical Data: Phosphorus

\begin{tabular}{|c|c|c|c|c|c|c|}
\hline Analyte & $\begin{array}{c}\text { Laboratory } \\
\text { Sample } \\
\text { Identification }\end{array}$ & $\begin{array}{c}\text { Analytical } \\
\text { Data } \\
\text { Result }\end{array}$ & $\begin{array}{c}\text { Range } \\
\text { of } \\
\text { Values }\end{array}$ & $\begin{array}{l}\text { Statistical } \\
\text { Mean }\end{array}$ & $\begin{array}{l}\text { Standard } \\
\text { Error }\end{array}$ & $\begin{array}{l}\text { Projected } \\
\text { Inventory }\end{array}$ \\
\hline Metal & & $\mu \mathrm{g} / \mathrm{L}$ & $\mu \mathrm{g} / \mathrm{L}$ & $\mu \mathrm{g} / \mathrm{L}$ & $\mu g / L$ & kg \\
\hline \multirow[t]{8}{*}{ ICP.P } & $\begin{array}{c}\text { Composite } \\
\text { Sample G386 }\end{array}$ & 72,300 & \multirow{8}{*}{$\begin{array}{c}61,900 \\
\text { to } \\
1.23 E+05\end{array}$} & \multirow[t]{8}{*}{85,200} & \multirow[t]{8}{*}{9,680} & \multirow[t]{8}{*}{364} \\
\hline & Sample G423 & 62,700 & & & & \\
\hline & Sample G427 & $1.14 E+05$ & & & & \\
\hline & Sample G428 & $1.23 E+05$ & & & & \\
\hline & Sample G432 & 61,900 & & & & \\
\hline & Sample G433 & 77,400 & & & & \\
\hline & Sample G437 & 68,300 & & & & \\
\hline & Sample G438 & 74,000 & & & & \\
\hline
\end{tabular}


Table A-1. Tank 241-AP-106 Analytical Data: Potassium

\begin{tabular}{|c|c|c|c|c|c|c|}
\hline Analyte & $\begin{array}{c}\text { Laboratory } \\
\text { Sample } \\
\text { Identification }\end{array}$ & $\begin{array}{c}\text { Analytical } \\
\text { Data } \\
\text { Besult }\end{array}$ & $\begin{array}{c}\text { Range } \\
\text { of } \\
\text { Yalues }\end{array}$ & $\begin{array}{c}\text { Statistical } \\
\text { Mean } \\
\end{array}$ & $\begin{array}{l}\text { Standard } \\
\text { Error }\end{array}$ & $\begin{array}{l}\text { Projected } \\
\text { inventory }\end{array}$ \\
\hline Metal & & $\mu \mathrm{g} / \mathrm{L}$ & $\mu \mathrm{g} / \mathrm{L}$ & $\mu \mathrm{g} / \mathrm{L}$ & $\mu \mathrm{g} / \mathrm{L}$ & $\mathrm{kg}$ \\
\hline \multirow[t]{8}{*}{ ICP.K } & $\begin{array}{c}\text { Composite } \\
\text { Sample G386 }\end{array}$ & $1.01 E+06$ & \multirow{8}{*}{$\begin{array}{c}6.34 E+05 \\
\text { to } \\
1.33 E+06\end{array}$} & \multirow[t]{8}{*}{$8.18 E+05$} & \multirow[t]{8}{*}{99,900} & \multirow[t]{8}{*}{3,490} \\
\hline & Sample G423 & $7.43 E+05$ & & & & \\
\hline & Sample G427 & $6.34 E+05$ & & & & \\
\hline & Sample G428 & $1.33 E+06$ & & & & \\
\hline & Sample G432 & $7.19 E+05$ & & & & \\
\hline & Sample G433 & $7.39 E+05$ & & & & \\
\hline & Sample G437 & $7.32 E+05$ & & & & \\
\hline & Sample G438 & $7.35 E+05$ & & & & \\
\hline
\end{tabular}

Table A-1. Tank 241-AP-106 Analytical Data: Selenium

\begin{tabular}{|c|c|c|c|c|c|c|}
\hline Analyte & $\begin{array}{l}\text { Laboratory } \\
\text { Sample } \\
\text { Identification }\end{array}$ & $\begin{array}{c}\text { Analytical } \\
\text { Data } \\
\text { Result }\end{array}$ & $\begin{array}{c}\text { Range } \\
\text { of } \\
\text { Values }\end{array}$ & $\begin{array}{c}\text { Largest } \\
\text { Detection } \\
\text { Limit }\end{array}$ & $\begin{array}{l}\text { Standard } \\
\text { Deviation }\end{array}$ & $\begin{array}{l}\text { Projected } \\
\text { Inventory }\end{array}$ \\
\hline Metal & & $\mu \mathrm{g} / \mathrm{mL}$ & $\mu \mathrm{g} / \mathrm{mL}$ & $\mu \mathrm{g} / \mathrm{mL}$ & $\mu \mathrm{g} / \mathrm{mL}$ & $\mathrm{kg}$ \\
\hline \multirow[t]{8}{*}{ GHAA.Se } & $\begin{array}{c}\text { Composite } \\
\text { Sample G386 }\end{array}$ & $<0.250$ & \multirow{8}{*}{$\begin{array}{c}<0.0620 \\
\text { to } \\
<0.250\end{array}$} & \multirow[t]{8}{*}{$<0.250$} & \multirow[t]{8}{*}{ N/A } & \multirow[t]{8}{*}{$<1.07$} \\
\hline & Sample G423 & $<0.0625$ & & & & \\
\hline & Sample G427 & 0.0655 & & & & \\
\hline & Sample G428 & $<0.0620$ & & & & \\
\hline & Sample G432 & $<0.0625$ & & & & \\
\hline & Sample G433 & $<0.0630$ & & & & \\
\hline & Sample G437 & $<0.0625$ & & & & \\
\hline & Sample G438 & $<0.0625$ & & & & \\
\hline
\end{tabular}


Table A-1. Tank 241-AP-106 Analytical Data: Silver

\begin{tabular}{|c|c|c|c|c|c|c|}
\hline Analyte & $\begin{array}{c}\text { Laboratory } \\
\text { Sample. } \\
\text { Identification }\end{array}$ & $\begin{array}{c}\text { Analytical } \\
\text { Data } \\
\text { Result }\end{array}$ & $\begin{array}{l}\text { Range } \\
\text { of } \\
\text { Values }\end{array}$ & $\begin{array}{l}\text { Largest } \\
\text { Detection } \\
\text { Limit }\end{array}$ & $\begin{array}{l}\text { Standard } \\
\text { Deviation }\end{array}$ & $\begin{array}{l}\text { Projected } \\
\text { Inventory }\end{array}$ \\
\hline Metal & & $\mu g / L$ & $\mu \mathrm{g} / \mathrm{L}$ & $\mu g / L$ & $\mu g / L$ & kg \\
\hline \multirow[t]{8}{*}{ ICP.Ag } & Sample G386 & $<750$ & \multirow{8}{*}{$\begin{array}{c}<125 \\
\text { to } \\
<6,380\end{array}$} & \multirow[t]{8}{*}{$<6,380$} & \multirow[t]{8}{*}{ N/A } & \multirow[t]{8}{*}{$<27.2$} \\
\hline & Sample G423 & $<125$ & & & & \\
\hline & Sample G427 & $<6,380$ & & & & \\
\hline & Sample G428 & $<6,380$ & & & & \\
\hline & Sample G432 & $<125$ & & & & \\
\hline & Sample G433 & $<1,250$ & & & & \\
\hline & Sample G437 & $<1,250$ & & & & \\
\hline & Sample G438 & $<1,250$ & & & & \\
\hline
\end{tabular}

Table A-1. Tank 241-AP-106 Analytical Data: Sodium

\begin{tabular}{|c|c|c|c|c|c|c|}
\hline Analyte & $\begin{array}{c}\text { Laboratory } \\
\text { Sample } \\
\text { Identification }\end{array}$ & $\begin{array}{c}\text { Analytical } \\
\text { Data } \\
\text { Result }\end{array}$ & $\begin{array}{c}\text { Range } \\
\text { of } \\
\text { Values }\end{array}$ & $\begin{array}{c}\text { Statistical } \\
\text { Mean }\end{array}$ & $\begin{array}{l}\text { Standard } \\
\text { Error }\end{array}$ & $\begin{array}{l}\text { Projected } \\
\text { Inventory }\end{array}$ \\
\hline Metal & & $\mu \mathrm{g} / \mathrm{L}$ & $\mu \mathrm{g} / \mathrm{L}$ & $\mu \mathrm{g} / \mathrm{L}$ & $\mu g / L$ & $\mathrm{~kg}$ \\
\hline \multirow[t]{8}{*}{ ICP.Na } & $\begin{array}{c}\text { Composite } \\
\text { Sample G386 }\end{array}$ & $6.19 E+06$ & \multirow{8}{*}{$\begin{array}{c}4.94 E+06 \\
\text { to } \\
6.81 E+06\end{array}$} & \multirow[t]{8}{*}{$5.53 E+06$} & \multirow[t]{8}{*}{$2.62 E+05$} & \multirow[t]{8}{*}{23,600} \\
\hline & Sample G423 & $5.26 E+06$ & & & & \\
\hline & Sample G427 & $4.94 E+06$ & & & & \\
\hline & Sample G428 & $6.81 E+06$ & & & & \\
\hline & Sample G432 & $5.14 E+06$ & & & & \\
\hline & Sample G433 & $5.47 E+06$ & & & & \\
\hline & Sample G437 & $5.44 E+06$ & & & & \\
\hline & Sample G438 & $5.42 E+06$ & & & & \\
\hline
\end{tabular}


Table A-1. Tank 241-AP-106 Analytical Data: Total Uranium

\begin{tabular}{|c|c|c|c|c|c|c|}
\hline \begin{tabular}{cc} 
& $\therefore$ \\
Analyte & $\vdots$ \\
\hdashline & $\cdots$
\end{tabular} & $\begin{array}{c}\text { Laboratory } \\
\text { Sample } \\
\text { Adentification }\end{array}$ & $\begin{array}{c}\text { Analytical } \\
\text { Data } \\
\text { Result }\end{array}$ & $\begin{array}{l}\text { Range } \\
\text { of } \\
\text { Values } .\end{array}$ & $\begin{array}{c}\text { Evaluated } \\
\text { Data } \\
\text { Restitt }\end{array}$ & $\begin{array}{l}\text { Standard } \\
\text { Deviation }\end{array}$ & $\begin{array}{l}\text { Projected } \\
\text { Inventory }\end{array}$ \\
\hline Metal & & $\mu \mathrm{g} / \mathrm{mL}$ & $\mu \mathrm{g} / \mathrm{mL}$ & $\mu \mathrm{g} / \mathrm{mL}$ & $\mu \mathrm{g} / \mathrm{mL}$ & kg \\
\hline LF.Total U & $\begin{array}{c}\text { Composite } \\
\text { Sample G386 }\end{array}$ & 3.71 & N/A & 3.71 & N/A & 15.8 \\
\hline
\end{tabular}

Table A-2. Tank 241-AP-106 Analytical Data: Ammonia/Ammonium

\begin{tabular}{||c|c|c|c|c|c|c|}
\hline \multicolumn{1}{|c|}{ Analyte } & $\begin{array}{c}\text { Laboratory } \\
\text { Sample } \\
\text { Identification }\end{array}$ & $\begin{array}{c}\text { Analytical } \\
\text { Data } \\
\text { Result }\end{array}$ & $\begin{array}{c}\text { Range } \\
\text { of } \\
\text { Values }\end{array}$ & $\begin{array}{c}\text { Largest } \\
\text { Detection } \\
\text { Limit }\end{array}$ & $\begin{array}{c}\text { Standard } \\
\text { Deviation }\end{array}$ & $\begin{array}{c}\text { Projected } \\
\text { Inventory }\end{array}$ \\
\hline Cation & $\mu \mathrm{g} / \mathrm{mL}$ & $\mu \mathrm{g} / \mathrm{mL}$ & $\mu \mathrm{g} / \mathrm{mL}$ & $\mu \mathrm{g} / \mathrm{mL}$ & $\mathrm{kg}$ \\
\hline $\begin{array}{c}\text { POT. } \mathrm{AUTOTIT} \\
\mathrm{NH}_{3} / \mathrm{NH}_{4}+\end{array}$ & $\begin{array}{c}\text { Composite } \\
\text { Sample G386 }\end{array}$ & $<160$ & N/A & $<160$ & $\mathrm{~N} / \mathrm{A}$ & $<683$ \\
\hline
\end{tabular}

Table A-2. Tank 241-AP-106 Analytical Data: Chloride

\begin{tabular}{|c|c|c|c|c|c|c|}
\hline Analyte & $\begin{array}{c}\text { Laboratory } \\
\text { Sample } \\
\text { Identification }\end{array}$ & $\begin{array}{c}\text { Analytical } \\
\text { Data } \\
\text { Result }\end{array}$ & $\begin{array}{c}\text { Range } \\
\text { of } \\
\text { Values }\end{array}$ & $\begin{array}{c}\text { Statistical } \\
\text { Mean }\end{array}$ & $\begin{array}{c}\text { Standard } \\
\text { Error }\end{array}$ & $\begin{array}{l}\text { Projected } \\
\text { Inventory }\end{array}$ \\
\hline Anion & & $\mu \mathrm{g} / \mathrm{mL}$ & $\mu \mathrm{g} / \mathrm{mL}$ & $\mu \mathrm{g} / \mathrm{mL}$ & $\mu \mathrm{g} / \mathrm{mL}$ & $\mathrm{kg}$ \\
\hline \multirow[t]{8}{*}{ IC. $\mathrm{Cl}^{-}$} & $\begin{array}{c}\text { Composite } \\
\text { Sample G386 }\end{array}$ & 62.8 & \multirow{8}{*}{$\begin{array}{l}46.4 \\
\text { to } \\
63.8\end{array}$} & \multirow[t]{8}{*}{56.3} & \multirow[t]{8}{*}{2.71} & \multirow[t]{8}{*}{240} \\
\hline & Sample G423 & 58.4 & & & & \\
\hline & Sample G427 & 52.7 & & & & \\
\hline & Sample G428 & 63.8 & & & & \\
\hline & Sample G432 & 57.5 & & & & \\
\hline & Sample G433 & 46.4 & & & & \\
\hline & Sample G437 & 53.3 & & & & \\
\hline & Sample G438 & 57.9 & & & & \\
\hline
\end{tabular}


Table A-2. Tank 241-AP-106 Analytical Data: Cyanide

\begin{tabular}{||c|c|c|c|c|c|c||}
\hline Analyte & $\begin{array}{c}\text { Laboratory } \\
\text { Sample } \\
\text { Identifiçation }\end{array}$ & $\begin{array}{c}\text { Analytical } \\
\text { Data } \\
\text { Result }\end{array}$ & $\begin{array}{c}\text { Range } \\
\text { of } \\
\text { Values }\end{array}$ & $\begin{array}{c}\text { Evaluated } \\
\text { Data } \\
\text { Result }\end{array}$ & $\begin{array}{c}\text { Standard } \\
\text { Deviation }\end{array}$ & $\begin{array}{c}\text { Projected } \\
\text { Inventory }\end{array}$ \\
\hline Anion & & $\mu \mathrm{g} / \mathrm{mL}$ & $\mu \mathrm{g} / \mathrm{mL}$ & $\mu \mathrm{g} / \mathrm{mL}$ & $\mu \mathrm{g} / \mathrm{mL}$ & $\mathrm{kg}$ \\
\hline $\begin{array}{c}\text { SPECTRO } \\
\text { PHOT.CN }\end{array}$ & $\begin{array}{c}\text { Composite } \\
\text { Sample G386 }\end{array}$ & 0.503 & N/A & 0.503 & N/A & 2.15 \\
\hline
\end{tabular}

Table A-2. Tank 241-AP-106 Analytical Data: Fluoride

\begin{tabular}{|c|c|c|c|c|c|c|}
\hline Analyte & $\begin{array}{c}\text { Laboratory } \\
\text { Sample } \\
\text { Identification }\end{array}$ & $\begin{array}{c}\text { Analytical } \\
\text { Data } \\
\text { Result }\end{array}$ & $\begin{array}{c}\text { Range } \\
\text { of } \\
\text { Values }\end{array}$ & $\begin{array}{c}\text { Statistical } \\
\text { Mean }\end{array}$ & $\begin{array}{l}\text { Standard } \\
\text { Error }\end{array}$ & $\begin{array}{l}\text { Projected } \\
\text { Inventory }\end{array}$ \\
\hline Anion & & $\mu \mathrm{g} / \mathrm{mL}$ & $\mu \mathrm{g} / \mathrm{mL}$ & $\mu \mathrm{g} / \mathrm{mL}$ & $\mu \mathrm{g} / \mathrm{mL}$ & $\mathrm{kg}$ \\
\hline \multirow[t]{8}{*}{ IC.F' } & $\begin{array}{c}\text { Composite } \\
\text { Sample G386 }\end{array}$ & 183 & \multirow{8}{*}{$\begin{array}{l}131 \\
\text { to } \\
325\end{array}$} & \multirow[t]{8}{*}{173} & \multirow[t]{8}{*}{28.3} & \multirow[t]{8}{*}{739} \\
\hline & Sample G423 & 325 & & & & \\
\hline & Sample G427 & 133 & & & & \\
\hline & Sample G428 & 169 & & & & \\
\hline & Sample G432 & 155 & & & & \\
\hline & Sample G433 & 137 & & & & \\
\hline & Sample G437 & 133 & & & & \\
\hline & Sample G438 & 131 & & & & \\
\hline
\end{tabular}

Table A-2. Tank 241-AP-106 Analytical Data: Hydroxide

\begin{tabular}{|r|c|c|c|c|c|c|}
\hline Analyte & $\begin{array}{c}\text { Laboratory } \\
\text { Sample } \\
\text { Identification }\end{array}$ & $\begin{array}{c}\text { Analytical } \\
\text { Data } \\
\text { Result }\end{array}$ & $\begin{array}{c}\text { Range } \\
\text { of } \\
\text { Values }\end{array}$ & $\begin{array}{c}\text { Evaluated } \\
\text { Data } \\
\text { Result }\end{array}$ & $\begin{array}{c}\text { Standard } \\
\text { Deviation }\end{array}$ & $\begin{array}{c}\text { Projected } \\
\text { Inventory }\end{array}$ \\
\hline Anion & & $\mu \mathrm{g} / \mathrm{mL}$ & $\mu \mathrm{g} / \mathrm{mL}$ & $\mu \mathrm{g} / \mathrm{mL}$ & $\mu \mathrm{g} / \mathrm{mL}$ & $\mathrm{kg}$ \\
\hline $\begin{array}{r}\text { AUTO } \\
\text { TIT.OH }\end{array}$ & $\begin{array}{c}\text { Composite } \\
\text { Sample G386 }\end{array}$ & 1,430 & $\mathrm{~N} / \mathrm{A}$ & 1,430 & $\mathrm{~N} / \mathrm{A}$ & 6,110 \\
\hline
\end{tabular}


Table A-2. Tank 241-AP-106 Analytical Data: Nitrate

\begin{tabular}{|c|c|c|c|c|c|c|}
\hline $\begin{array}{c}\quad \text { Analyte } \\
\therefore \quad \\
\because\end{array}$ & $\begin{array}{l}\text { Laboratory } \\
\text { Sample } \\
\text { Identification }\end{array}$ & $\begin{array}{l}\text { Arialytical } \\
\text { Data } \\
\text { Result }\end{array}$ & $\begin{array}{c}\text { Range } \\
\text { of } \\
\text { Vatuies }\end{array}$ & $\begin{array}{l}\text { Statistical } \\
\because \text { Error }\end{array}$ & $\begin{array}{l}\text { Standard } \\
\text { Error }\end{array}$ & $\begin{array}{l}\text { Projected } \\
\text { Inventory }\end{array}$ \\
\hline Anion & & $\mu \mathrm{g} / \mathrm{mL}$ & $\mu \mathrm{g} / \mathrm{mL}$ & $\mu \mathrm{g} / \mathrm{mL}$ & $\mu \mathrm{g} / \mathrm{mL}$ & $\mathrm{kg}$ \\
\hline \multirow[t]{8}{*}{ IC. $\mathrm{NO}_{3}^{-}$} & $\begin{array}{c}\text { Composite } \\
\text { Sample G386 }\end{array}$ & 4,370 & \multirow{8}{*}{$\begin{array}{c}3,990 \\
\text { to } \\
7,175\end{array}$} & \multirow[t]{8}{*}{4,230} & \multirow[t]{8}{*}{112} & \multirow[t]{8}{*}{18,100} \\
\hline & Sample G423 & 5,880 & & & & \\
\hline & Sample G427 & 3,990 & & & & \\
\hline & Sample G428 & 7,175 & & & & \\
\hline & Sample G432 & 4,330 & & & & \\
\hline & Sample G433 & 4,030 & & & & \\
\hline & Sample G437 & 4,130 & & & & \\
\hline & Sample G438 & 4,050 & & & & \\
\hline
\end{tabular}

Table A-2. Tank 241-AP-106 Analytical Data: Nitrite

\begin{tabular}{|c|c|c|c|c|c|c|}
\hline Analyte & $\begin{array}{c}\text { Laboratory } \\
\text { Sample } \\
\text { Identification }\end{array}$ & $\begin{array}{c}\text { Analytical } \\
\text { Data } \\
\text { Result }\end{array}$ & $\begin{array}{c}\text { Range } \\
\text { of } \\
\text { Values }\end{array}$ & $\begin{array}{c}\text { Statistical } \\
\text { Mean }\end{array}$ & $\begin{array}{l}\text { Standard } \\
\text { Error }\end{array}$ & $\begin{array}{l}\text { Projected } \\
\text { Inventory }\end{array}$ \\
\hline Anion & & $\mu \mathrm{g} / \mathrm{mL}$ & $\mu \mathrm{g} / \mathrm{mL}$ & $\mu \mathrm{g} / \mathrm{mL}$ & $\mu \mathrm{g} / \mathrm{mL}$ & kg \\
\hline \multirow[t]{8}{*}{ IC. $\mathrm{NO}_{2}^{-}$} & $\begin{array}{c}\text { Composite } \\
\text { Sample G386 }\end{array}$ & 115 & \multirow{8}{*}{$\begin{array}{c}115 \\
\text { to } \\
1.805\end{array}$} & \multirow[t]{8}{*}{1,163} & \multirow[t]{8}{*}{59.9} & \multirow[t]{8}{*}{4,970} \\
\hline & Sample G423 & 1,170 & & & & \\
\hline & Sample G427 & 1,020 & & & & \\
\hline & Sample G428 & 1,375 & & & & \\
\hline & Sample G432 & 980 & & & & \\
\hline & Sample G433 & 1,020 & & & & \\
\hline & Sample G437 & 985 & & & & \\
\hline & Sample G438 & 970 & & & & \\
\hline
\end{tabular}


Table A-2. Tank 241-AP-106 Analytical Data: Phosphate

\begin{tabular}{|c|c|c|c|c|c|c|}
\hline Analyte & $\begin{array}{l}\text { Laboratory } \\
\text { Sample } \\
\text { Identification }\end{array}$ & $\begin{array}{l}\text { Analytical } \\
\text { Data } \\
\text { Result } .\end{array}$ & $\begin{array}{c}\text { Range } \\
\text { of } \\
\text { Values }\end{array}$ & $\begin{array}{c}\text { Statistical } \\
\text { Mean }\end{array}$ & $\begin{array}{l}\text { Standard } \\
\text { Error }\end{array}$ & $\begin{array}{l}\text { Projected } \\
\text { Inventory }\end{array}$ \\
\hline Anion & & $\mu \mathrm{g} / \mathrm{mL}$ & $\mu \mathrm{g} / \mathrm{mL}$ & $\mu \mathrm{g} / \mathrm{mL}$ & $\mu \mathrm{g} / \mathrm{mL}$ & $\mathrm{kg}$ \\
\hline \multirow[t]{8}{*}{ IC. $\mathrm{PO}_{4}{ }^{3-}$} & $\begin{array}{c}\text { Composite } \\
\text { Sample G386 }\end{array}$ & 199 & \multirow{8}{*}{$\begin{array}{c}197 \\
\text { to } \\
225\end{array}$} & \multirow[t]{8}{*}{211} & \multirow[t]{8}{*}{4.40} & \multirow[t]{8}{*}{901} \\
\hline & Sample G423 & 213 & & & & \\
\hline & Sample G427 & 216 & & & & \\
\hline & Sample G428 & 215 & & & & \\
\hline & Sample G432 & 197 & & & & \\
\hline & Sample G433 & 225 & & & & \\
\hline & Sample $\mathbf{G} 437$ & 211 & & & & \\
\hline & Sample $\mathbf{G 4 3 8}$ & 204 & & & & \\
\hline
\end{tabular}

Table A-2. Tank 241-AP-106 Analytical Data: Sulfate

\begin{tabular}{|c|c|c|c|c|c|c|}
\hline Analyte & $\begin{array}{l}\text { Laboratory } \\
\text { Sample } \\
\text { Identification }\end{array}$ & $\begin{array}{c}\text { Analytical } \\
\text { Data } \\
\text { Result }\end{array}$ & $\begin{array}{c}\text { Range } \\
\text { of } \\
\text { Values }\end{array}$ & $\begin{array}{c}\text { Statistical } \\
\text { Mean }\end{array}$ & $\begin{array}{l}\text { Standard } \\
\text { Error }\end{array}$ & $\begin{array}{l}\text { Projected } \\
\text { Inventory }\end{array}$ \\
\hline Anion & & $\mu \mathrm{g} / \mathrm{mL}$ & $\mu \mathrm{g} / \mathrm{mL}$ & $\mu \mathrm{g} / \mathrm{mL}$ & $\mu \mathrm{g} / \mathrm{mL}$ & $\mathrm{kg}$ \\
\hline \multirow[t]{8}{*}{$\mathrm{IC.SO}_{4}{ }^{2-}$} & $\begin{array}{c}\text { Composite } \\
\text { Sample G386 } \\
\end{array}$ & 159 & \multirow{8}{*}{$\begin{array}{c}136 \\
\text { to } \\
159\end{array}$} & \multirow[t]{8}{*}{140} & \multirow[t]{8}{*}{2.19} & \multirow[t]{8}{*}{598} \\
\hline & Sample G423 & 136 & & & & \\
\hline & Sample G427 & 140 & & & & \\
\hline & Sample G428 & 152 & & & & \\
\hline & Sample G432 & 137 & & & & \\
\hline & ample G433 & 142 & & & & \\
\hline & Sample G437 & 137 & & & & \\
\hline & Sample G438 & 136 & & & & \\
\hline
\end{tabular}


Table A-3. Tank 241-AP-106 Analytical Data: Americium-241

\begin{tabular}{|c|c|c|c|c|c|c|}
\hline $\begin{array}{r}\text { Analyte } \\
\because \because \quad\end{array}$ & $\begin{array}{l}\text { Laboratory } \\
\text { Sample } \\
\text { Identification }\end{array}$ & $\begin{array}{l}\text { Analytical } \\
\therefore \text { Data } \\
\text { Result }\end{array}$ & $\begin{array}{c}\text { Range } \\
\text { of } \\
\text { Values }\end{array}$ & $\begin{array}{c}\text { Evaluated } \\
\text { Dáta } \\
\text { Resült }\end{array}$ & $\begin{array}{l}\text { Standard } \\
\text { Deviation }\end{array}$ & $\begin{array}{l}\text { Projected } \\
\text { Inventory }\end{array}$ \\
\hline Radionuclide & & $\mathrm{uCi} / \mathrm{mL}$ & $u \mathrm{Ci} / \mathrm{mL}$ & $\mathrm{uCi} / \mathrm{mL}$ & $\mathrm{uCi} / \mathrm{mL}$ & $\mathrm{Ci}$ \\
\hline \multirow[t]{8}{*}{ AEA. ${ }^{241} \mathrm{Am}$} & $\begin{array}{c}\text { Composite } \\
\text { Sample G386 }\end{array}$ & $<2.55 \mathrm{E}-05$ & \multirow{8}{*}{$\begin{array}{c}<2.55 \mathrm{E}-05 \\
\text { to } \\
<6.37 \mathrm{E}-04\end{array}$} & \multirow[t]{8}{*}{$9.54 \mathrm{E}-05$} & \multirow[t]{8}{*}{ N/A } & \multirow[t]{8}{*}{0.407} \\
\hline & Sample G423 & $1.00 E-04$ & & & & \\
\hline & Sample G427 & $<6.37$ E-04 & & & & \\
\hline & Sample G428 & $<6.37 E-05$ & & & & \\
\hline & Sample G432 & 9.07E-05 & & & & \\
\hline & Sample G433 & $4.20 \mathrm{E}-04$ & & & & \\
\hline & Sample G437 & $<1.37 E-04$ & & & & \\
\hline & Sample G438 & $<6.37$ E-05 & & & & \\
\hline
\end{tabular}

Table A-3. Tank 241-AP-106 Analytical Data: Antimony-125

\begin{tabular}{|c|c|c|c|c|c|c|}
\hline Analyte & $\begin{array}{c}\text { Laboratory } \\
\text { Sample } \\
\text { Identification }\end{array}$ & $\begin{array}{c}\text { Analytical } \\
\text { Data } \\
\text { Result }\end{array}$ & $\begin{array}{c}\text { Range } \\
\text { of } \\
\text { Values }\end{array}$ & $\begin{array}{c}\text { Largest } \\
\text { Detection } \\
\text { Limit }\end{array}$ & $\begin{array}{l}\text { Standard } \\
\text { Deviation }\end{array}$ & $\begin{array}{l}\text { Projected } \\
\text { Inventory }\end{array}$ \\
\hline Radionuclide & & $\mathrm{uCi} / \mathrm{mL}$ & $\mathrm{uCi} / \mathrm{mL}$ & $\mathrm{uCi} / \mathrm{mL}$ & $\mathrm{uCi} / \mathrm{mL}$ & $\mathrm{Ci}$ \\
\hline \multirow[t]{8}{*}{ GEA. ${ }^{125} \mathrm{Sb}$} & $\begin{array}{c}\text { Composite } \\
\text { Sample G386 }\end{array}$ & $<0.0153$ & \multirow{8}{*}{$\begin{array}{c}<0.00604 \\
\text { to } \\
<0.0188\end{array}$} & \multirow[t]{8}{*}{$<0.0188$} & \multirow[t]{8}{*}{ N/A } & \multirow[t]{8}{*}{$<80.3$} \\
\hline & Sample G423 & $<0.0132$ & & & & \\
\hline & Sample G427 & $<0.00604$ & & & & \\
\hline & Sample G428 & $<0.0170$ & & & & \\
\hline & Sample G432 & $<0.0188$ & & & & \\
\hline & Sample G433 & $<0.0136$ & & & & \\
\hline & Sample G437 & $<0.0106$ & & & & \\
\hline & Sample G438 & $<0.0106$ & & & & \\
\hline
\end{tabular}


Table A-3. Tank 241-AP-106 Analytical Data: Carbon-14

\begin{tabular}{|c|c|c|c|c|c|c|}
\hline Analyte & $\begin{array}{l}\text { Laboratory } \\
\text { Sample } \\
\text { Identification }\end{array}$ & $\begin{array}{c}\text { Analytical } \\
\text { Data } \\
\because \text { Result }\end{array}$ & $\begin{array}{c}\text { Range } \\
\text { of } \\
\text { Values }\end{array}$ & $\begin{array}{l}\text { Statistical } \\
\text { Mean }\end{array}$ & $\begin{array}{l}\text { Standard } \\
\text {.. Error }\end{array}$ & $\begin{array}{l}\text { Projected } \\
\text { inventory }\end{array}$ \\
\hline Radionuclide & & $\mu \mathrm{Ci} / \mathrm{mL}$ & $\mu \mathrm{Ci} / \mathrm{mL}$ & $\mu \mathrm{Ci} / \mathrm{mL}$ & $\mu \mathrm{Ci} / \mathrm{mL}$ & $\mathrm{Ci}$ \\
\hline \multirow[t]{7}{*}{ LSC. ${ }^{14} \mathrm{C}$} & Sample G423 & $1.26 \mathrm{E}-05$ & \multirow{7}{*}{$\begin{array}{c}4.93 E-06 \\
\text { to } \\
1.37 E-05\end{array}$} & \multirow[t]{7}{*}{ 7.74E-06 } & \multirow[t]{7}{*}{ 1.38E-06 } & \multirow[t]{7}{*}{0.0330} \\
\hline & Sample G427 & 6.72E-06 & & & & \\
\hline & Sample G428 & 7.30E-06 & & & & \\
\hline & Sample G432 & 1.37E-05 & & & & \\
\hline & Sample G433 & $6.21 \mathrm{E}-06$ & & & & \\
\hline & Sample G437 & $4.95 \mathrm{E}-06$ & & & & \\
\hline & Sample G438 & 4.93E-06 & & & & \\
\hline
\end{tabular}

Table A-3. Tank 241-AP-106 Analytical Data: Cerium/Praseodymium-144

\begin{tabular}{|c|c|c|c|c|c|c|}
\hline Analyte & $\begin{array}{l}\text { Laboratory } \\
\text { Sample } \\
\text { Identification }\end{array}$ & $\begin{array}{c}\text { Analytical } \\
\text { Data } \\
\text { Result }\end{array}$ & $\begin{array}{c}\text { Range } \\
\text { of } \\
\text { Values }\end{array}$ & $\begin{array}{c}\text { Largest } \\
\text { Detection } \\
\text { Limit }\end{array}$ & $\begin{array}{l}\text { Standard } \\
\text { Deviation }\end{array}$ & $\begin{array}{l}\text { Projected } \\
\text { Inventory }\end{array}$ \\
\hline Radionuclide & & $\mu \mathrm{Ci} / \mathrm{mL}$ & $\mu \mathrm{Ci} / \mathrm{mL}$ & $\mu \mathrm{Ci} / \mathrm{mL}$ & $\mu \mathrm{Ci} / \mathrm{mL}$ & $\mathrm{Ci}$ \\
\hline \multirow[t]{8}{*}{ GEA. ${ }^{144} \mathrm{Ce} / \mathrm{Pr}$} & $\begin{array}{c}\text { Composite } \\
\text { Sample G386 }\end{array}$ & $<0.0281$ & \multirow{8}{*}{$\begin{array}{c}<0.0144 \\
\text { to } \\
<0.0461\end{array}$} & \multirow[t]{8}{*}{$<0.0461$} & \multirow[t]{8}{*}{$N / A$} & \multirow[t]{8}{*}{$<197$} \\
\hline & Sample G423 & $<0.0245$ & & & & \\
\hline & Sample G427 & $<0.0144$ & & & & \\
\hline & Sample G428 & $<0.0456$ & & & & \\
\hline & Sample G432. & $<0.0472$ & & & & \\
\hline & Sample G433 & $<0.0253$ & & & & \\
\hline & Sample G437 & $<0.0194$ & & & & \\
\hline & Sample G438 & $<0.0193$ & & & & \\
\hline
\end{tabular}


Table A-3. Tank 241-AP-106 Analytical Data: Cesium-134

\begin{tabular}{|c|c|c|c|c|c|c|}
\hline $\begin{array}{r}\text { Analyte } \\
\cdots\end{array}$ & $\begin{array}{c}\text { Laboratory } \\
\text { Sample } \\
\text { Tdentification }\end{array}$ & $\begin{array}{l}\text { Analytical } \because \\
\text { Data } \\
\text { Result }\end{array}$ & $\begin{array}{c}\text { Rarige } \\
\text { of } \\
\text { Values }\end{array}$ & $\begin{array}{l}\text { Statistical } \\
\text { Mean }\end{array}$ & $\begin{array}{c}\text { Standard } \\
\text { Error }: \therefore\end{array}$ & $\begin{array}{l}\text { Projected } \\
\text { Inventory }\end{array}$ \\
\hline Radionuclide & & $\mu \mathrm{Ci} / \mathrm{mL}$ & $\mu \mathrm{Ci} / \mathrm{mL}$ & $\mu \mathrm{Ci} / \mathrm{mL}$ & $\mu \mathrm{Ci} / \mathrm{mL}$ & $\mathbf{C i}$ \\
\hline \multirow[t]{8}{*}{ GEA. ${ }^{134} \mathrm{Cs}$} & $\begin{array}{c}\text { Composite } \\
\text { Sample G386 }\end{array}$ & 0.0174 & \multirow{8}{*}{$\begin{array}{c}0.0124 \\
\text { to } \\
0.0242\end{array}$} & \multirow[t]{8}{*}{0.0126} & \multirow[t]{8}{*}{ 7.3OE-04 } & \multirow[t]{8}{*}{53.8} \\
\hline & Sample G423 & 0.0126 & & & & \\
\hline & Sample G427 & 0.0124 & & & & \\
\hline & ample G428 & 0.0242 & & & & \\
\hline & Sample G432 & 0.0130 & & & & \\
\hline & Sample G433 & 0.0132 & & & & \\
\hline & Sample G437 & 0.0124 & & & & \\
\hline & Sample G438 & 0.0126 & & & & \\
\hline
\end{tabular}

Table A-3. Tank 241-AP-106 Analytical Data: Cesium-137

\begin{tabular}{|c|c|c|c|c|c|c|}
\hline Analyte & $\begin{array}{c}\text { Laboratory } \\
\text { Sample } \\
\text { Identification }\end{array}$ & $\begin{array}{c}\text { Analytical } \\
\text { Data } \\
\text { Result }\end{array}$ & $\begin{array}{c}\text { Range } \\
\text { of } \\
\text { Values }\end{array}$ & $\begin{array}{c}\text { Statistical } \\
\text { Mean }\end{array}$ & $\begin{array}{l}\text { Standard } \\
\text { Error }\end{array}$ & $\begin{array}{l}\text { Projected } \\
\text { Inventory }\end{array}$ \\
\hline Radionuclide & & $\mu \mathrm{Ci} / \mathrm{mL}$ & $\mu \mathrm{Ci} / \mathrm{mL}$ & $\mu \mathrm{Ci} / \mathrm{mL}$ & $\mu \mathrm{Ci} / \mathrm{mL}$ & $\mathrm{Ci}$ \\
\hline \multirow[t]{8}{*}{ GEA. ${ }^{137} \mathrm{Cs}$} & $\begin{array}{c}\text { Composite } \\
\text { Sample G386 }\end{array}$ & 5.99 & \multirow{8}{*}{$\begin{array}{c}4.29 \\
\text { to } \\
9.30\end{array}$} & \multirow[t]{8}{*}{4.57} & \multirow[t]{8}{*}{0.222} & \multirow[t]{8}{*}{19,500} \\
\hline & Sample G423 & 4.29 & & & & \\
\hline & Sample G427 & 4.74 & & & & \\
\hline & Sample G428 & 9.30 & & & & \\
\hline & Sample G432 & 4.36 & & & & \\
\hline & Sample G433 & 4.64 & & & & \\
\hline & Sample G437 & 4.70 & & & & \\
\hline & Sample G438 & 4.64 & & & & \\
\hline
\end{tabular}


WHC-SD-WM-ER-361 REV 0

Table A-3. Tank 241-AP-106 Analytical Data: Cobalt-60

\begin{tabular}{|c|c|c|c|c|c|c|}
\hline $\begin{array}{r}\text { Analyte } \\
\ldots \\
\end{array}$ & $\begin{array}{c}\text { Laboratory } \\
\text { Sample } \\
\text { Identification }\end{array}$ & $\begin{array}{c}\text { Analytical } \\
\text { Data } \\
\text { Result : }\end{array}$ & $\begin{array}{c}\text { Range } \\
\text { of } \\
\text { Values }\end{array}$ & $\begin{array}{c}\text { Largest } \\
\text { Detection } \\
\therefore \quad \text { Limit }\end{array}$ & $\begin{array}{r}\text { Standard } \\
\text { Deviation }\end{array}$ & $\begin{array}{l}\text { Projected } \\
\text { Inventory }\end{array}$ \\
\hline Radionuclide & & $\mu \mathrm{Ci} / \mathrm{mL}$ & $\mu \mathrm{Ci} / \mathrm{mL}$ & $\mu \mathrm{Ci} / \mathrm{mL}$ & $\mu \mathrm{Ci} / \mathrm{mL}$ & $\mathrm{Ci}$ \\
\hline \multirow[t]{8}{*}{ GEA ${ }^{60} \mathrm{Co}$} & $\begin{array}{c}\text { Composite } \\
\text { Sample } 6386\end{array}$ & $<0.00114$ & \multirow{8}{*}{$\begin{array}{c}<2.19 E-04 \\
\text { to } \\
<0.00192\end{array}$} & \multirow[t]{8}{*}{$<0.00192$} & \multirow[t]{8}{*}{ N/A } & \multirow[t]{8}{*}{$<8.20$} \\
\hline & Sample G423 & $<0.00133$ & & & & \\
\hline & Sample G427 & $<2.19 \mathrm{E}-04$ & & & & \\
\hline & Sample G428 & $<6.30$ E-04 & & & & \\
\hline & Sample G432 & $<0.00192$ & & & & \\
\hline & Sample G433 & $<0.00125$ & & & & \\
\hline & Sample G437 & $<4.55 \mathrm{E}-04$ & & & & \\
\hline & Sample G438 & $<$ 5.57E-04 & & & & \\
\hline
\end{tabular}

Table A-3. Tank 241-AP-106 Analytical Data: Curium-243/244

\begin{tabular}{|c|c|c|c|c|c|c|}
\hline Analyte & $\begin{array}{c}\text { Laboratory } \\
\text { Sample } \\
\text { Identification }\end{array}$ & $\begin{array}{c}\text { Analytical } \\
\text { Data } \\
\text { Result }\end{array}$ & $\begin{array}{c}\text { Range } \\
\text { of } \\
\text { Values }\end{array}$ & $\begin{array}{c}\text { Largest } \\
\text { Detection } \\
\text { Limit }\end{array}$ & $\begin{array}{l}\text { Standard } \\
\text { Deviation }\end{array}$ & $\begin{array}{l}\text { Projected } \\
\text { Inventory }\end{array}$ \\
\hline Radionuclide & & $\mu \mathrm{Ci} / \mathrm{mL}$ & $\mu \mathrm{Ci} / \mathrm{mL}$ & $\mu \mathrm{Ci} / \mathrm{mL}$ & $\mu \mathrm{Ci} / \mathrm{mL}$ & $\mathrm{Ci}$ \\
\hline \multirow[t]{8}{*}{ AEA. ${ }^{243 / 244} \mathrm{Cm}$} & $\begin{array}{c}\text { Composite } \\
\text { Sample G386 }\end{array}$ & $<2.55 \mathrm{E}-04$ & \multirow{8}{*}{$\begin{array}{c}<1.74 \mathrm{E}-04 \\
\text { to } \\
<6.37 \mathrm{E}-04\end{array}$} & \multirow[t]{8}{*}{$<6.37$ E-04 } & \multirow[t]{8}{*}{ N/A } & \multirow[t]{8}{*}{$<2.72$} \\
\hline & Sample G423 & $<1.74 \mathrm{E}-04$ & & & & \\
\hline & Sample G427 & $<6.37$ E-04 & & & & \\
\hline & Sample G428 & $<6.16 \mathrm{E}-04$ & & & & \\
\hline & Sample G432 & $<6.37 \mathrm{E}-04$ & & & & \\
\hline & Sample G433 & $<4.25 \mathrm{E}-04$ & & & & \\
\hline & Sample G437 & $<3.75 \mathrm{E}-04$ & & & & \\
\hline & Sample G438 & $<5.94 \mathrm{E}-04$ & & & & \\
\hline
\end{tabular}


Table A-3. Tank 241-AP-106 Analytical Data: lodine-129

\begin{tabular}{|c|c|c|c|c|c|c|}
\hline$\because \quad$ Analyte & $\begin{array}{l}\text { Laboratory } \\
\text { Sample } \\
\text { Adentification }\end{array}$ & $\begin{array}{c}\text { Analytical } \\
\text { OData } \\
\text { Result }\end{array}$ & $\begin{array}{c}\text { Range } \\
\text { Wof } \\
\text { Values }\end{array}$ & $\begin{array}{c}\text { Largest: } \\
\text { Detection } \\
\ddots \text { Limithit }\end{array}$ & $\begin{array}{l}\text { Standard } \\
\text { Deviation }\end{array}$ & $\begin{array}{l}\text { Projected } \\
\text { Inventory }\end{array}$ \\
\hline Radionuclide & & $\mu \mathrm{Ci} / \mathrm{mL}$ & $\mu \mathrm{Ci} / \mathrm{mL}$ & $\mu \mathrm{Ci} / \mathrm{mL}$ & $\mu \mathrm{Ci} / \mathrm{mL}$ & $\mathrm{Ci}$ \\
\hline \multirow[t]{8}{*}{ GEA. ${ }^{129}$} & $\begin{array}{c}\text { Composite } \\
\text { Sample G386 }\end{array}$ & $<3.59 \mathrm{E}-05$ & \multirow{8}{*}{$\begin{array}{c}<3.33 \mathrm{E}-05 \\
\text { to } \\
<9.07 \mathrm{E}-05\end{array}$} & \multirow[t]{8}{*}{$<9.07 \mathrm{E}-05$} & \multirow[t]{8}{*}{$N / A$} & \multirow[t]{8}{*}{$<0.387$} \\
\hline & Sample G423 & $<4.26 \mathrm{E}-05$ & & & & \\
\hline & Sample G427 & $<3.37$ E-05 & & & & \\
\hline & Sample G428 & $<4.29 \mathrm{E}-05$ & & & & \\
\hline & Sample G432 & $<9.07 \mathrm{E}-05$ & & & & \\
\hline & Sample G433 & $<3.72 \mathrm{E}-05$ & & & & \\
\hline & Sample G437 & $<3.33 \mathrm{E}-05$ & & & & \\
\hline & Sample G438 & $<3.74 \mathrm{E}-05$ & & & & \\
\hline
\end{tabular}

Table A-3. Tank 241-AP-106 Analytical Data: Neptunium-237

\begin{tabular}{|c|c|c|c|c|c|c|}
\hline Analyte & $\begin{array}{l}\text { Laboratory } \\
\text { Sample } \\
\text { Identification }\end{array}$ & $\begin{array}{c}\text { Analytical } \\
\text { Data } \\
\text { Result }\end{array}$ & $\begin{array}{c}\text { Range } \\
\text { of } \\
\text { Values }\end{array}$ & $\begin{array}{c}\text { Largest } \\
\text { Detection } \\
\text { Limit }\end{array}$ & $\begin{array}{l}\text { Standard } \\
\text { Deviation }\end{array}$ & $\begin{array}{l}\text { Projected } \\
\text { Inventory }\end{array}$ \\
\hline Radionuclide & & $\mu \mathrm{Ci} / \mathrm{mL}$ & $\mu \mathrm{Ci} / \mathrm{mL}$ & $\mu \mathrm{Ci} / \mathrm{mL}$ & $\mu \mathrm{Ci} / \mathrm{mL}$ & $\mathrm{Ci}$ \\
\hline \multirow[t]{7}{*}{ APC. ${ }^{237} \mathrm{~Np}$} & Sample G423 & $<4.32 \mathrm{E}-04$ & \multirow{7}{*}{$\begin{array}{c}<3.89 \mathrm{E}-04 \\
\text { to } \\
4.18 \mathrm{E}-04\end{array}$} & \multirow[t]{7}{*}{$4.18 \mathrm{E}-04$} & \multirow[t]{7}{*}{ N/A } & \multirow[t]{7}{*}{1.78} \\
\hline & Sample G427 & $<3.89 \mathrm{E}-04$ & & & & \\
\hline & Sample G428 & $4.18 E-04$ & & & & \\
\hline & Sample G432 & $<3.89 E-04$ & & & & \\
\hline & Sample G433 & $<3.89 \mathrm{E}-04$ & & & & \\
\hline & Sample G437 & $<3.89 \mathrm{E}-04$ & & & & \\
\hline & Sample G438 & $<3.89 \mathrm{E}-04$ & & & & \\
\hline
\end{tabular}


Table A-3. Tank 241-AP-106 Analytical Data: Niobium-94

\begin{tabular}{|c|c|c|c|c|c|c|}
\hline $\begin{array}{r}\text { Analyte } \\
. \\
\end{array}$ & $\begin{array}{c}\text { Laboratory } \\
\text { Sample } \\
\text { Identifiçation }\end{array}$ & $\begin{array}{c}\text { Analytical : } \\
\text { Data } \\
\therefore \text { Result }\end{array}$ & $\begin{array}{ll} & \text { Range } \\
\therefore \quad \text { of } \\
\therefore \quad \text { Values }\end{array}$ & $\begin{array}{l}\text { Largest } \\
\text { Detection } \\
\therefore \text {. Limit. }\end{array}$ & $\begin{array}{l}\text { Standard } \\
\text { Deviation }\end{array}$ & $\begin{array}{l}\text { Projected } \\
\text { Inventory }\end{array}$ \\
\hline Radionuclide & & $\mu \mathrm{Ci} / \mathrm{mL}$ & $\mu \mathrm{Ci} / \mathrm{mL}$ & $\mu \mathrm{Ci} / \mathrm{mL}$ & $\mu \mathrm{Ci} / \mathrm{mL}$ & $\mathrm{Ci}$ \\
\hline \multirow[t]{8}{*}{ GEA. ${ }^{94} \mathrm{Nb}$} & $\begin{array}{c}\text { Composite } \\
\text { Sample G386 }\end{array}$ & $<0.00110$ & \multirow{8}{*}{$\begin{array}{c}<6.46 E-04 \\
\text { to } \\
<0.00110\end{array}$} & \multirow[t]{8}{*}{$<0.00110$} & \multirow[t]{8}{*}{ N/A } & \multirow[t]{8}{*}{$<4.70$} \\
\hline & Sample G423 & $<1.16 \mathrm{E}-03$ & & & & \\
\hline & Sample G427 & $<4.21 \mathrm{E}-04$ & & & & \\
\hline & Sample G428 & $<9.63 \mathrm{E}-04$ & & & & \\
\hline & Sample G432 & $<1.39 \mathrm{E}-03$ & & & & \\
\hline & Sample G433 & $<1.15 \mathrm{E}-03$ & & & & \\
\hline & Sample G437 & $<6.86 \mathrm{E}-04$ & & & & \\
\hline & Sample G438 & $<6.48 \mathrm{E}-04$ & & & & \\
\hline
\end{tabular}

Table A-3. Tank 241-AP-106 Analytical Data: Plutonium-238

\begin{tabular}{|c|c|c|c|c|c|c|}
\hline Analyte & $\begin{array}{c}\text { Laboratory } \\
\text { Sample } \\
\text { Identification }\end{array}$ & $\begin{array}{c}\text { Analytical } \\
\text { Data } \\
\text { Result }\end{array}$ & $\begin{array}{c}\text { Range } \\
\text { of } \\
\text { Values }\end{array}$ & $\begin{array}{c}\text { Largest } \\
\text { Detection } \\
\text { Limit }\end{array}$ & $\begin{array}{l}\text { Standard } \\
\text { Deviation }\end{array}$ & $\begin{array}{l}\text { Projected } \\
\text { Inventory }\end{array}$ \\
\hline Radionuclide & & $\mu \mathrm{Ci} / \mathrm{mL}$ & $\mu \mathrm{Ci} / \mathrm{mL}$ & $\mu \mathrm{Ci} / \mathrm{mL}$ & $\mu \mathrm{Ci} / \mathrm{mL}$ & $\mathrm{Ci}$ \\
\hline \multirow[t]{8}{*}{ AEA. ${ }^{238} \mathrm{Pu}$} & $\begin{array}{c}\text { Composite } \\
\text { Sample G386 }\end{array}$ & $<2.07$ E-05 & \multirow{8}{*}{$\begin{array}{c}<2.07 \mathrm{E}-05 \\
\text { to } \\
<2.32 \mathrm{E}-04\end{array}$} & \multirow[t]{8}{*}{$<2.32 \mathrm{E}-04$} & \multirow[t]{8}{*}{ N/A } & \multirow[t]{8}{*}{$<0.991$} \\
\hline & Sample G423 & $<2.32 \mathrm{E}-04$ & & & & \\
\hline & Sample G427 & $<2.01 E-04$ & & & & \\
\hline & Sample G428 & $<2.07 E-04$ & & & & \\
\hline & Sample G432 & $<1.05 \mathrm{E}-04$ & & & & \\
\hline & ample G433 & $<2.06 E-04$ & & & & \\
\hline & Sample G437 & $<1.99 E-04$ & & & & \\
\hline & Sample G438 & $<1.93 E-04$ & & & & \\
\hline
\end{tabular}


Table A-3. Tank 241-AP-106 Analytical Data: Plutonium-239/240

\begin{tabular}{|c|c|c|c|c|c|c|}
\hline \begin{tabular}{l} 
Analyte \\
\hdashline$\quad: \quad:$
\end{tabular} & $\begin{array}{l}\text { Laboratory } \\
\text { Tdentification } \\
\text { Sample }\end{array}$ & $\begin{array}{c}\text { Añalytical } \\
\text { Data } \\
\text { Result }\end{array}$ & $\begin{array}{l}\text { Range } \\
\text { of } \\
\text { yalues }\end{array}$ & $\begin{array}{l}\text { Largest } \\
\text { Detection } \\
\text { Limit }\end{array}$ & $\begin{array}{l}\text { Standard } \\
\text { Deviation }\end{array}$ & $\begin{array}{l}\text { Projected } \\
\text { Inventory }\end{array}$ \\
\hline Radionuclide & & $\mu \mathrm{Ci} / \mathrm{mL}$ & $\mu \mathrm{Ci} / \mathrm{mL}$ & $\mu \mathrm{Ci} / \mathrm{mL}$ & $\mu \mathrm{Ci} / \mathrm{mL}$ & $\mathrm{Ci}$ \\
\hline \multirow[t]{8}{*}{ AEA. ${ }^{239 / 240} \mathrm{Pu}$} & $\begin{array}{c}\text { Composite } \\
\text { Sample G386 }\end{array}$ & $<1.32 \mathrm{E}-05$ & \multirow{8}{*}{$\begin{array}{c}<1.32 \mathrm{E}-05 \\
\text { to } \\
<1.36 \mathrm{E}-04\end{array}$} & \multirow[t]{8}{*}{$<1.36 \mathrm{E}-04$} & \multirow[t]{8}{*}{ N/A } & \multirow[t]{8}{*}{$<0.581$} \\
\hline & Sample G423 & $<1.32 \mathrm{E}-04$ & & & & \\
\hline & Sample G427 & $<1.31 E-04$ & & & & \\
\hline & Sample G428 & $<1.33 E-04$ & & & & \\
\hline & Sample G432 & $<1.06 \mathrm{E}-04$ & & & & \\
\hline & Sample G433 & $<1.35 \mathrm{E}-04$ & & & & \\
\hline & Sample G437 & $<1.36 \mathrm{E}-04$ & & & & \\
\hline & Sample G438 & $<1.31 \mathrm{E}-04$ & & & & \\
\hline
\end{tabular}

Table A-3. Tank 241-AP-106 Analytical Data: Ruthenium/Rhodium-106

\begin{tabular}{|c|c|c|c|c|c|c|}
\hline Analyte & $\begin{array}{l}\text { Laboratory } \\
\text { Sample } \\
\text { Identification }\end{array}$ & $\begin{array}{c}\text { Analytical } \\
\text { Data } \\
\text { Result }\end{array}$ & $\begin{array}{c}\text { Range } \\
\text { of } \\
\text { Values }\end{array}$ & $\begin{array}{c}\text { Largest } \\
\text { Detection } \\
\text { Limit }\end{array}$ & $\begin{array}{l}\text { Standard } \\
\text { Deviation }\end{array}$ & $\begin{array}{l}\text { Projected } \\
\text { Inventory }\end{array}$ \\
\hline Radionuclide & & $\mu \mathrm{Ci} / \mathrm{mL}$ & $\mu \mathrm{Ci} / \mathrm{mL}$ & $\mu \mathrm{Ci} / \mathrm{mL}$ & $\mu \mathrm{Ci} / \mathrm{mL}$ & $\mathrm{Ci}$ \\
\hline \multirow[t]{8}{*}{ GEA. ${ }^{106} \mathrm{Ru} / \mathrm{Rh}$} & $\begin{array}{c}\text { Composite } \\
\text { Sample } \text { G386 }\end{array}$ & $<0.0552$ & \multirow{8}{*}{$\begin{array}{c}<0.0195 \\
\text { to } \\
<0.0636\end{array}$} & \multirow[t]{8}{*}{$<0.0636$} & \multirow[t]{8}{*}{ N/A } & \multirow[t]{8}{*}{$<272$} \\
\hline & Sample G423 & $<0.0480$ & & & & \\
\hline & Sample G427 & $<0.0195$ & & & & \\
\hline & Sample G428 & $<0.0508$ & & & & \\
\hline & Sample G432 & $<0.0636$ & & & & \\
\hline & Sample G433 & $<0.0497$ & & & & \\
\hline & Sample G437 & $<0.0356$ & & & & \\
\hline & Sample G438 & $<0.0353$ & & & & \\
\hline
\end{tabular}


Table A-3. Tank 241-AP-106 Analytical Data: Strontium-90

\begin{tabular}{|c|c|c|c|c|c|c|}
\hline Analyte & $\begin{array}{c}\text { Laboratory } \\
\text { Sample } \\
\text { Identification }\end{array}$ & $\begin{array}{l}\text { Analytical } \\
\text { Data } \\
\text { Result. }\end{array}$ & $\begin{array}{c}\text { Range } \\
\text { of } \\
\text { Valites }\end{array}$ & $\begin{array}{l}\text { Statistical } \\
\text { Mean }\end{array}$ & $\begin{array}{c}\text { Standard } \\
\text { Error }\end{array}$ & $\begin{array}{l}\text { Projected } \\
\text { Inventory }\end{array}$ \\
\hline Radionuclide & & $\mu \mathrm{Ci} / \mathrm{mL}$ & $\mu \mathrm{Ci} / \mathrm{mL}$ & $\mu \mathrm{Ci} / \mathrm{mL}$ & $\mu \mathrm{Ci} / \mathrm{mL}$ & $\mathrm{Ci}$ \\
\hline \multirow[t]{8}{*}{$\mathrm{BPC} .{ }^{90} \mathrm{Sr}$} & $\begin{array}{c}\text { Composite } \\
\text { Sample G386 }\end{array}$ & 5.57E-05 & \multirow{8}{*}{$\begin{array}{c}5.57 E-05 \\
\text { to } \\
2.81 E-03\end{array}$} & \multirow[t]{8}{*}{$6.98 E-04$} & \multirow[t]{8}{*}{$5.61 E-04$} & \multirow[t]{8}{*}{2.98} \\
\hline & Sample G423 & 2.81E-03 & & & & \\
\hline & Sample G427 & $9.03 E-04$ & & & & \\
\hline & Sample G428 & 7.4OE-05 & & & & \\
\hline & Sample G432 & $1.04 E-04$ & & & & \\
\hline & Sample G433 & $2.24 E-04$ & & & & \\
\hline & Sample G437 & $1.83 E-04$ & & & & \\
\hline & Sample G438 & 5.71E-05 & & & & \\
\hline
\end{tabular}

Table A-3. Tank 241-AP-106 Analytical Data: Technetium-99

\begin{tabular}{|c|c|c|c|c|c|c|}
\hline Analyte & $\begin{array}{l}\text { Laboratory } \\
\text { Sample } \\
\text { Identification }\end{array}$ & $\begin{array}{c}\text { Analytical } \\
\text { Data } \\
\text { Result }\end{array}$ & $\begin{array}{c}\text { Range } \\
\text { of } \\
\text { Values }\end{array}$ & $\begin{array}{c}\text { Statistical } \\
\text { Mean }\end{array}$ & $\begin{array}{l}\text { Standard } \\
\text { Error }\end{array}$ & $\begin{array}{l}\text { Projected } \\
\text { Inventory }\end{array}$ \\
\hline Radionuclide & & $\mu \mathrm{Ci} / \mathrm{mL}$ & $\mu \mathrm{Ci} / \mathrm{mL}$ & $\mu \mathrm{Ci} / \mathrm{mL}$ & $\mu \mathrm{Ci} / \mathrm{mL}$ & $\mathrm{Ci}$ \\
\hline \multirow[t]{8}{*}{ LSC. ${ }^{99} \mathrm{TC}$} & $\begin{array}{c}\text { Composite } \\
\text { Sample G386 }\end{array}$ & $1.40 \mathrm{E}-03$ & \multirow{8}{*}{$\begin{array}{c}1.13 \mathrm{E}-03 \\
\text { to } \\
1.61 \mathrm{E}-03\end{array}$} & \multirow[t]{8}{*}{$1.34 E-03$} & \multirow[t]{8}{*}{$7.64 \mathrm{E}-05$} & \multirow[t]{8}{*}{5.72} \\
\hline & Sample G423 & $<1.35 \mathrm{E}-03$ & & & & \\
\hline & Sample G427 & $1.18 E-03$ & & & & \\
\hline & Sample G428 & 1.61E-03 & & & & \\
\hline & Sample G432 & $1.26 \mathrm{E}-03$ & & & & \\
\hline & Sample G433 & $1.13 E-03$ & & & & \\
\hline & Sample G437 & $1.49 E-03$ & & & & \\
\hline & Sample 6438 & $1.23 E-03$ & & & & \\
\hline
\end{tabular}


Table A-3. Tank 241-AP-106 Analytical Data: Tritium

\begin{tabular}{|c|c|c|c|c|c|c|}
\hline $\begin{array}{r}\text { Analyte } \\
\therefore \\
\end{array}$ & $\begin{array}{c}\text { Laboratory } \\
\text { Sample } \\
\text { Identification }\end{array}$ & $\begin{array}{l}\text { Analytical } \\
\text { Data } \\
\text { Anesult }\end{array}$ & $\begin{array}{c}\text { Range } \\
\text { of } \\
\text { Values }\end{array}$ & $\begin{array}{c}\text { Evaluated } \\
\text { Ditä } \\
\text { Resuit }\end{array}$ & $\begin{array}{l}\text { Standard } \\
\text { Deviation }\end{array}$ & $\begin{array}{l}\text { Projected } \\
\text { Inventory }\end{array}$ \\
\hline Radionuclide & & $\mu \mathrm{Ci} / \mathrm{mL}$ & $\mu \mathrm{Ci} / \mathrm{mL}$ & $\mu \mathrm{Ci} / \mathrm{mL}$ & $\mu \mathrm{Ci} / \mathrm{mL}$ & $\mathrm{Ci}$ \\
\hline LSC. ${ }^{3} \mathrm{H}$ & $\begin{array}{c}\text { Composite } \\
\text { Sample G386 }\end{array}$ & 0.0049 & N/A & 0.0049 & N/A & 20.9 \\
\hline
\end{tabular}

Table A-4. Tank 241-AP-106 Analytical Data: EDTA

\begin{tabular}{|c|c|c|c|c|c|c|}
\hline Analyte & $\begin{array}{c}\text { Laboratory } \\
\text { Sample } \\
\text { Identification }\end{array}$ & $\begin{array}{c}\text { Analytical } \\
\text { Data } \\
\text { Result }\end{array}$ & $\begin{array}{c}\text { Range } \\
\text { of } \\
\text { Values }\end{array}$ & $\begin{array}{c}\text { Largest } \\
\text { Detection } \\
\text { Limit }\end{array}$ & $\begin{array}{l}\text { Standard } \\
\text { Deviation }\end{array}$ & $\begin{array}{l}\text { Projected } \\
\text { Inventory }\end{array}$ \\
\hline Organic & & $\mathrm{mg} / \mathrm{L}$ & $\mathrm{mg} / \mathrm{L}$ & $\mathrm{mg} / \mathrm{L}$ & $\mathrm{mg} / \mathrm{L}$ & $\mathrm{kg}$ \\
\hline \multirow[t]{7}{*}{ HPLC. EDTA } & Sample G257 & $<20$ & \multirow[t]{7}{*}{ N/A } & \multirow[t]{7}{*}{$<20$} & \multirow[t]{7}{*}{ N/A } & \multirow[t]{7}{*}{$<85.40$} \\
\hline & Sample G259 & $<20$ & & & & \\
\hline & Sample G261 & $<20$ & & & & \\
\hline & Sample G263 & $<20$ & & & & \\
\hline & Sample G265 & $<20$ & & & & \\
\hline & Sample G266 & $<20$ & & & & \\
\hline & Sample G268 & $<20$ & & & & \\
\hline
\end{tabular}

Table A-4. Tank 241-AP-106 Analytical Data: HEDTA

\begin{tabular}{|c|c|c|c|c|c|c|}
\hline Analyte & $\begin{array}{l}\text { Laboratory } \\
\text { Sample } \\
\text { Identification }\end{array}$ & $\begin{array}{c}\text { Analytical } \\
\text { Data } \\
\text { Result }\end{array}$ & $\begin{array}{c}\text { Range } \\
\text { of } \\
\text { Values }\end{array}$ & $\begin{array}{c}\text { Largest } \\
\text { Detection } \\
\text { Limit }\end{array}$ & $\begin{array}{l}\text { Standard } \\
\text { Deviation }\end{array}$ & $\begin{array}{l}\text { Projected } \\
\text { Inventory }\end{array}$ \\
\hline Organic & & $\mathrm{mg} / \mathrm{L}$ & $\mathrm{mg} / \mathrm{L}$ & $\mathrm{mg} / \mathrm{L}$ & $\mathrm{mg} / \mathrm{L}$ & $\mathrm{kg}$ \\
\hline \multirow[t]{7}{*}{ HPLC. HEDTA } & Sample G257 & $<20$ & \multirow[t]{7}{*}{ N/A } & \multirow[t]{7}{*}{$<20$} & \multirow[t]{7}{*}{ N/A } & \multirow[t]{7}{*}{$<85.40$} \\
\hline & Sample G259 & $<20$ & & & & \\
\hline & Sample G261 & $<20$ & & & & \\
\hline & Sample G263 & $<20$ & & & & \\
\hline & Sample G265 & $<20$ & & & & \\
\hline & Sample G266 & $<20$ & & & & \\
\hline & Sample G268 & $<20$ & & & & \\
\hline
\end{tabular}


Table A-4. Tank 241-AP-106 Analytical Data: Citrate

\begin{tabular}{|c|c|c|c|c|c|c|}
\hline Analyte & $\begin{array}{l}\text { Laboratory } \\
\text { Sample } \\
\text { Identification }\end{array}$ & $\begin{array}{c}\text { Analytical } \\
\text { Data } \\
\text { Result }\end{array}$ & $\begin{array}{c}\text { Range } \\
\text { of } \\
\text { Values }\end{array}$ & $\begin{array}{l}\text { Largest } \\
\text { Detection } \\
\text { Limit }\end{array}$ & $\begin{array}{l}\text { Standard } \\
\text { Deviation }\end{array}$ & $\begin{array}{l}\text { Projected } \\
\text { Inventory }\end{array}$ \\
\hline Organic & & $\mathrm{mg} / \mathrm{L}$ & $\mathrm{mg} / \mathrm{L}$ & $\mathrm{mg} / \mathrm{L}$ & $\mathrm{mg} / \mathrm{L}$ & $\mathrm{kg}$ \\
\hline \multirow{7}{*}{$\begin{array}{l}\text { HPLC. } \\
\text { Citrate }\end{array}$} & Sample G257 & $<44$ & \multirow[t]{7}{*}{ N/A } & \multirow[t]{7}{*}{$<44$} & \multirow[t]{7}{*}{ N/A } & \multirow[t]{7}{*}{$<188$} \\
\hline & Sample G259 & $<44$ & & & & \\
\hline & Sample G261 & $<44$ & & & & \\
\hline & Sample G263 & $<44$ & & & & \\
\hline & Sample G265 & $<44$ & & & & \\
\hline & Sample G266 & $<44$ & & & & \\
\hline & Sample G268 & $<44$ & & & & \\
\hline
\end{tabular}

Table A-4. Tank 241-AP-106 Analytical Data: Glycolate

\begin{tabular}{|c|c|c|c|c|c|c|}
\hline Analyte & $\begin{array}{c}\text { Laboratory } \\
\text { Sample } \\
\text { Identification }\end{array}$ & $\begin{array}{c}\text { Analytical } \\
\text { Data } \\
\text { Result }\end{array}$ & $\begin{array}{c}\text { Pange } \\
\text { of } \\
\text { Values }\end{array}$ & $\begin{array}{c}\text { Evaluated } \\
\text { Data } \\
\text { Result }\end{array}$ & $\begin{array}{l}\text { Standard } \\
\text { Deviation }\end{array}$ & $\begin{array}{l}\text { Projected } \\
\text { Inventory }\end{array}$ \\
\hline Organic & & $\mathrm{mg} / \mathrm{L}$ & $\mathrm{mg} / \mathrm{L}$ & $\mathrm{mg} / \mathrm{L}$ & $\mathrm{mg} / \mathrm{L}$ & $\mathrm{kg}$ \\
\hline \multirow[t]{7}{*}{ LC. Glycolate } & Sample G257 & 50.00 & \multirow{7}{*}{$\begin{array}{l}50 \\
\text { to } \\
90\end{array}$} & \multirow[t]{7}{*}{64.30} & \multirow[t]{7}{*}{5.70} & \multirow[t]{7}{*}{275} \\
\hline & Sample G259 & 50.00 & & & & \\
\hline & Sample G261 & 90.00 & & & & \\
\hline & Sample G263 & 60.00 & & & & \\
\hline & Sample G265 & 70.00 & & & & \\
\hline & Sample G266 & 70.00 & & & & \\
\hline & Sample G268 & 60.00 & & & & \\
\hline
\end{tabular}


Table A-4. Tank 241-AP-106 Analytical Data: Oxalate

\begin{tabular}{|c|c|c|c|c|c|c|}
\hline Analyte & $\begin{array}{l}\text { Laboratory } \\
\text { Sample } \\
\text { Identifitication }\end{array}$ & $\begin{array}{c}\text { Analytical } \\
\text { Data } \\
\text { Result }\end{array}$ & $\begin{array}{c}\text { Range } \\
\text { of } \\
\text { Valües }\end{array}$ & $\begin{array}{l}\text { Evaluated } \\
\text { Data } \\
\text { Result }\end{array}$ & $\begin{array}{l}\text { Standard } \\
\text { Deviation }\end{array}$ & $\begin{array}{l}\text { Projected } \\
\text { Inventory }\end{array}$ \\
\hline Organic & & $\mathrm{mg} / \mathrm{L}$ & $\mathrm{mg} / \mathrm{L}$ & $\mathrm{mg} / \mathrm{L}$ & $\mathrm{mg} / \mathrm{L}$ & $\mathrm{kg}$ \\
\hline \multirow[t]{7}{*}{ LC. Oxalate } & Sample G257 & 80.00 & \multirow{7}{*}{$\begin{array}{l}70 \\
\text { to } \\
90\end{array}$} & \multirow[t]{7}{*}{75.7} & \multirow[t]{7}{*}{3.21} & \multirow[t]{7}{*}{323} \\
\hline & Sample G259 & 70.00 & & & & \\
\hline & Sample G261 & 80.00 & & & & \\
\hline & Sample G263 & 70.00 & & & & \\
\hline & Sample G265 & 70.00 & & & & \\
\hline & Sample G266 & 70.00 & & & & \\
\hline & Sample G268 & 90.00 & & & & \\
\hline
\end{tabular}

Table A-5. Tank 241-AP-106 Analytical Data: Percent Water

\begin{tabular}{|c|c|c|c|c|c|c|}
\hline Analyte & $\begin{array}{l}\text { Laboratory } \\
\text { Sample } \\
\text { Identification }\end{array}$ & $\begin{array}{l}\text { Analytical } \\
\text { Data } \\
\text { Result }\end{array}$ & $\begin{array}{l}\text { Range } \\
\text { of } \\
\text { Values }\end{array}$ & $\begin{array}{c}\text { Statistical } \\
\text { Mean }\end{array}$ & $\begin{array}{l}\text { Standard } \\
\text { Error }\end{array}$ & $\begin{array}{l}\text { Projected } \\
\text { Inventory }\end{array}$ \\
\hline $\begin{array}{l}\text { Physical } \\
\text { Property }\end{array}$ & & $\%$ & $\%$ & $\%$ & $\%$ & \\
\hline \multirow[t]{8}{*}{ TGA. \% H2O } & $\begin{array}{c}\text { Composite } \\
\text { Sample G386 }\end{array}$ & 99.3 & \multirow{8}{*}{$\begin{array}{l}99.3 \\
\text { to } \\
99.8\end{array}$} & \multirow[t]{8}{*}{100.2} & \multirow[t]{8}{*}{0.400} & \multirow[t]{8}{*}{ N/A } \\
\hline & Sample G423 & 99.7 & & & & \\
\hline & Sample G427 & 99.8 & & & & \\
\hline & Sample G428 & 103 & & & & \\
\hline & Sample G432 & 99.8 & & & & \\
\hline & Sample G433 & 99.8 & & & & \\
\hline & Sample G437 & 99.6 & & & & \\
\hline & Sample G438 & 99.8 & & & & \\
\hline
\end{tabular}


Table A-5. Tank 241-AP-106 Analytical Data: Specific Gravity

\begin{tabular}{|c|c|c|c|c|c|c|}
\hline Analyte & $\begin{array}{c}\text { Laboratory } \\
\text { Sample } \\
\text { Identification }\end{array}$ & $\begin{array}{l}\text { Analytical } \\
\text { Data } \\
\text { Result }\end{array}$ & $\begin{array}{c}\text { Range } \\
\text { of } \\
\text { Values }\end{array}$ & $\begin{array}{c}\text { Statistical } \\
\text { Mean }\end{array}$ & $\begin{array}{l}\text { Standard } \\
\text { Error }\end{array}$ & $\begin{array}{l}\text { Projected } \\
\text { Inventory }\end{array}$ \\
\hline \multicolumn{7}{|l|}{$\begin{array}{l}\text { Physical } \\
\text { Property }\end{array}$} \\
\hline \multirow[t]{8}{*}{ DM.SpG } & $\begin{array}{c}\text { Composite } \\
\text { Sample G386 }\end{array}$ & 0.997 & \multirow{8}{*}{$\begin{array}{c}0.993 \\
\text { to } \\
1.000\end{array}$} & \multirow[t]{8}{*}{0.996} & \multirow[t]{8}{*}{$9.10 \mathrm{E}-04$} & \multirow[t]{8}{*}{ N/A } \\
\hline & Sample G423 & 0.997 & & & & \\
\hline & Sample G427 & 0.998 & & & & \\
\hline & Sample G428 & 1.000 & & & & \\
\hline & Sample G432 & 0.996 & & & & \\
\hline & Sample G433 & 0.997 & & & & \\
\hline & Sample G437 & 0.993 & & & & \\
\hline & Sample G438 & 0.994 & & & & \\
\hline
\end{tabular}

Table A-5. Tank 241-AP-106 Analytical Data: Total Inorganic Carbon

\begin{tabular}{|c|c|c|c|c|c|c|}
\hline Analyte & $\begin{array}{l}\text { Laboratory } \\
\text { Sample } \\
\text { Identification }\end{array}$ & $\begin{array}{c}\text { Analytical } \\
\text { Data } \\
\text { Result }\end{array}$ & $\begin{array}{c}\text { Range } \\
\text { of } \\
\text { Values }\end{array}$ & $\begin{array}{c}\text { Statistical } \\
\text { Mean }\end{array}$ & $\begin{array}{l}\text { Standard } \\
\text { Error }\end{array}$ & $\begin{array}{l}\text { Projected } \\
\text { Inventory }\end{array}$ \\
\hline $\begin{array}{l}\text { Physical } \\
\text { Property }\end{array}$ & & $\mu \mathrm{g} / \mathrm{mL}$ & $\mu \mathrm{g} / \mathrm{mL}$ & $\mu \mathrm{g} / \mathrm{mL}$ & $\mu \mathrm{g} / \mathrm{mL}$ & $\mathrm{kg}$ \\
\hline \multirow[t]{7}{*}{ Coul. TIC } & Sample G423 & 525 & \multirow{7}{*}{$\begin{array}{l}422 \\
\text { to } \\
589\end{array}$} & \multirow[t]{7}{*}{486} & \multirow[t]{7}{*}{17.6} & \multirow[t]{7}{*}{2,080} \\
\hline & Sample G427 & 529 & & & & \\
\hline & Sample G428 & 442 & & & & \\
\hline & ample G432 & 517 & & & & \\
\hline & Sample G433 & 412 & & & & \\
\hline & Sample G437 & 467 & & & & \\
\hline & Sample G438 & 491 & & & & \\
\hline
\end{tabular}


Table A-5. Tank 241-AP-106 Analytical Data: Total Organic Carbon

\begin{tabular}{|c|c|c|c|c|c|c|}
\hline $\begin{array}{c}\text { Analyte } \\
\ldots\end{array}$ & $\begin{array}{c}\text { Laboratory } \\
\text { Sample } \\
\text { Identification }\end{array}$ & $\begin{array}{c}\text { Analytical } \\
\text { Data } \\
\text { Result }\end{array}$ & $\begin{array}{l}\text { Range } \\
\text { of } \\
\text { Values }\end{array}$ & $\begin{array}{l}\text { Statistical } \\
\text { Mean }\end{array}$ & $\begin{array}{l}\text { Standard } \\
\text { Error }\end{array}$ & $\begin{array}{l}\text { Projected } \\
\text { Inventory }\end{array}$ \\
\hline $\begin{array}{l}\text { Physical } \\
\text { Property }\end{array}$ & & $\mu \mathrm{g} / \mathrm{mL}$ & $\mu \mathrm{g} / \mathrm{mL}$ & $\mu \mathrm{g} / \mathrm{mL}$ & $\mu \mathrm{g} / \mathrm{mL}$ & kg \\
\hline \multirow[t]{8}{*}{ COUL. TOC } & $\begin{array}{c}\text { Composite } \\
\text { Sample G386 }\end{array}$ & 536 & \multirow{8}{*}{$\begin{array}{l}449 \\
\text { to } \\
652\end{array}$} & \multirow[t]{8}{*}{497} & \multirow[t]{8}{*}{15.7} & \multirow[t]{8}{*}{2,120} \\
\hline & Sample G423 & 555 & & & & \\
\hline & Sample G427 & 506 & & & & \\
\hline & Sample G428 & 496 & & & & \\
\hline & Sample G432 & 552 & & & & \\
\hline & Sample G433 & 484 & & & & \\
\hline & Sample G437 & 462 & & & & \\
\hline & Sample G438 & 449 & & & & \\
\hline
\end{tabular}

Table A-6. Tank 241-AP-106 Analytical Data: Volatile Organic Compounds

\begin{tabular}{|c|c|c|c|}
\hline Analyte & $\begin{array}{c}\text { Detection } \\
\text { Limit }\end{array}$ & Analyte & $\begin{array}{c}\text { Detection } \\
\text { Limit }\end{array}$ \\
\hline Vinyl Chloride & ND & 4-Methyl-2-Pentanone & ND \\
\hline Methylene Chloride & ND & Tetrachloroethane & ND \\
\hline Acetone & ND & $1,1,2,2$-Tetrachloroethane & ND \\
\hline Carbon Disulfide & ND & Toluene & ND \\
\hline 1,1-Dichloroethene & ND & Chlorobenzene & ND \\
\hline Chloroform & ND & Ethylbenzene & ND \\
\hline 1.2-Dichloroethane & ND & m\&p-Xylene & ND \\
\hline 2-Butanone & ND & o-Xylene & ND \\
\hline $1,1,1$-Trichloroethane & ND & Isopropylbenzene & ND \\
\hline Carbon Tetrachloride & ND & 1,3,5-Trimethylbenzene & ND \\
\hline Trichloroethane & ND & 1,2,4-Trimethylbenzene & ND \\
\hline 1,1,2-Trichloroethane & ND & 1,2,3-Trimethylbenzene & ND \\
\hline Benzene & ND & & \\
\hline
\end{tabular}

NOTE: All VOA analysis results were <CRQL. Acetone was found in sample $\mathrm{G} 261$ at a minimum <CRQL $(450 \mu \mathrm{g} / \mathrm{L})$. The result was qualified as estimated. Acetone is a common laboratory contaminant and not a likely waste constituent (see Section 5). 
Table A-6. Tank 241-AP-106 Analytical Data: Semivolatile Organic Compounds

\begin{tabular}{|c|c|c|c|}
\hline Analyte & $\begin{array}{c}\text { Detection } \\
\text { Limit }\end{array}$ & Analyte & $\begin{array}{l}\text { Detection } \\
\text { Limit }\end{array}$ \\
\hline 1-Butanol & ND & 2,4,6-Trichlorophenol & ND \\
\hline Pyridine & ND & $2,4,5$-Trichlorophenol & ND \\
\hline 1,4-Dichlorobenzene & ND & 2,4-Dinitrotoluene & ND \\
\hline 1.2-Dichlorobenzene & ND & Diethylphthalate & ND \\
\hline 2-Methylphenol & ND & Tributylphosphate & ND \\
\hline 4-Methylphenol & ND & Hexachlorobenzene & ND \\
\hline Hexachloroethane & ND & Pentachlorophenol & ND \\
\hline Nitrobenzene & ND & Di-n-octylphthalate & ND \\
\hline Hexachlorobutadiene & ND & & \\
\hline
\end{tabular}

NOTE: No Semivolatile Target compounds were detected in the samples at levels $>$ CRQL. 